\title{
Supplementation of pig starter diets with carbohydrate-degrading enzymes - stability, activity and mode of action
}

\author{
JOHAN INBORR \\ University of Helsinki \\ Department of Animal Science \\ FIN-00014 University of Helsinki, Finland
}

Academic dissertation

To be presented, with the permission of the Faculty of Agriculture and Forestry of the University of Helsinki, for public criticism in the Small Hall, Fabianinkatu 33, Helsinki, on April 14th, 1994, at 10 am. 


\section{PREFACE}

This work is a result of an idea born within the Cultor Ltd. Group almost ten years ago. This idea developed into a concept, which was later introduced to the international scene, where it found a wide acceptance and gained momentum. Over the years, a large number animal nutritionists and biochemists have contributed to the development of this concept, simply called 'pig feed enzymes', to give it the credibility it enjoys today. To mention all these persons would be an impossible task, but in the following I have tried to list the ones that significantly contributed to this thesis.

First of all I want to thank Professor Liisa Syrjälä-Qvist, Department of Animal Science, University of Helsinki, for her positive attitude towards this work and Associate Professor Matti Näsi, at the same department for valuable critisism of the manuscripts and his encouragement.

I also wish to express my sincere gratitude to:

Dr Martin Schmitz and Dr Frank Ahrens at the IS Forschungsgesellschaft GmbH\&Co, Wahlstedt, Germany for invaluable assistance in conducting the slaughter experiment and with the statistical analysis of the data.

Dr Jan van der Meulen at the DLO Institute for Livestock Feeding and Nutrition, Lelystad, The Netherlands for supervising the cannulation experiment and analysing the data, and for valuable critisism of the manuscripts.

Dr Kirsten Jakobsen, Dr Knud Erik Bach Knudsen, Dr Bent Borg Jensen and Ms Mette Skou Jensen at the National Institute of Animal Science (NIAS), Foulum, Denmark for supervising the work at the institute and for the practical arrangements and the day-to-day care of the pigs, data collection and sample analysis.

Mr Walter Michie, Scottish Agricultural College in Aberdeen, Craibstone Poultry Research Unit, for arranging and supervising the broiler experiment.

Dr Mike Bedford at Finnfeeds International Ltd., Marlborough, United Kingdom, for his professional assistance with the statistical analysis of the data and valuable critisism of the manuscripts, and all my friends at Finnfeeds International Ltd. for support and encouragement during the course of the work.

Mr Jari Puhakka and Mrs Anne Grönlund at the Cultor Ltd. Technology Centre for arranging and supervising the enzyme activity analyses and for valuable assistance in preparing the manuscripts.

Mr Tom von Weymarn, Cultor Ltd., Helsinki, Finland, and Mr Richard Cooper, Finnfeeds International Ltd., for allowing the entire project to be carried out within the scope of Cultor Ltd. Animal Nutrition Group's and Finnfeeds International Ltd.'s Research and Development programmes.

And last but certainly not least I am forever greatful to the four most amiable ladies in the world, my wife Maggi and daughters Sara, Jennie and Ina for their never failing support and encouragement, and for being a source of inspiration during the course of this work.

The experiments included in this thesis were conducted during 1988-1993 as part of the research programme of Finnfeeds International Ltd., Marlborough, England.

Hamburg, 22nd December 1993

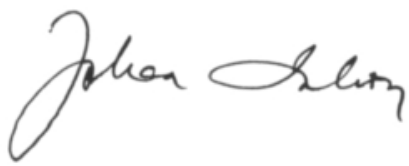




\section{LIST OF PUBLICATIONS}

This thesis is based on the following five papers which will be referred to by their Roman numerals:

I INBORR, J. \& BEDFORD, M.R. 1994. Stability of feed enzymes to steam pelleting during feed processing. Animal Feed Science and Technology (in press).

II INBORR, J. \& GRÖNLUND, A. 1992. Stability of feed enzymes in physiological conditions assayed by in vitro methods. Agricultural Science in Finland 2: 125-132.

III InborR, J., VAn der Meulen, J. \& PuhaKKa, J. 1993. Nutritional implications of feeding enzyme-treated wheat bran to pigs. 1. Recovery of added enzyme activities in the stomach and terminal ileum. Submitted to British Journal of Nutrition (Publisher: Cambridge University Press).

IV INBORR, J., SCHMITZ, M. \& AHRENS, F. 1993. Effect of adding fibre and starch-degrading enzymes to a barley/wheat based diet on performance and nutrient digestibility in different segments of the small intestine of early weaned pigs. Animal Feed Science and Technology 44: 113-127.

V INBORR, J. 1994. Gastrointestinal parameters influencing performance of pigs fed enzyme-supplemented barley-based feeds. Submitted to British Journal of Nutrition (Publisher: Cambridge University Press). 


\section{CONTENTS}

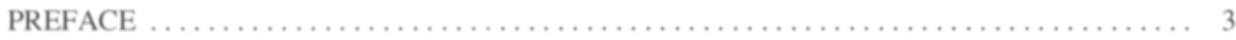

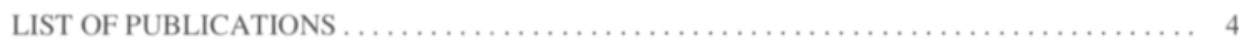

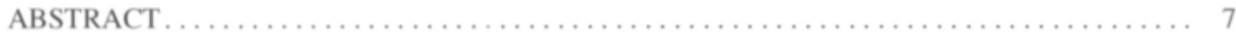

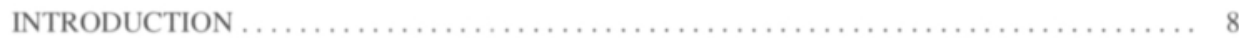

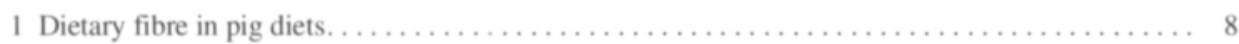

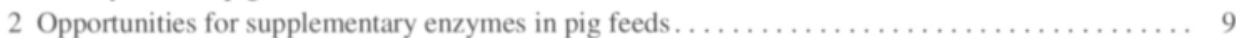

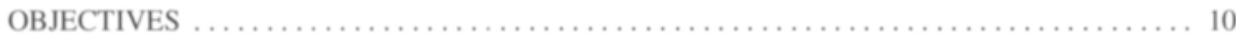

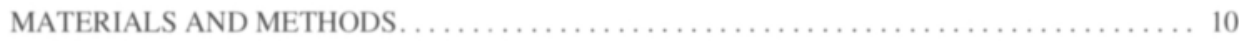

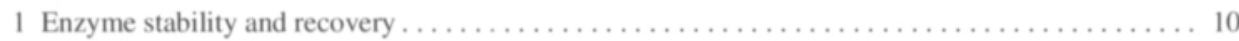

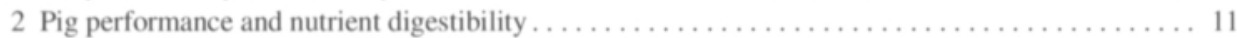

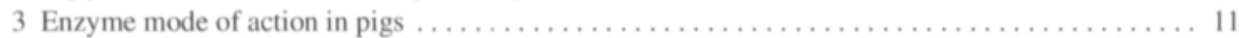

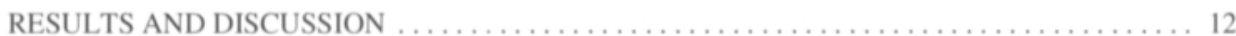

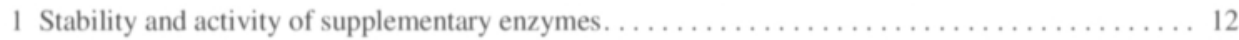

2 Site and mode of action of carbohydrate-degrading enzymes $\ldots \ldots \ldots \ldots \ldots \ldots \ldots \ldots \ldots \ldots \ldots \ldots$

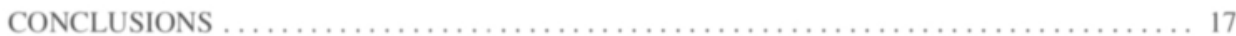

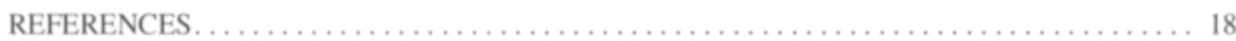

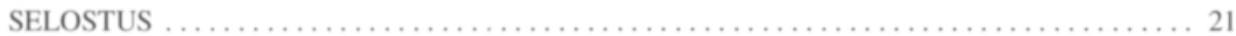

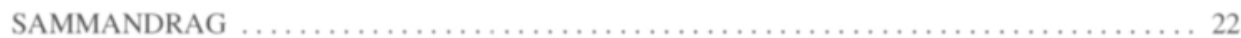

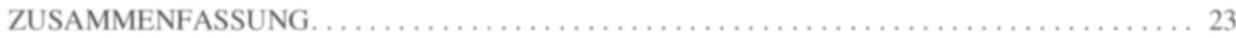

PUBLICATIONS I-V 


\title{
Supplementation of pig starter diets with carbohydrate-degrading enzymes - stability, activity and mode of action
}

\author{
JOHAN INBORR
}

INBORR, J. 1994. Supplementation of pig starter diets with carbohydrate-degrading enzymes - stability, activity and mode of action. Agricultural Science in Finland 3: Supplement No. 2. 23 p. Academic dissertation. (Department of Animal Science, P.O. Box 28, FIN-00014 University of Helsinki, Finland.)

A total of five experiments were conducted to investigate the stability of feed enzymes to steam pelleting and the proteolytic conditions in the gastrointestinal (GI) tract of pigs and poultry, and to try and elucidate the mechanisms behind the improved performance of pigs fed enzyme-supplemented barley/wheat-based diets.

The results of the pelleting stability experiment showed that the commercial feed enzyme employed maintained most of its activity in conditioning temperatures up to $85^{\circ} \mathrm{C}$. Furthermore, it became evident that measuring enzyme recovery in pelleted feeds by in-vitro assay methods underestimated the actual activity. For this purpose in-vivo models such as that based on gut viscosity measurements in broiler chickens gives a more accurate estimate. Gut viscosity also correlated highly with live weight gain $\left(r^{2}=0.624\right)$ and feed utilisation $\left(r^{2}=0.616\right)$ of broiler chickens. The in-vitro incubations using conditions similar to those of the GI tract showed that enzymes are not readily denatured and inactivated in such conditions and indicated that wheat and wheat gluten, and possibly similar feed ingredients, may help to maintain the activity longer either due to their buffering capacity or by providing substrates for the enzymes. This was supported by the results of the in-vivo measurements. In the stomach of pigs, 10-20 per cent of the xylanase and $\beta$-glucanase activities added to the diets could still be recovered 4 hours after feeding. In the ileum, proportionally more added enzyme activities were recovered between 4 and 6 than 0 and 2 hours after feeding. In broiler chickens fed an enzyme-supplemented barley-based diet, $\beta$-glucanase was fully recovered in the proximal part of the small intestine, giving further proof of the stability of the enzymes employed to the conditions of the GI tract.

When a mixture of fibre- and starch-degrading enzymes were added to a diet based on wheat and barley, $\beta$-glucan, starch and dry matter digestibilities were significantly $(\mathrm{P}<0.05)$ improved in the last quarter of the small intestine of early-weaned pigs but did not translate into improved growth or feed utilisation. However, the results showed that enzyme supplementation increased the rate of digestion and more nutrients were absorbed higher up in the small intestine. In a similarly designed experiment, adding a single $\beta$-glucanase preparation to diets based on either a low- or a high- $\beta$-glucan barley, improved live weight gain $(\mathrm{P}=0.074)$ and feed utilisation $(\mathrm{P}=0.058)$ of early-weaned pigs over a three-week experimental period. Although there was no significant improvement in nutrient digestibility, enzyme supplementation reduced digesta viscosity $(\mathrm{P}<0.03)$ and the concentration of digestive enzymes $(\mathrm{P}<0.08)$ in the three proximal quarters of the small intestine. Thus it appears that conditions for a more efficient digestion were brought about due to the reduction of digesta viscosity, enabling less production of pancreatic enzymes without affecting digestibility. Further analysis of the digesta samples showed a significant $(\mathrm{P}=0.044)$ reduction in the concentration of VFAs in the distal small intestine and hind gut of the pigs fed the enzyme-supplemented diets. This further indicates that enzyme supplementation leads to fewer nutrients escaping digestion and absorption in the small intestine such that less readily fermentable material was available for microbial growth. 
It is concluded that appropriately selected fibre- and starch-degrading enzymes added to pig starter diets based on wheat and barley exert their activity in the GI tract by reducing digesta viscosity and thereby increasing the efficiency and rate of digestion. Less digestive enzymes are needed and a greater portion of the nutrients are absorbed in the upper part of the small intestine. This leads to reduced microbial activity in the distal parts of the digestive tract, resulting in less fermentation losses and digestive upsets. All these effects contribute to overall improved performance of the pigs.

Key words: barley, wheat, $\beta$-glucan, viscosity, $\beta$-glucanase, xylanase, amylase, digestion, microbial fermentation

\section{INTRODUCTION}

\section{Dietary fibre in pig diets}

By definition, pigs like other monogastric animals are not capable of digesting dietary fibre (DF) by means of their own digestive enzymes (TROWELL et al. 1976). Since the concentration of DF in barley and wheat can be as high as 14 and $25 \%$ respectively ( $\mathrm{MAN} 1987$ ), a significant proportion of diets based on these cereal grains is usually poorly utilised by the pig.

Dietary fibre is composed of a very heterogenous mixture of substances, mainly associated with plant cell walls, which may be defined as non-starch polysaccharides (NSP) and lignin. Due to its complex physical and chemical characteristics, DF can influence many processes and reactions in the digestive system of the pig, thus influencing the utilisation of feed. Some of these effects were extensively reviewed by Low (1985).

Apart from lignin, which is an aromatic polymer of phenolic alcohols, DF consists of a wide range of polymers such as cellulose, hemicellulose, $\beta$-glucans, pentosans (arabinoxylans), pectic substances and oligosaccharides (raffinose and stachyose). It has also been proposed that certain types of processed starch that escape digestion by the host amylases, so called 'resistant starch', should be included in DF (ENGLYST and CUMMINGS 1985). Nine monosaccharides dominate quantitatively as the building blocks of fibre polysaccharides. These are the pentoses (xylose and arabinose), the hexoses (glucose, mannose and galactose), the 6-deoxyhexoses (rhamnose and fucose), and the hexauronic acids (galacturonic and glucuronic acid) (GRAHAM 1988).

The physical properties of DF are very much dependent upon their source and composition. Nevertheless, the ability to hold water seem to be a feature common to most DF sources. However, the extent of the water holding capacity varies significantly between sources and depends on the source of fibre, maturity of the plant, processing, particle size, $\mathrm{pH}$ and electrolyte composition. Many of these substances also tend to increase the viscosity of feeds when soaked (CHERBUT et al. 1990) and gut contents (MEYER et al. 1986, POTKINS et al. 1991, RoBERTS et al. 1990), which can influence the rate of gastric emptying (MEYER et al. 1986, RAINBIRD and LOW 1986), feed transit time (CHERBUT et al. 1990) and digestive secretions (IKEGAMI et al. 1990). In particular, nitrogen secretion seems to increase with increased amounts of dietary fibre, an observation made with both insoluble and soluble types of dietary fibre (ZEBROWSKA and LOW 1987, LANGLOIS et al. 1987). The apparent digestibility of nitrogen may thus be a function not only of the inherent digestibility of the dietary protein, but also of the type and amount of dietary fibre with which it is incorporated in the diet.

Nutrient absorption in the small intestine tend to 
be impaired at higher levels of DF. JUST et al. (1983) measured decreased apparent ileal digestibilities of nitrogen and fat as the crude fibre content increased from 33 to $161 \mathrm{~g} / \mathrm{kg}$ in diets fed to growing pigs. The most striking effect, however, was seen in the digestibility of energy.

Once DF leaves the small intestine its role as an agent which influence the digestion and absorption of other nutrients changes to that of being a nutrient in its own right, as a result of microbial fermentation. Again the type and amount of dietary fibre will influence the extent of this fermentation, which appears to be most intensive in the caecum and colon (BACH KNUDSEN et al. 1991). Microbial fermentation of fibre also occurs in the small intestine and the magnitude of this 'digestion' increases with age. GRAHAM et al. (1988a) reported the digestibility of fibre polysaccharides in 20,40 and $80 \mathrm{~kg}$ pigs to be 12,35 and $57 \%$, respectively, at the end of ileum. The end products of the fermentation of dietary fibre are the volatile fatty acids (VFA). These are absorbed through the gut wall into the portal blood and contribute to the total energy yield from the feed (ARGENZIO 1982). However, the magnitude of this contribution in relation to the total energy supply is a matter of debate (GoODLAD and MATHERS 1991) but has been estimated to be approximately 30 per cent of the energy requirement for maintenence in growing pigs (RERAT et al. 1987, YEN et al. 1991). Some chemical and physical properties of DF in relation to nutrition are presented in Table 1.

\section{Opportunities for supplementary enzymes in pig feeds}

Based on the above it would seem that adding fibre-degrading enzymes to diets with high concentration of DF could alleviate some of the anti-nutritive effects. Such enzymes are today available at relatively low cost and their use would, therefore, appear more attractive than in the past. In fact, enzyme supplementation of pig feeds has attracted increasing interest in recent years although the results have been fairly inconsistent compared to those obtained with broiler chickens (CHESSON
Table 1. The fibre properties implicated, and some of the possible mechanisms involved in the modification at varoius stages of nutrient assimilation in pigs (GRAHAM 1988).

\begin{tabular}{|c|c|c|}
\hline $\begin{array}{l}\text { Stage of } \\
\text { assimilation }\end{array}$ & $\begin{array}{l}\text { Fiber properties } \\
\text { implicated }\end{array}$ & $\begin{array}{l}\text { Possible } \\
\text { mechanisms } \\
\text { involved }\end{array}$ \\
\hline Intake & $\begin{array}{l}\text { Bulk } \\
\text { Water-binding capacity } \\
\text { Energy dilution }\end{array}$ & $\begin{array}{l}\text { Mechanical } \\
\text { Viscosity } \\
\text { Taste } \\
\text { Hormonal }\end{array}$ \\
\hline Passage rate & $\begin{array}{l}\text { Bulk } \\
\text { Water-binding capacity }\end{array}$ & $\begin{array}{l}\text { Mechanical } \\
\text { Viscosity } \\
\text { Hormonal }\end{array}$ \\
\hline $\begin{array}{l}\text { Enzyme hydrolysis } \\
\text { and absorption }\end{array}$ & $\begin{array}{l}\text { Water-binding capacity } \\
\text { Cation-exchange capacity } \\
\text { Architecture } \\
\text { Hydrophobicity }\end{array}$ & $\begin{array}{l}\text { Viscosity } \\
\text { Adsorption } \\
\text { Hormonal }\end{array}$ \\
\hline $\begin{array}{l}\text { Bacterial } \\
\text { fermentation }\end{array}$ & $\begin{array}{l}\text { Cell wall composition } \\
\text { and structure }\end{array}$ & $\begin{array}{l}\text { Potential } \\
\text { degradation } \\
\text { Transit time }\end{array}$ \\
\hline
\end{tabular}

1987, DIERICK 1989). Hence in many experiments supplementation of barley-based diets with $\beta$-glucanases (cellulases) has improved pig performance (THOMKE et al. 1980, NEWMAN et al. 1983, MARKSTRÖM et al. 1985), increased ileal (GRAHAM et al. 1988b, BEDFORD et al. 1992) and faecal (GRAHAM et al. 1988b, INBORR and GRAHAM 1991) nutrient digestibility and reduced the incidence of digestive upsets (INBORR and OGLE 1988, BÖHME 1990). However, there are also reports of non-significant responses to $\beta$-glucanase supplementation of barley-based diets (NEWMAN et al. 1980, GRAHAM et al. 1986). Enzyme treatment of other types of diets or raw materials such as soybean and rapeseed meal (NÄSI 1991), rye (BURACZEWSKA 1988, THACKER et al. 1992) and wheat (McCLEAN et al. 1993) has sometimes met with success. However, TANGENDJAJA et al. (1988) failed to improve the nutritive value of rice bran to pigs by cellulase treatment. It should be noted that more consistent positive reponses to enzyme supplementation have been obtained with young pigs in the post-weaning period up to $25 \mathrm{~kg}$ liveweight than with growing/finishing pigs. 
One explanation to the inconsistent responses to enzyme supplementation of pig feeds may be found in the stability and activity of the enzymes employed. If for any reason the enzymes employed cannot exert their activity at the expected site of action, no physiological response can be expected. Being proteins, possessing very specific features both in terms of their structure and mode of action, enzymes are susceptible to, for example, changes in $\mathrm{pH}$, temperature and metal ion concentration, which can result in partial or total inactivation (GODFREY and REICHELT 1983). Heat-treatment of feeds and employing enzymes with inappropriate $\mathrm{pH}$ and temperature optima may, therefore, have contributed to the failure of many experiments in the past. Consequently, enzymes with proven stability and suitable $\mathrm{pH}$ and temperature optima need to be identified before initiating elaborate experiments.

In summary, based on the results cited above, there seems to be an opportunity for improving the nutritive value of raw materials with relatively high DF content by fibre-degrading enzymes. However, based on the information generated to date it is not possible to predict the magnitude of the response or explain the mode of action of supplementary enzymes in pig feeds. In broiler chickens, a reduction of digesta viscosity due to added enzymes has been shown to highly correlate with improved bird performance regardless of DF source (BEDFORD and Classen 1992, INBORR et al. 1993). This was not the case in early-weaned pigs fed hulless barley (INBORR et al. 1991). Digesta viscosity, therefore, does not seem to interfere with digestion to the same extent in the pig as it does in the chick. The mechanisms behind the improved performance and nutrient digestibility that have been reported in response to enzyme supplemenation of diets for early-weaned and growing pigs are likely to relate to factors such as feed passage rate, pancreatic secretion, plant cell wall degradation and changes in the activity of the microflora.

\section{OBJECTIVES}

The objectives of the investigations reported in this thesis were:

1. To investigate the stability of feed enzymes to steam pelleting;

2. To investigate the stability and activity of feed enzymes in physiological conditions by in-vitro and in-vivo methods;

3. To study the effect of adding fibre- and starchdegrading enzymes to diets based on barley and wheat on nutrient digestibility and growth performance of early-weaned pigs;

4. To try and explain the mechanisms involved in the enzyme-induced growth response and improved nutrient digestibility of early-weaned pigs fed diets based on barley.

Reference will be made to similar studies with broiler chickens for interspecies comparison.

\section{MATERIALS AND METHODS}

\section{Enzyme stability and recovery}

For the purpose of estimating the stability of enzymes in various conditions and through steam pel- leting both in-vitro (I, II) and in-vivo (I and III) methods were employed.

In experiment I, a barley-based broiler starter feed with and without added enzyme (Avizyme 
$\mathrm{SX}^{\circledR}$ ) was pelleted after conditioning at 75,85 and $95^{\circ} \mathrm{C}$ for either 30 seconds or 15 minutes. $\beta$-glucanase activity of the feeds was determined by a viscosimetric method to assess the degree of inactivation due to pelleting. The feeds were fed to dayold broiler chickens for 19 days to study the relative activity of the enzyme based on bird performance. On day 19 , four birds per treatment were sacrificed and the viscosity and $\beta$-glucanase activity of the digesta of the upper half of the small intestine measured. The results from the in-vitro ( $\beta$-glucanase in feed) and in-vivo (digesta viscosity and $\beta$-glucanase activity) enzyme activity measurements were then used for assessing the extent of enzyme survival and compared with bird performance.

In experiment II, a crude xylanase preparation and a commercially available feed enzyme product were subjected to conditions similar to those in the stomach and small intestine of pigs. The treatments comprised of incubation in low $\mathrm{pH}$ (2.5) with pepsin for 30 minutes with and without wheat gluten followed by incubation in neutral $\mathrm{pH}$ with pancreatin for 30 minutes. Recoveries of xylanase and $\beta$-xylosidase of the crude xylanase preparation and xylanase and $\beta$-glucanase of the commercial product were measured after each incubation by enzyme activity analysis methods based on the release of reducing sugars and di-nitro salicylic acid (DNS).

Experiment III was designed to measure enzyme recovery and rate and magnitude of enzyme inactivation in the stomach and ileum of growing pigs. Five pigs of approximately $31 \mathrm{~kg}$ live weight were fitted with cannulas in the stomach and terminal ileum and fed one of five diets over five 14-day periods in a 5 x 5 Latin Square design. The experimental diets were based on wheat bran $(40 \%)$ that had been either incubated $\left(3.5\right.$ hours at $\left.39^{\circ} \mathrm{C}\right)$ or supplemented with one of two crude enzyme preparations (one cellulase and one xylanase) prior to feeding. Wheat bran incubated without enzyme served as a control. Other main components of the experimental diets were maize starch $(49.3 \%)$ and casein $(8.2 \%)$. Samples of the stomach contents were taken immediately after feeding and then 2 and 4 hour after feeding, whereas ileal chyme was collected between 0 and 2, 2 and 4, and 4 and 6 hours after feeding. Xylanase and $\beta$-glucanase ac- tivities of the samples were measured by DNS methods using standard conditions $(\mathrm{pH}$, temperature, incubation time) or modified to actual sample $\mathrm{pH}$ and physiological temperature $\left(39^{\circ} \mathrm{C}\right)$ with a prolonged incubation time.

\section{Pig performance and nutrient digestibility}

A total of 96 pigs, weaned between 21 and 24 days of age, were divided into twelve groups of eight and housed in flat-deck pens for three weeks (experiment IV). A basal diet based on barley (35\%), wheat $(35 \%)$ and soybean meal $(22 \%)$ was used as a control or supplemented with either of two enzyme premixes containing $\beta$-glucanase, xylanase and $\alpha$-amylase. Titanium oxide was added as an indigestible marker. The diets were fed ad libitum for 21 days and liveweight gain and feed consumption recorded on a weekly basis. At the end of the experiment two pigs per pen were sacrificed, the small intestine removed and divided into four segments of equal length. Dry matter, protein, starch and fibre digestibilities were estimated in the three distal segments.

\section{Enzyme mode of action in pigs}

Forty pigs weaned at three weeks of age were housed individually in metabolism cages in blocks of eight animals (experiment V). There were two pigs per dietary treatment in each block with all pigs of the same replicate selected from the same litter. There were two basal diets, one based on a hulled (Arra) and one based on a hulless (Condor) barley cultivar. Each diet was supplemented with and without a $\beta$-glucanase preparation (Multifect $\mathrm{CS}^{\circledR}$, Genencor International Ltd., Helsinki, Finland) and fed ad libitum for 21 days. Liveweights and feed consumption were recorded weekly. On day 21 the pigs were slaughtered and the digestive tract removed and divided into the following segments: stomach (Sto), four sections of equal length of the small intestine (SI1-4), caecum (Cae), ascending (Co1) and descending (Co2) colon and 
rectum (Rec). The contents of each segment was collected quantitatively. Viscosity of the supernatant was measured directly after centrifugation of the fresh digesta samples. After freeze drying, samples were analysed for $\beta$-glucan and nutrient digest- ibility based on chromic oxide, which was used as an indigestible marker. In addition, the concentration of volatile fatty acids (VFA) was measured in the distal small intestine, caecum, colon and rectum.

\section{RESULTS AND DISCUSSION}

\section{Stability and activity of supplementary enzymes}

Based on the $\beta$-glucanase assay of the pelleted feed samples, enzyme activity decreased with increasing conditioning times and temperatures (Figure 1, I). A similar trend was observed in the digesta viscosity values, although to a lesser degree. These results would indicate that the assay method employed to measure the $\beta$-glucanase activity in feed underestimated the actual activity. This is probably due to the enzyme binding so strongly to its substrate that it cannot be fully extracted during the assay. Many cell wall degrading enzymes (cellulases, endohydrolases and cellobiohydrolases) have been found to possess a cellulose binding domain (CBD) with which they bind to cellulose (NIEVES et al. 1991, PoOLE et al. 1991). Despite being immobilised,

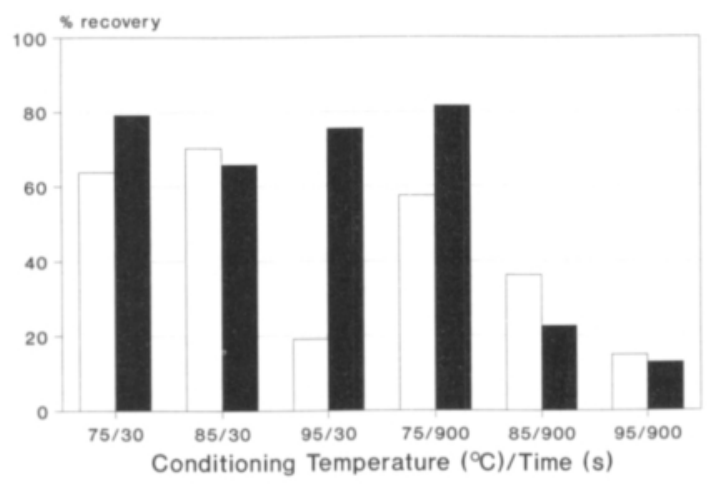

Fig. 1. $\beta$-glucanase recovery ( $\%$ of corresponding control) in feed samples after pelleting at different conditioning temperatures and times estimated either by in-feed enzyme analysis ( $\square$ ) or digesta viscosity reduction in broiler chickens (). they are still able to hydrolyse fibre polysaccharides, since they possess an arm-like movable structure which allows the active site to continue in the formation of enzyme-substrate complexes (DIN et al. 1991). The attraction between the CBD and crystalline cellulose seems to be mediated through a hydrophobic interaction. The rapidity of this interaction will, therefore, be dependent upon the presence of water and temperature. This may partly explain the apparently low enzyme activity recoveries in steam heat-treated feeds assayed by methods including an extraction step. Estimating enzyme activity in pelleted feeds using methods without an extraction step or in-vivo would, therefore, seem more appropriate. Based on the results of the digesta viscosity measurements (I) it would appear that the enzyme employed had retained most of its activity during conditioning in temperatures up to $85^{\circ} \mathrm{C}$. At the longer conditioning times enzyme recoveries were reduced.

Susceptibility to inactivation (denaturation) of enzymes in low $\mathrm{pH}$ and proteolytic conditions appeared to differ between enzyme source and method of stabilisation (II). In general, the crude enzymes seemed to possess an inherent stability to conditions resembling those in the GI tract of the pig. With the addition of wheat gluten to the incubations the magnitude of inactivation was generally reduced. When a commercial feed enzyme product was employed, which had been stabilised by spraying liquid enzymes onto a wheat-based carrier material and then dried in low temperature, neither $\beta$-glucanase nor xylanase activities were significantly reduced due to the treatments. This is probably due to the buffering capacity of the carrier material, which also provided substrates to the en- 


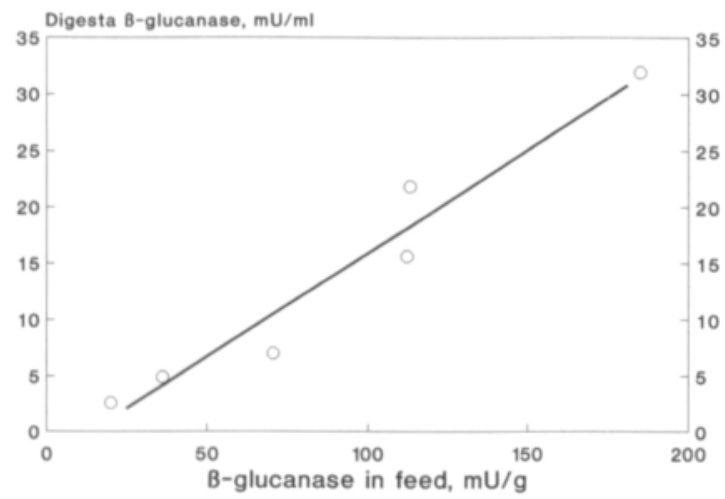

Fig. 2. Correlation between $\beta$-glucanase activity in feed and digesta samples of broiler chickens $\left(r^{2}=0.948\right)$.

zymes. DE CORDT et al. (1992) found that both polyols and carbohydrates are powerful stabilisers for both dissolved and immobilised B. licheniformis $\alpha$-amylase. When the stabilised feed enzyme product was fed to broiler chickens, $\beta$-glucanase was fully recovered in digesta samples obtained in the proximal small intestine (Figure 2, I). In samples obtained from the stomach of pigs fed enzymesupplemented diets, recovery rates decreased with time and were between 10 and $20 \%$ four hours after feeding (Figure 3, III). This was probably due to inactivation as $\mathrm{pH}$ of the gastric contents decreased and would suggest that the physiological conditions

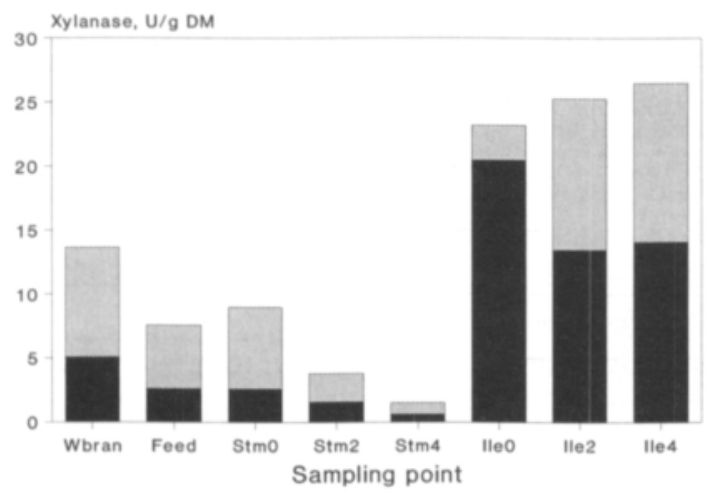

Fig. 3. Endogenous $(\mathbf{E})$ and added $(\square)$ xylanase and $\beta$-glucanase activities of feed and digesta samples of pigs fed enzyme-supplemented diets. Digesta samples were collected of the upper gastrointestinal tract may cause a certain degree of inactivation of supplementary enzymes. Interspecies differences in this respect may be due to different feed passage rates and $\mathrm{pH}$ in the gastric regions. In samples obtained at the terminal ileum of pigs the proportion of added xylanase and $\beta$-glucanase activities increased during the period between 2 and 6 hours after feeding compared to that between 0 and 2 hours after feeding (Figure 3, III). These results give evidence of partial survival of the added enzymes through the GI tract to the end of the small intestine. Consequently, provided the enzymes to be employed are selected according to the target substrates, are added in sufficient amounts and are active in the conditions of the GI tract (appropriate $\mathrm{pH}$ and temperature optima) a physiological response can be expected.

\section{Site and mode of action of carbohydrate- degrading enzymes}

Employing techniques based on sampling of ileal digesta by cannulation or total collection of faeces has usually failed to demonstrate any significant effects (GRAHAM et al. 1986, THACKER et al. 1992) or has only given a small response (GRAHAM et al. 1988a, b, INBORR and GRAHAM 1991) in nutrient digestibility of pigs, although the effects on growth and feed conversion in some experiments have

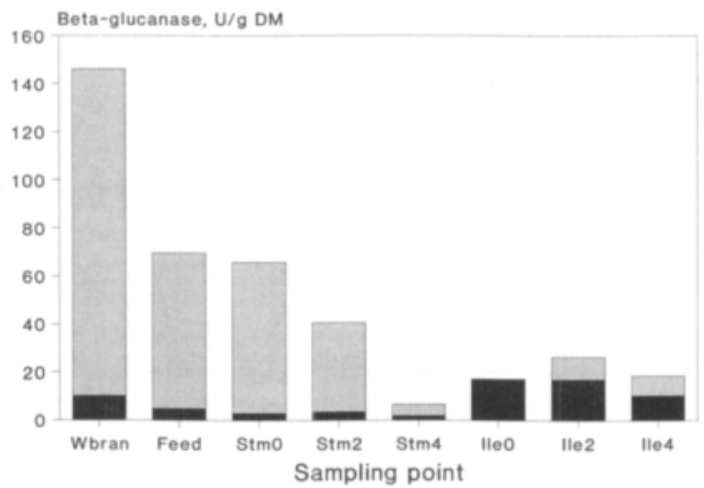

from the stomach $0(\mathrm{Stm} 0), 2(\mathrm{Stm} 2)$ and $4(\mathrm{Stm} 4)$ hours and terminal ileum between 0-2 (lle0), 2-4 (Ile2) and 4-6 (Ile4) hours after feeding. 


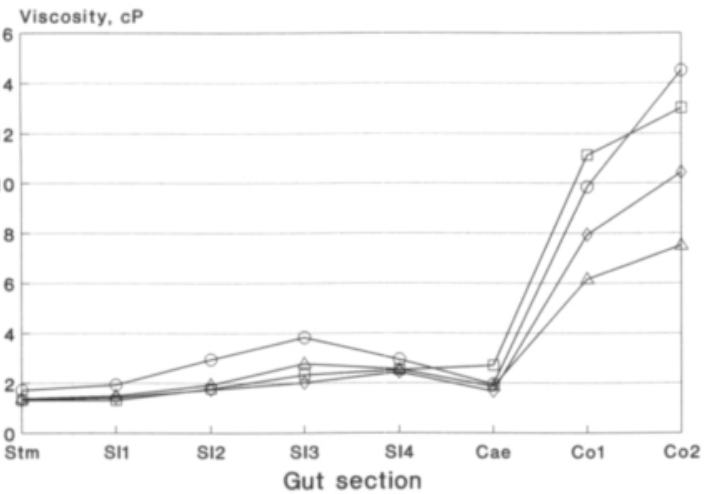

Fig. 4. Viscosity of digesta of pigs fed a hulled barley (var. Arra) with $(\Delta-\Delta)$ and without $(\diamond-\diamond)$ and a hulless barley (var. Condor) with $(\square-\square)$ and without $(\bigcirc-\bigcirc) \beta$-glucanase supplementation. A significant effect of the enzyme was observed in the stomach $(\mathrm{P}=0.029)$, first ( $\mathrm{SI} 1 ; \mathrm{P}=0.021)$, second $(\mathrm{SI} 2 ; \mathrm{P}=0.004)$ and third $(\mathrm{SI} 3 ; \mathrm{P}=0.007)$ quarter of the small intestine.

been quite dramatic following enzyme supplementation (BöHME 1990, NEWMAN et al. 1992). Consequently, it appears that these techniques are not sufficiently sensitive to describe the action of the added enzymes and that the point of digesta sampling need to be more anterior to aviod treatment effects being masked by e.g. microbial fermentation. Hence, collecting samples from the entire small intestine or even from the whole gastrointestinal tract by slaughter technique may prove a more successful way of investigating the effects of supplementary enzymes. This technique was successfully employed by INBORR et al. (1991) and, therefore, selected for experiments IV and V. The results of the two latter experiments will be used to try and explain how and where the added enzymes exert their activity in the pig. The results of these two experiments will be discussed in the following.

In both experiments, supplementation of the diets with a mixture of enzymes containing $\beta$-glucanase (IV) or a single $\beta$-glucanase preparation (V) significantly increased the digestibility of dietary $\beta$-glucans in the small intestine. In experiment $\mathrm{V}$, this was accompanied by a significant reduction in digesta viscosity in the stomach and the three anterior sections of the small intestine (Figure 4). In

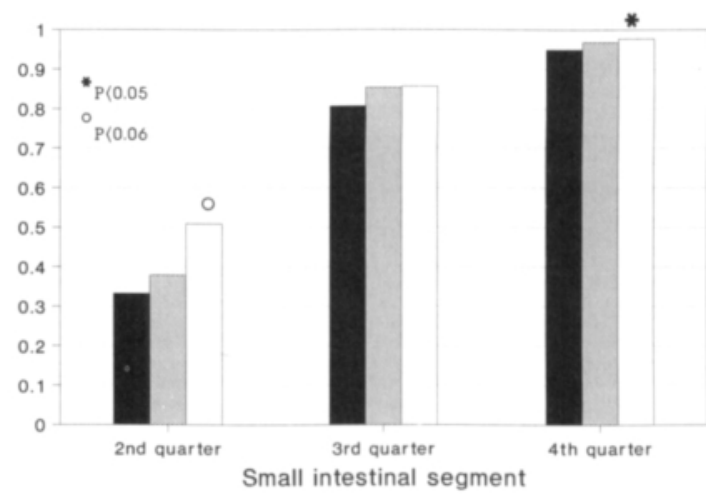

Fig. 5. Effect of supplementation of a barley/wheat-based diet without $(\mathbf{\square})$ or with enzyme $\mathrm{C}(\square)$ or enzyme $\mathrm{M}(\square)$ on starch digestibility in the three last quarters of the small intestine of early-weaned pigs. Enzyme mixtures $\mathrm{C}$ and $\mathrm{M}$ contained amylase and xylanase from the same sources but differed by containing $\beta$-glucanase from two separate $T$. longibrachiatum sources.

experiment IV, microbial amylase was included in the enzyme mixture employed, whereas in experiment $\mathrm{V}$, only a single enzyme preparation containing $\beta$-glucanase was used. This may explain why in experiment IV starch digestibility increased significantly due to enzyme supplementation (Figure 5), but was unaffected in experiment V. Interestingly, the digesta samples obtained from the three proximal quarters of the small intestine contained on average $20 \%$ less amylase activity when $\beta$-glucanase was added, without reducing starch digestibility (Table 2, V). This observation would suggest that the conditions for starch digestion were more optimal in the presence of the $\beta$-glucanase, probably due to reduced viscosity in the lumen. These observations are in contrast with those reported from studies with poultry (ALMIRALL et al. 1993). These workers found that addition of a $\beta$-glucanase to diets based on barley significantly increased amylase activity in the small intestine of broiler chickens and one-year-old cocks. It is possible that there are species differences with regard to the feed-back mechanisms regulating pancratic exocrine secretion. It has been shown that increased viscosity caused by rye non-starch polysaccharides reduce the rate of nutrient diffusion and absorption 
Table 2. Mean digestive enzyme activities ( $\mathrm{mU} / \mathrm{g}$ digesta dry matter) of the three proximal quarters of the small intestine of pigs fed either Arra or Condor barley without (-) or with (+) added $\beta$-glucanase.

\begin{tabular}{lrrrrrr}
\hline & Arra- & Arra + & Condor- & Condor + & $\begin{array}{c}\text { P-value } \\
\text { (enzyme) }\end{array}$ & $\begin{array}{r}\text { Pooled } \\
\text { variance }\end{array}$ \\
\hline Trypsin & 10.5 & 10.6 & 12.5 & 10.2 & 0.034 & 6.38 \\
Chymotrypsin & 0.10 & 0.15 & 0.15 & 0.09 & 0.059 & 0.074 \\
Lipase & 76.6 & 67.5 & 91.2 & 68.3 & 0.077 & 76.6 \\
Amylase & 997 & 787 & 816 & 626 & 0.038 & 576 \\
\hline
\end{tabular}

in-vitro (FENGLER and MARQUARDT 1988) and that reduction of intestinal viscosity improves the nutrient digestibility and subsequent performance of broiler chickens (PETTERSSON 1988, BEDFORD and Classen 1992, Almirall et al. 1993). In pigs, feeding viscous polysaccharides has been shown to increase digesta viscosity (ROBERTS et al. 1990, POTKINS et al. 1991) and pancreatic exocrine sectretion (CHERBUT et al. 1990). $\beta$-glucanase supplementation of a pig starter diet based on a hulless barley significantly improved the apparent protein digestibility over the entire small intestine and tended to reduce digesta viscosity (BEDFORD et al. 1992). These workers assumed that the enzyme increased the rate of protein digestion and absorption due to the reduced viscosity and by degrading cell wall polysaccharides interfering with the digestion. However, based on the results of experiment $\mathrm{V}$, a reduced output of digestive enzymes may have contributed to the increased apparent protein digestibility. In pigs fitted with catheters in the pancreatic duct and fed the same diets as in experiment $\mathrm{V}$, it was found that in the presence of $\beta$-glucanase the pancreatic exocrine secretion of protein was reduced (SKOU JENSEN, unpublished). If reduction of the luminal viscosity allows nutrients to be digested and absorbed at an equal rate with significantly less digestive enzyme production, this should lead to reduced endogenous losses and reduced energy requirements for enzyme synthesis and secretion and, consequently, an improvement in dietary energy utilisation. PIERZYNOWSKI (1991) estimated the daily pancreatic exocrine protein secretion in pigs up to $20 \mathrm{~kg}$ liveweight between 2 and $6 \mathrm{~g}$, whereas in pigs of varying age this secretion has been estimated to between 9 and $36 \mathrm{~g}$ (Souf-
FRANT 1991). If intestinal amylases are added to this a $20 \%$ reduction in enzyme activity may represent approximately $2 \mathrm{~g}$ protein or 5 per cent of the daily protein retention of pigs during the postweaning period. The increased liveweight gain and improved feed utilisation observed in experiment $\mathrm{V}$ would indicate that dietary energy and protein were more efficiently utilised in the presence of the $\beta$-glucanase.

Increasing the rate of digestion and nutrient absorption in the small intestine effectively means less available substrates for the intestinal microflora. In experiments with broiler chickens it has been shown that enzyme supplementation of barley-based diets reduces the microbial count in the small intestine (SALIH et al. 1991). This is thought to be a consequence of an increased feed passage rate and reduced concentration of nutrients in the lumen of the posterior intestine. In studies with early-weaned pigs, application of mixtures of fibreand starch-degrading enzymes has lead to significant reductions in the frequency and severity of diarrhoea (INBORR and OGLE 1988, BÖHME 1990), indicating reduced microbial activity in the hind gut. These results are supported by the ones obtained in the two slaughter experiments (IV, V). In experiment IV, the application of a mixture containing $\beta$-glucanase, xylanase and amylase resulted in a significantly improved starch digestibility in the last quarter of the small intestine (Figure 5). However, the most dramatic response was seen in the second quarter (Figure 5, $\mathrm{P}<0.06$ ), indicating a clear shift of the digestion from the distal to the proximal parts of the small intestine. Based on the above one can assume that increasing the rate and changing site of digestion by enzyme supplementa- 


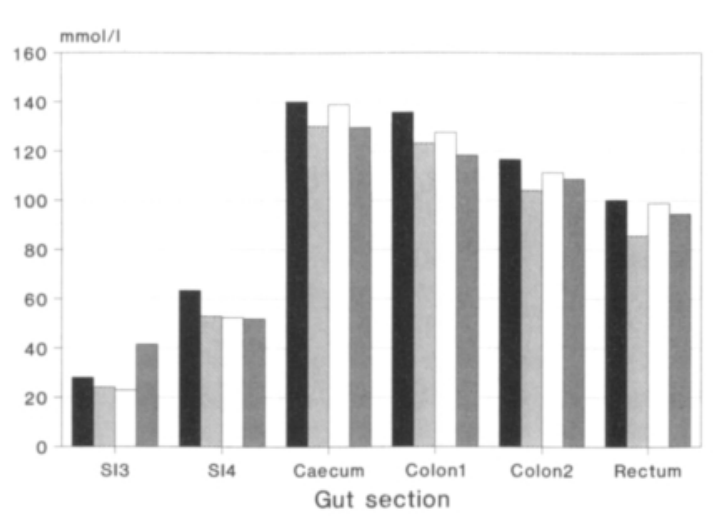

Fig. 6. Concentration of the main VFAs (acetic, propionic and butyric acids) and lactic acid in the third (SI3) and fourth (SI4) quarters of the small intestine, ceacum, ascending (Colon1) and descending (Colon2) colon and rectum of pigs fed either a hulless (var. Condor) without ( $\mathbf{\square})$ or with ( $\square$ ), or a hulled (var. Arra) barley without $(\square)$ or with $(\mathbb{Q})$ added $\beta$-glucanase. A significant effect of enzyme $(\mathrm{P}=0.044)$ was observed.

tion in this fashion leads to a reduced microbial activity in the pig caecum and colon, thus reducing the incidence of digestive disorders such as fermentative diarrhoea as described by SKADHAUGE (1985). KAMPHUES (1987) observed increased starch, lactic acid and VFA concentrations in the hindgut of pigs suffering from diarrhoea after having consumed large amounts of feed following a 24-hour period of feed deprivation. Hence increasing nutrient digestibility and the rate of absorption by enzyme addition should alleviate the effects of such nutrient-induced digestive disorders. This assumption is supported by the results from experiment $\mathrm{V}$, where enzyme supplementation of the barley-based diets significantly $(\mathrm{P}=0.044)$ decreased the concentration of VFA and lactic acid in the distal sections of the GI tract (Figure 6) and increased the dry matter content of the chyme. Since many microbes in the gut interfere with host digestive enzymes and processes (RATCLIFFE 1985), a reduction of the microbial count will improve the overall efficiency of digestion.

In broiler chickens fed diets based on wheat and rye, it has been established that gut viscosity increases exponentially in relation to the concentration of a water-soluble high-molecular weight car- bohydrate (HMC) complex (BEDFORD and CLASSEN 1992). With increasing fibre solubility or amount of soluble fibres the higher the viscosity and the amount of water being bound in the digesta. This can lead to severe deterioration of litter quality and a high incidence of vent pasting of broilers. In experiment $\mathrm{I}$, there was a high positive correlation between digesta viscosity and the incidence of vent pasting. McCRACKEN et al. (1992) reported increased dry matter content of excreta when a commercial feed enzyme was added to a broiler diet based on wheat and barley that was produced either without or with conditioning at $85^{\circ} \mathrm{C}$ for 15 minutes before pelleting. Interestingly, conditioning increased digesta viscosity of the birds, indicating solubilisation of the fibre components due to the heat-treatment. GrAHAM et al. (1989) also observed higher concentration of soluble $\beta$-glucans in the digesta of pigs fed pelleted feeds compared to mash feeds. Adding a $\beta$-glucanase increased the digestibility of NSP more in the pelleted than the mash feed. Consequently, enzymes added to cerealbased diets appear to primarily hydrolyse the soluble fibres, thus reducing digesta viscosity and the ability of soluble fibres to bind water. In experiment $\mathrm{V}$, addition of the $\beta$-glucanase significantly increased the dry matter content of the intestinal chyme along the entire GI tract. In another experiment with early-weaned pigs, enzyme supplementation of a barley/wheat-based diet resulted in increased faecal nutrient digestibility and dry matter content and reduced manure output (INBORR 1992). These are additional effects of feed enzymes, which may be of varying economical and practical significance but, nevertheless, give further evidence of their activity.

In summary, it appears that reduction of the intestinal viscosity plays an important part of the action of supplementary dietary enzymes also in pigs (Figure 7a). However, it was not possible to find any correlation between the viscosity reduction and any of the other GI or performance parameters. This is in contrast with observations made with poultry. It is possible that the magnitude of the viscosity reduction observed in the pigs was insufficient to make accurate correlation analysis and that the number of observations were too low. Re- 


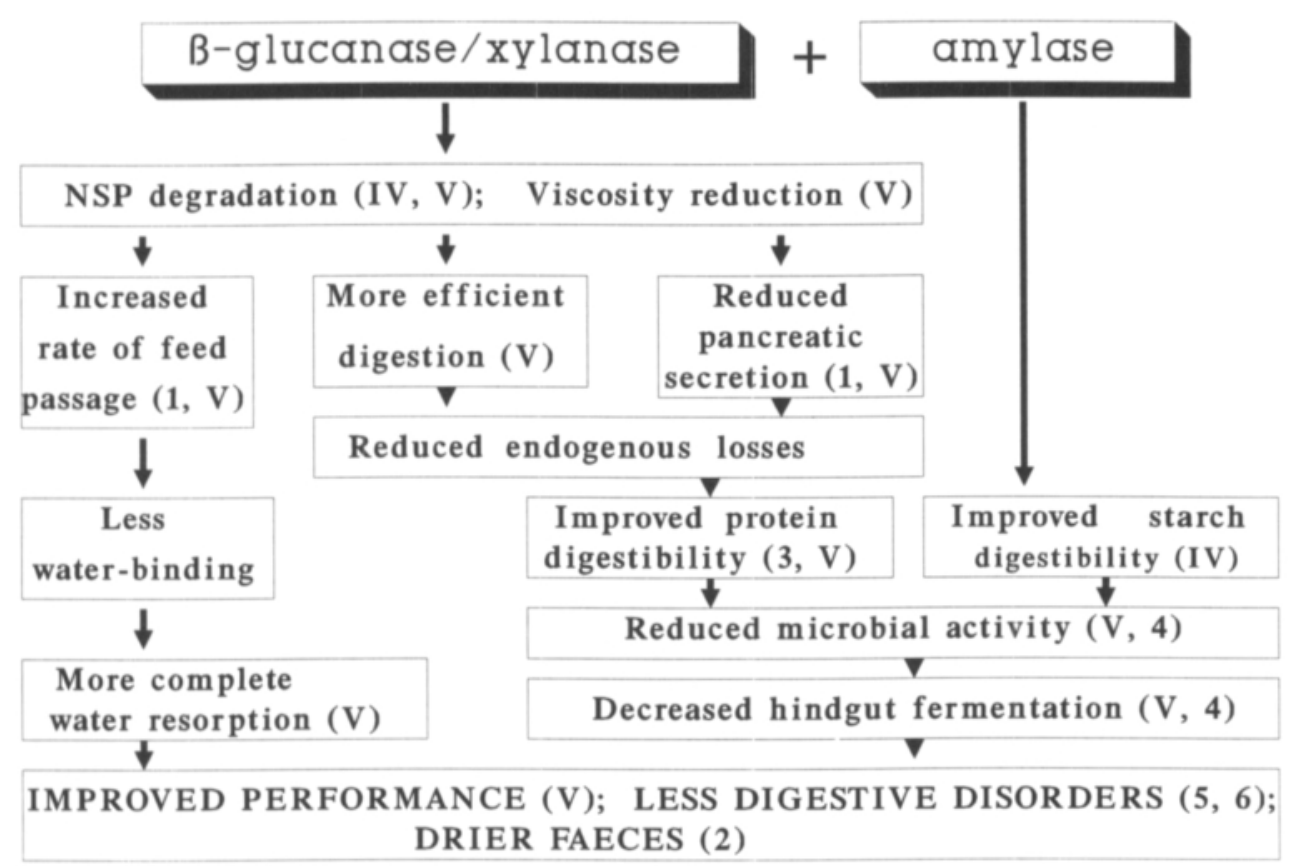

Fig. 7a. Mode of action of carbohydrate-degrading enzymes in pig starter diets based on barley and wheat (References: 1=CHERBUT et al. 1990, 2=INBORR 1992, 3=BEDFORD et al. 1992, 4=KAMPHUES 1987, 5=INBORR and OGLe 1988, 6=Вӧнме 1990).

ducing digesta viscosity by adding only fibre-degrading enzymes resulted in a decreased secretion of digestive enzymes in the pigs without affecting nutrient digestiblility. This means a more efficient digestion resulting in less endogenous losses and better utilisation of dietary energy for growth. In this situation, application of starch degrading in combination with fibre degrading enzymes appears to be of additional benefit. Not only can starch be more rapidly hydrolysed and absorbed but less easily fermentable material will reach the lower parts of the small intestine, thus reducing microbial growth and fermentation. These effects contribute into an improved animal performance, less digestive disorders and increased faeces dry matter content.

\section{CONCLUSIONS}

The stabilised feed enzyme product employed maintained its activity during the steam-pelleting process up to $85^{\circ} \mathrm{C}$ conditioning temperatures. In assessing enzyme stability and predicting the response to enzyme supplementation on animal performance the in-vivo enzyme activity assay meth- ods appeared to be superior to those carried out in-vitro.

The fungal enzymes employed appeared to possess an inherent stability to the proteolytic activities encountered in the digestive tract of pigs and poultry and it was found that wheat and wheat gluten 
can act as stabilisers to microbial enzymes probably due to their buffering capacity and by providing substrates to the enzymes.

In the stomach of pigs xylanase and $\beta$-glucanase activities were completely recovered 0.5 hours after feeding but decreased with time and were less than $20 \%$ of the initial values four hours after feeding. At the terminal ileum no added enzyme activities could be found during the first two hours after feeding, suggesting complete inactivation during the 12-hour feeding intervals. During the two subsequent two-hour periods the proportion of added in relation to endogenous enzyme activities increased, indicating that part of the added enzymes maintained their activity through to the end of the small intestine.

In pigs fed barley-based diets, $\beta$-glucanase supplementation reduced digesta viscosity and the concentration of digestive enzymes in the small intestine without affecting nutrient digestibility. These results indicate that conditions for a more efficient digestion were created, which decreased the need for digestive enzymes, thus reducing endogenous losses and increasing the amount of dietary energy and protein available for growth. This assumption was supported by the improved performance of pigs fed the enzyme supplemented barley-based diets.

Adding fibre-degrading in combination with starch-degrading enzymes to a diet based on barley and wheat significantly increased the digestibility of starch and generally inceased the rate of nutrient absorption in the proximal parts of the small intestine of early-weaned pigs. This decreases the amount of easily fermentable substrates in the hind gut and reduce microbial fermentation. $\beta$-glucanase supplementation of barley-based diets reduced the VFA and lactic acid concentration in the caecum, colon and rectum indicating reduced microbial activity in these segments.

Supplementation of pig starter diets based on barley and wheat with a combination of fibre- and starch-degrading enzymes improves liveweight gain and feed utilisation by reducing gut viscosity, rendering the digestion more efficient and reducing the microbial activity in the hindgut.

\section{REFERENCES}

Almirall, M., Brufau, J. \& EsteveGarcia, E. 1993. Effects of intestinal viscosity on digestive enzyme activities of intestinal content and ileal digestibilities of poultry fed barley diets at different ages supplemented with $\beta$-glucanases. Proceedings of the Symposium on Enzymes in Animal Nutrition, ETH Zurich. p. 69-72.

Åman, P. 1987. Analys och kemisk sammansättning av svensk spannmål. Fakta husdjur, Nr 3. Sveriges Lantbruksuniversitet. p. 4.

ARgENZIO, R. A. 1982. VFA production and absorption from the large intestine of the pig. In: Laplace, J.P. et al. (eds.). Physiologie Digestive Chez le Porc. Colloques de l'INRA, No. 12. p. 207-215.

Bach Knudsen, K.E., Borg Jensen, B., Andersen, J.O. \& HANSEN, I. 1991. Gastrointestinal implications in pigs of wheat and oat fractions. 2. Microbial activity in the gastrointestinal tract. British Journal of Nutrition 65: 233248.

Bedford, M.R. \& Classen, H.L. 1992. Reduction of intestinal viscosity through manipulation of dietary rye and pentosanase concentration is effected through changes in the carbohydrate composition of the intestinal aqueous phase and results in improved growth rate and feed conversion. Journal of Nutrition 122: 560-569.
—, Patience, J.F., Classen, H.L. \& Inborr, J. 1992. The effect of dietary enzyme supplementation of rye- and barley-based diets on digestion and subsequent performance in weanling pigs. Canadian Journal of Animal Science 72: 97-105.

Вӧнме, Н. 1990. Experiments on the effect of enzyme supplements as a growth promotor for piglets. Landbauforschung Völkenrode 40: 213-217.

BURAZCEWSKA, L . 1988. Ileal digestibility of rye fed to pigs with 'Enzyme PCl' from B. subtilis. Proceedings of the IV International Symposium on Digestive Physiology in the Pig. Polish Academy of Sciences, Institute of Animal Physiology and Nutrition. Jablonna, Poland. p. 378-380.

Cherbut, C., Albina, E., Champ, M., Doublier, J.L. \& LeCANNU, G. 1990. Action of guar gums on the viscosity of digestive contents and on the gastrointestinal motor function in pigs. Digestion 46: 205-213.

Chesson, A. 1987. Supplementary enzymes to improve the utilisation of pig and poultry diets. In: Haresign, W. \& Cole, D.J.A. (eds.). Recent advances in animal nurtition. Butterworths, London. p. 71-89.

Decordt, S., Saravia, J., Hendrickx, M., Maesmans, G. \& Tовваск, P. 1992. Changing the termostability on Bacillus licheniformis $\alpha$-amylase. Proceedings of the Interna- 
tional Symposium on 'Stability and stabilisation of enzymes'. Maastricht, The Netherlands. (Poster.)

DiERICK, N.A. 1989. Biotechnology aids to improve feed and feed digestion: enzymes and fermentation. Archives of Animal Nutrition, Berlin. 39: 241-261.

Din, N., Gilkes, N.R., Tekant, B., Miller, Jr., R.C., WarREN, R.A.J. \& KILBURN, D.G. 1991. Non-hydrolytic disruption of cellulose fibres by the binding domain of bacterial cellulase. Biotechnology 9: 1096-1099.

Englyst, H.N. \& Cummings, J.H. 1985. Measurement of starch and non-starch polysaccharides and their breakdown in the small intestine of man. In: Just, A. et al. (eds.). Digestive physiology in the pig. Copenhagen, National Institute of Animal Science. p. 188-191.

Fengler, A.S. \& MarquardT, R.R. 1988. Watersoluble pentosans from rye: II. Effects on rate of dialysis and on the retention of nutrients by the chick. Cereal Chemistry 65 : 298-302.

GoOdFrey, T. \& Reichelt, J. 1983. Industrial enzymology. 582 p. Stockton Press, New York, NY.

Goodlad, J.S. \& Mathers, J.C. 1991. Digestion by pigs of non-starch polysaccharides in wheat and raw peas (Pisum sativum) fed in mixed diets. British Journal of Nutrition 65: 259-270.

Graham, H. 1988. Dietary fibre concentration and assimilation in swine. ISI Atlas Sci. Anim. Plant Sci. 1: 76-80.

—, Åman, P. \& Löwgren, W. 1988a. Enzyme supplementation of pig diets. In: Buraczewska, L. et al. (eds.). Proceedings of the 4th International seminar on Digestive physiology in the pig. Jablonna, Polish Academy of Sciences. p. 371-376.

—, Fadel, J.G., Newman, C.W. \& Newman, R.K. 1989. Effect of pelleting and $\beta$-glucanase supplementation on the ileal and fecal digestibility of a barley-based diet in the pig. Journal of Animal Science 67: 1293-1298.

—, Hesselman, K. Jonsson, E. \& Åman, P. 1986. Influence of $\beta$-glucanase supplementation on digestion of a barleybased diet in the pig gastrointestinal tract. Nutrition Reports International 34: 1089-1096.

—, Löwgren, W., Pettersson, D. \& Åman, P. 1988b. Effect of enzyme supplementation on digestion of a barley/pollard-based pig diet. Nutrition Reports International 38: 1073-1079.

Ikegami, S., Tsuchihashi, F., Harada, H., Tsuchihashi, N., Nishide, E. \& InNAmi, S. 1990. Effect of viscous indigestible polysaccharides on pancreatic-biliary secretion and digestive organs in rats. Journal of Nutrition 120: 353360.

INBORR, J. 1992. The manure threat - a challenge for feed enzymes. Pig International, January. p. 18-19.

-, Bedford, M.R. \& Graham, H. 1993. Stability and mode of action of poultry feed enzymes in diets based on wheat and barley. Proceedings of the Australian Poultry Science Symposium, Sydney. Vol. 5: 53-56.

-, Bedford, M.R., Patience, J.F. \& Classen, H.L. 1991. The influence of supplementary feed enzymes on nutrient disappearence and digesta characteristics in the GI-tract of early-weaned pigs. Proceedings of the 5th Interna- tional Symposium on 'Digestive physiology in pigs'. Wageningen, The Netherlands. EAAP publication No. 54: 405-410.

- \& Graham, H. 1991. The effect of enzyme supplementation of a wheat/barley-based starter diet on nutrient faecal digetibility in early-weaned piglets. Animal Production 52: 565. (Abstract from the BSAP winter meeting in Scarborough, April 1991).

— \& OGle, B. 1988. Effect of enzyme treatment of piglet feeds on performance and post-weaning diarrhoea. Swedish Journal of Agricultural Research 18: 129-133.

Just, A., Fernandez, J.A. \& Jorgensen, H. 1983. The net energy value of diets for growth in pigs in relation to the fermentative processes in the digestive tract and the site of absorption of the nutrients. Livestock Production Science 10: 171-186.

KAMPHUES, J. 1987. Untersuchungen zu Verdauungsvorgängen bei Absetzferkeln in Abhängigkeit von Futtermenge und -zubereitung sowie von Futterzusătzen. Habilitationsschrift zur Erlangung der VENIA LEGENDI an der Tierärtzlichen Hochschule Hannover.

Langlois, A., Corring, T. \& Fevrier, C. 1987. Effects on wheat bran on exocrine pancreas secretion in the pig. Reproduction Nutrition Development 27: 929-939.

Low, A.G. 1985. The role of dietary fibre in digestion, absorption and metabolism. In: Just, A. et al. (eds.). Digestive physiology in the pig. Copenhagen, National Institute of Animal Science. p. 157-179.

McClean, D., McEvoy, J. \& McCracken, K.J. 1993. Effects of processing and feed enzymes on nutrient digestibility in diets for weaned pigs. Proceedings of the Nutrition Society. Vol. 52: 211A.

McCracken, K.J., Urquhart, R. \& Bedford, M.R. 1992. Effect of heat treatment and enzyme supplementation of barley-based diets on performance of broiler chickens. Proceedings of the Nutrition Society (in press).

Markström, B., Pettersson, D. \& Hesselman, K. 1985. $\beta$-glukanastillsats till grov- och finmalet korn - ett smältbarhetsförsök med smågrisar. Swedish University of Agricultural Sciences, Department of Animal Nutrition and Management. Report 149.

Meyer, J.H., Gu, Y., Elashoff, J., Reedy, T., Dressman, J. \& Amidon, G. 1986. Effects of viscosity and fluid outflow on postcibal gastric emptying of solids. American Journal of Physiology 250: G161-G164.

NÄsı, M. 1991. Digestibility and protein utilisation responses of soybean and rape seed meal to physical and enzymatic treatments in diets for growing pigs. Journal of Agricultural Science in Finland 63: 465-474.

Newman, C.W., Eslick, R.F. \& ElNegoumy, A.M. 1983. Bacterial diastase effect on the feed value of two hulless barleys for pigs. Nutrition Reports International 28: 139146.

—, Eslick, R.F., Pepper, J.W. \& ElNegoumy, A.M. 1980. Performance of pigs fed hulless and civered barleys supplemented with or without bacterial diastase. Nutrition Reports International 22: 833-836.

—, Newman, R.K. \& Danielson, A.D. 1992. Effect of supplemental enzymes on the performance of young pigs and 
broiler chicks. Proceedings of the 43rd Montana Livestock Nutrition Conference. Manuscript, p. 8.

Nieves, R.A., Eluis, R.P., Todd, R.J., Johnson, T.J.A., Grohmann, K \& Himmel. 1991. Visualization of Trichoderma reesei cellobiohydrolase I and endoglucanase I on aspen cellulose by using antibody-colloidal gold conjugates. Applied and Environmental Microbiology 57: 3163-3170.

Pettersson, D. 1988. Composition and productive value for broiler chickens of wheat, triticale and rye. $\mathrm{PhD}$ thesis. Swedish University of Agricultural Sciences, Department of Animal Nutrition and Management. Rapport 177, Uppsala.

PIERZYNOWSKI, S. 1991. Development and regulation of porcine pancreatic function with special reference to the exocrine pancreas. PhD thesis. Dept. of Animal Physiology, University of Lund, Sweden.

Poole, D.M., Durrant, A.J., Hazelwood, G.P. \& Gilbert, H.J. 1991. Characterisation of hybrid proteins consisting of the catalytic domains of Clostridium and Ruminococcus endoglucanases, fused Pseudomonas noncatalytic cellulose-binding domains. Biochemical Journal 279: 787-792.

Potkins, Z.V., LaWrence, T.L.J. \& Thomlinson, J.R. 1991. Effects of structural and nonstructural polysaccharides in the diet of the growing pig on gastric emptying rate and rate of passage of digesta to the terminal ileum and through the total gastrointestinal tract. British Journal of Nutrition 65: 391-413.

RAINBIRD, A.L. \& Low, A.G. 1986. Effect of various types of dietary fibre on gastric emptying in growing pigs. British Journal of Nutrition 55: 111-121.

RATCLIFF, B. 1985. The influence of the gut microflora on the digestive processes. In: Just, A. et al. (eds.). Digestive physiology in the pig. Copenhagen, National Institute of Animal Science. p. 245-267.

Rerat, A., Fiszlewicz, M., Giusi, A. \& Vaugelade, P. 1987. Influence of meal frequency on postprandial variations in the production and absorption of volatile fatty acids in the digestive tract of concious pigs. Journal of Animal Science 64: 448-456.

RoвerTs, F.G., Sмiтн, H.A., Low, A.G. \& Eluis, P.R. 1990.
Influence of wheat breads containing guar flour supplemenation of high and low molecular weights on viscosity of jejunal digesta in the pig. In: Southgate, D.A.T. et al. (eds.). Dietary fibre: Chemical and biological aspects. Special publication No. 83, Royal Society of Chemistry. p. 164168.

Salih, M.E., Classen, H.L. \& Campbell, G.L. 1991. Response of chickens fed hull-less barley to dietary $\beta$-glucanases at different ages. Animal Feed Science and Technology 33: 139-149.

SKadHaUGE, E. 1985. The secretory response of the digestive tract to the diet. In: Just, A. et al. (eds.). Digestive physiology in the pig. Copenhagen, National Institute of Animal Science. p. 81-100.

SoufFRANT, W.G. 1991. Endogenous nitrogen losses during digestion in pigs. In: Verstegen, M.W.A. et al. (eds.). Proceedings of the Vth International Symposium on Digestive Physiology in Pigs. EAAP publication No. 54. Pudoc, Wageningen. p. 147-167.

Tangendaja, B., Johnson, Z.B. \& Noland, P.R. 1988. Effect of cooking and addition of enzymes on feeding value of rice bran for swine. Nutrition Reports International 37: 449-459.

Thacker, P.A., Campbell, G.L. \& Grootwassink, J.W.D. 1992. Effect of salinomycin and enzyme supplementation on nutrient digestibility and the performance of pigs fed barley- or rye-based diets. Canadian Journal of Animal Science 72: 117-125.

Thomke, S., Rundgren, M. \& Hesselman, K. 1980. Effects of feeding high-viscosity barley to pigs. 31 st EAAP Congress, Munich. Session N 6:2.

Trowell, H., Southgate, D.A.T., Wolever, T.M.S., Leeds, A.R., Gassull, M.A. \& Jenkins, D.J.A. 1976. Dietary fibre redefined. Lancet 1: 97.

Yen, J.T., Nienaber, J.A., HILl, D.A. \& Pond, W.G. 1991. Potential contribution of absorbed volatile fatty acids to whole-animal energy requirement in concious swine. Journal of Animal Science 69: 2001-2012.

ZebrowsKa, T. \& Low, A.G. 1987. The influence of diets based on whole wheat, wheat flour and wheat bran on exocrine pancreatic secretion in pigs. Journal of Nutrition 117: 1212-1216. 


\title{
SELOSTUS
}

\section{Hiilihydraatteja pilkkovien entsyymien lisäys porsasrehuihin - stabiilisuus, aktiivisuus ja toimintatavat}

\author{
JOHAN INBORR
}

Helsingin yliopisto

Rehuentsyymien stabiilisuutta rakeistuksessa sekä sian ja kanan ruoansulatuskanavaa muistuttavissa olosuhteissa tutkittiin in-vitro- ja in-vivo -menetelmiä käyttäen kaikkiaan kolmessa eri kokeessa. Entsyymilisäysten aikaansaamia porsaiden tuotantotuloksiin vaikuttavia tekijöitä tutkittiin lisäksi ohra- ja vehnäpohjaisilla rehuilla kahdessa eri kokeessa.

Käytetyt rehuentsyymit säilyttivät rakeistuskokeiden tulosten mukaan aktiivisuutensa $85^{\circ} \mathrm{C}$ :een asti. Käytetyn in-vitro -menetelmän todettiin aliarvioivan rakeistetussa rehussa säilyvää entsyymiaktiivisuutta. Broilereiden ohutsuolen sisällön viskositeetin mittaamiseen perustuva in-vivo -menetelmä soveltui paremmin tähän tarkoitukseen. Ohutsuolen sisällön viskositeetin, broilereiden kasvun $\left(r^{2}=0.624\right)$ ja rehun hyväksikäytön $\left(r^{2}=0.616\right)$ välillä todettiin voimakas negatiivinen korrelaatio. Ruoansulatuskanavaa jäljittelevissä olosuhteissa tehdyt in-vitro -inkuboinnit osoittivat entsyymien inaktivoitumisen olevan văhäistä. Lisăksi vehnä ja vehnägluteeni paransivat entsyymien stabiilisuutta niiden puskoroivien vaikutusten ansiosta tai toimimalla entsyymien kiinnityskohteina. Saadut tulokset olivat yhdenmukaisia broilereilla ja sioilla saatujen tulosten kanssa. Rehuun lisätty koko ksylanaasi- ja $\beta$-glukanaasimäärä säilyi sian mahalaukussa puolen tunnin ajan ruokinnasta ja $10-20 \%$ lisätystä entsyymimäärästä todettiin vielä 4 tuntia ruokinnan jälkeen. Lisätyistä entsyymeistä säilyi suurempi osuus 2-6 tuntia ruokinnan jälkeen kuin kahden ensimmäisen tunnin aikana. Ohrapohjaiseen rehuun lisätty $\beta$-glukanaasi säilyi kokonaisuudessaan broilerin ohutsuolessa. Nämä tulokset osoittavat, että käytetyt entsyymit kestävät ruoansulatuskanavan proteolyyttisiä olosuhteita suhteellisen hyvin.

Porsaat sulattivat ohra- ja vehnäpohjaisten rehujen $\beta$-glukaania, tärkkelystä ja kuiva-ainetta paremmin $(\mathrm{P}<0.05)$, kun rehuun oli lisätty kuitua ja tärkkelystä hajottavaa entsyymiseosta. Tästä huolimatta porsaiden kasvu ja rehun hyväksikäyttö eivät parantuneet. Lisättäessä rehuun entsyymejä todettiin, että ruoansulatus nopeutui ja suurempi osuus ravintoaineista imeytyi ohutsuolen alkupuolella. Toisen kokeen tulosten mukaan $\beta$-glukanaasilisäys paransi porsaiden kasvua $(\mathrm{P}=0.074)$ ja rehun hyväksikäyttöä $(\mathrm{P}=0.058)$, kun rehussa oli joko vähän tai runsaasti $\beta$-glukaania sisältävää ohraa. Ravintoaineiden sulavuuteen ei käsittelyllä ollut vaikutusta, mutta sekä ruokasulan viskositeetti $(\mathrm{P}<0.03)$ että ruoansulatusentsyy- mien määrä $(\mathrm{P}<0.08)$ vähenivät. Viskositeetin vähentyminen sai aikaan optimaalisemmat olosuhteet ruoansulatuksen tehostumiselle. Tällöin tarvittiin vähemmän ruoansulatusentsyymejä vertailuryhmäăn năhden sulavuuden kuitenkaan heikentymättä. Tämä on ilmeisesti yhteydessä alentuneeseen endogeeniseen eritykseen ja tehostuneeseen energian hyväksikäyttöön. Tämän lisäksi entsyymilisäys văhensi $(\mathrm{P}=0.044)$ haihtuvien rasvahappojen määrää umpi- ja paksusuolessa, mikä viittaa alentuneeseen mikrobiaktiivisuuteen.

Yhteenvetona voidaan todeta, että ohra- ja vehnäpohjaisiin rehuihin lisätyt kuitua ja tärkkelystä hajoittavat entsyymit säilyttivät aktiivisuutensa ja toimivat ohutsuolessa vähentảen ruokasulan viskositeettia sekä luoden ruoansulatukselle otollisemmat olosuhteet. Ruoansulatusentsyymejä tarvitaan siten văhemmän ja ravintoaineiden imeytyminen tehostuu ohutsuolen alkuosasta. Tästä on seurauksena mikrobitoiminnan vähentyminen umpi- ja paksusuolessa, millä on vaikutusta porsaiden terveydentilaan. Nämä tekijät yhdessä edistävät porsaiden kasvua and rehun hyväksikäyttöä (Kuvio 7b).

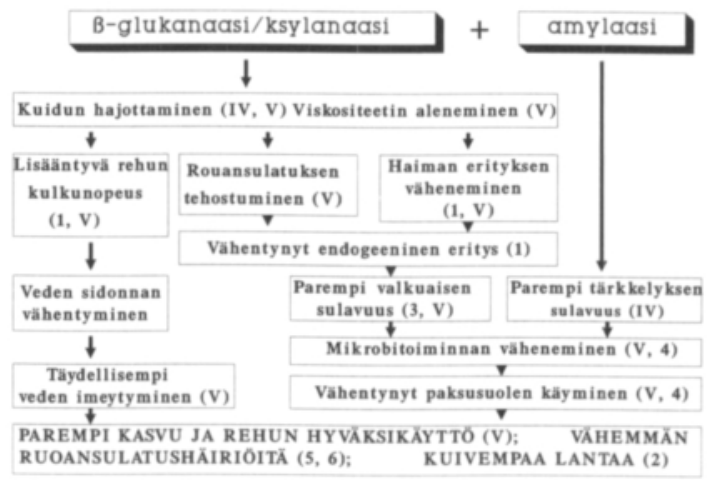

Kuva 7b. Ohra- ja vehnäpohjaisiin rehuihin lisättyjen hiilihydraatteja pilkkovien entsyymien toimintatavat porsailla (Kirjallisuusviitteet: 1=CHERBUT et al. 1990, 2=INBORR 1992, 3 =BEDFORD et al. 1992, 4=KAMPHUES 1987, 5=INBORR ja OGLE 1988, 6=Вӧнме 1990). 


\title{
Tillsats av kolhydratspjälkande enzymer till smågrisfoder - stabilitet, aktivitet och verkningssätt
}

\author{
JOHAN INBORR
}

Helsingfors universitet

Inom detta projekt genomfördes sammanlagt fem försök för att undersöka stabiliteten hos foderenzymer under pelletering och de proteolytiska förhållanden som råder i matspjälkningskanalen hos svin och höns. Dessutom gjordes ett försök att förklara de mekanismer som står bakom den höjda tillväxthastigheten och det förbättrade foderutnyttjandet hos grisar som utfodrats med korn- och vetebaserade foder med enzymtillsats.

Pelleteringsförsöket visade att den foderenzym som användes tålde en förkonditionering i temperaturer upp till $85{ }^{\circ} \mathrm{C}$ utan att förlora sin aktivitet. Vidare kunde konstateras att mäta den kvarblivna aktiviteten efter pelleteringen i foder med in-vitro analysmetoder underestimerar den verkliga aktiviteten. För detta ändamål är in-vivo modeller, som t.ex. den som baserar sig på mätning av tarminnehållets viskositet hos slaktkycklingar, bättre lämpade. Dessutom var korrelationen hög mellan tarminnehållets viskositet och slaktkycklingarnas tillväxt $\left(r^{2}=0.624\right)$ och foderutnyttjande $\left(r^{2}=0.616\right)$. Inkubationerna in-vitro, motsvarande förhållandena i matspjälkningskanalen, visade att enzymer inte inaktivieras under kortare perioder $\mathrm{i}$ en sådan miljö och att vete och vetegluten förbättrade stabiliteten antingen genom sin bufferverkan eller genom att de innehåller substrat som enzymerna kan bindas till. Dessa resultat stöds av de observationer som gjordes med slaktkycklingar och svin. Tillsatt xylanas och $\beta$-glucanas kunde helt återfinnas i prov tagna ur magsäcken hos svin en halv timme efter utfodring, medan $10-20 \%$ fortfarande kunde återfinnas 4 timmar efter utfodring. Proportionellt sett kunde mer tillsatt enzymeaktivitet återfinnas i prov tagna från slutet av tunntarmen (ileum) under perioden 2 till 6 timmar jämfört med perioden 0 till 2 timmar efter utfodringen. Hos slaktkycklingar som utfodrades med tillsatta enzymer i fodret kunde allt $\beta$-glukanas återfinnas i prov tagna från tunntarmens övre halva. Dehär resultaten ger bevis på att de enzymer som användes är relativt stabila i matspjälkningskanalen.

Genom att tillsätta en blandning av fiber- och stärkelsenedbrytande enzymer till ett foder innehållande vete och korn, förbättrades smältbarheten hos $\beta$-glukan, stärkelse och torrsubstans $(\mathrm{P}<0.05)$ i den sista fjärdedelen av tunntarmen hos smågrisar. Trots att denhär förbättringen inte ledde till en bättre tillväxt eller ett bättre foderutnyttjande, visade resultaten att matspjälkningen accelererades och en större mängd näringsämnen absorberades högre upp i tunntarmen då enzymerna tillsattes. I ett annat likadant försök tillsattes ett $\beta$ glukanas till foder baserade på antingen ett korn med låg eller hög $\beta$-glukanhalt. Detta resulterade i en högre daglig tillväxt
$(\mathrm{P}=0.074)$ och ett bättre foderutnyttjande $(\mathrm{P}=0.058)$. Fodrets smältbarhet förblev oförändrat, men tarminnehållets viskositet $(\mathrm{P}<0.03)$ och mängden pankreasenzymer $(\mathrm{P}<0.08)$ i de tre första fjärdedelarna av tunntarmen reducerades genom $\beta$. glukanastillsatsen. Det verkar som om förutsättningar för en mera effektiv matspjälkning skapades genom den sänkta tarmviskositeten. Därigenom krävdes mindre măngd matspjälkningsenzymer för att uppnå en lika hög smältbarhet som hos kontrollgruppen. Detta torde leda till mindre endogena förluster och ett förbättrat utnyttjande av energin för tillväxt. Dessutom uppmättes en lägre $(\mathrm{P}=0.044)$ koncentration av flyktiga fettsyror i blind- och tjocktarmen hos grisarna, vilket tyder på en minskad mikrobiell fermentation.

Sammanfattningsvist kan konstateras att rätt valda fiberoch stärkelsenedbrytande enzymer, som tillsatts till foder baserade på korn och vete, bibehåller sin aktivitet och verkar i tunntarmen genom att minska tarminnehållets viskositet och skapa förutsättningar för en effektivare matspjälkning (Figur $7 \mathrm{c})$. Mindre mängd matspjälkningsenzymer behövs och en större mängd näringsämnen absorberas i de främre delarna av tunntarmen. Detta leder vidare till en minskad mikrobiell aktivitet i blind- och tjocktarmen, vilket främjar grisarnas hälsotillstånd. Alla dessa faktorer bidrar till en förbättrad tillväxt och ett mera effektivt foderutnyttjande.

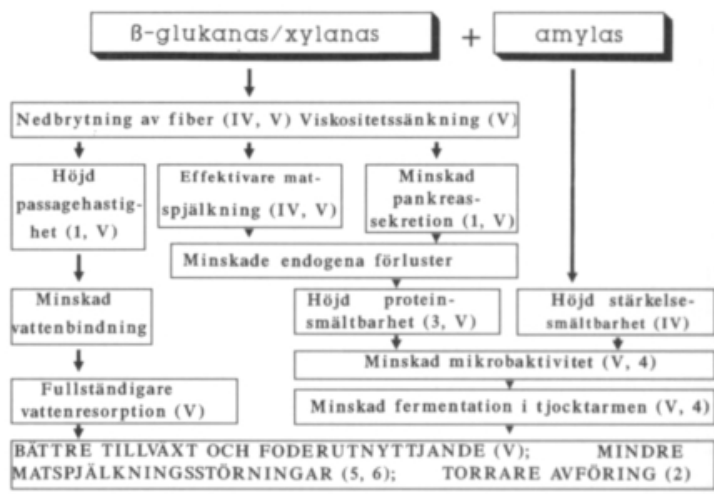

Fig. 7c. Verkningssätt hos kolhydratspjälkande enzymer i smågrisfoder baserat på korn och vete (Litteraturhänvisningar: 1=CHERBUT et al. 1990, 2=INBORR 1992, 3=BEDFORD et al. 1992, 4=KAMPHUES 1987, 5=INBORR och OGLE 1988, 6=Вӧнме 1990). 


\title{
Zusatz von kohlenhydratspaltenden Enzymen zu Ferkelfutter - Stabilität, Aktivität und Wirkungsweise
}

\author{
JOHAN INBORR
}

Universität Helsinki

In insgesamt fünf Versuchen wurde die Stabilität von Futterenzymen unter Bedingungen der Dampfpelletierung und der proteolytischen Gegebenheiten im Verdauungstrakt bei Schweinen und Geflügel untersucht. In einzelnen wurde zu klären versucht, welche Mechanismen die Leistungssteigerung bei Schweinen bewirken, wenn Futterenzyme Getreiderationen zugemischt werden.

Die Versuchsergebnisse zur Pelletierstabilität zeigen, daß die Enzymaktivitäten des untersuchten Enzympräparates bis zu Temperaturen von $85{ }^{\circ} \mathrm{C}$ (bei der Konditionierung) unbeeinflußt bleiben. Untersuchungen zur Ermittlung der Wiederfindungsrate haben ergeben, daß in-vitro-Metoden die tatsảchliche Enzymaktivität im pelletierten Futter deutlich unterschätzen. In-vivo-Metoden, die auf Messungen der Viskosität des Darminhaltes der Mastküken beruhen, spiegeln die Verhältnisse exakter wieder, was sich auch in der hohen Korrelation zum Lebendmassezuwachs $\left(r^{2}=0.624\right)$ und zur Futterverwertung $\left(r^{2}=0.616\right)$ zeigte. Die in vitro-Untersuchungen, bei denen im Verdauungstrakt vergleichbar Inkubationsverhältnisse simuliert werden, ergaben, daß die Enzyme nur unvollständig abgeaut und inaktiviert werden. Weizen und Weizenglutein begünstigten die Aufrechterhaltung der Aktivitäten durch ihre Pufferkapazität bzw. durch ihre Eigenschaft als Substratdonator. Diese Befunde konnten durch in-vivo Untersuchungen gestützt werden. So werden bei Schweinen 4 Stunden nach der Fütterung 10\%-20\% der Aktivitäten im Magen wiedergefunden; 4-6 Stunden nach dem Füttern sogar deutlich höhere Anteile am Ileum. Auch bei Mastküken, denen bei einer Gerstenration Enzymzusätze verfüttert worden waren, wurde die $\beta$-Glucanase im proximalen Teil des Dünndarms vollständig wiedergefunden, was für eine ausreichende Stabilität dieses Enzyms im Verdauungstrakt spricht.

Bei Zusätzen von gerüstsubstanz- und stärkespaltenden Enzymen zu Weizen/Gerste-Rationen wurde bei früh entwöhnten Ferkeln eine verbesserte Verdaulichkeit der $\beta$-Glukane, der Futtertrockenmasse und der Stärke $(\mathrm{P}<0.05)$ im letzten Viertel des Dünndarms festgestellt. Auswirkungen auf die Wachstumsleistung und auf die Futterverwertung wurden jedoch nicht beobachtet. Es zeigte sich jedoch, daß ein größerer Anteil der Nährstoffe im vorderen Dünndarm absorbiert wurde.

In Rationen, deren Gerste einen hohen bzw. niedrigen $\beta$ Glucangehalt aufwies, führte der Zusatz von $\beta$-Glucanase bei 3wöchiger Versuchsdauer - ebenfalls zu einem besseren Lebendmassezuwachs $(\mathrm{P}=0.074)$ und zu einer besseren Futter- ausnutzung $(\mathrm{P}=0.058)$. Bei den Ferkeln war die Verdaulichkeit der Năhrstoffe nicht gesteigert; die Viskosität des Darminhaltes war jedoch herabgesetzt $(\mathrm{P}<0.03)$ und die Konzentration der Verdauungsenzyme $(\mathrm{P}<0.08)$ in den drei proximalen Vierteln des Dünndarms verringert. Offensichtlich bewirken Enzymzusătze durch Verringerung der Viskosität und durch verminderte Produktion von Pankreasenzymen effektivere Verdauungsprozesse, die sich in geringeren endogenen Verlusten und einer besseren Ausnutzung der für das Wachstum zur Verfügung stehenden Energie äußert. Im distalen Dünndarmabschnitt sowie im Dickdarm wurde zudem eine niedrigere Mikrobentätigkeit (durch die Konzentration der fl. Fettsäuren gemessen) festgestellt $(\mathrm{P}=0.044)$.

Gerüstsubstanz- und stärkespaltende Enzyme - vorausgesetzt, daß sie entsprechend selektiert sind - wirken beim Ferkel im gesamten Verdauungstrakt dadurch, daß die Viskosität des Darminhaltes herabsetzen und den Verdauungsproze $B$ effektiver gestalten (Abbildung 7d): Die Bauchspeicheldrüse hat entsprechend weniger Enzyme zu produzieren und größere Nährstoffmengen werden im vorderen Teil des Dünndarms absorbiert. Eine geringere Mikrobenaktivität in den hinteren Abschnitten des Verdauungstraktes ist die Folge und die Fermentationsverluste liegen niedriger. Insgesamt bewirken diese Effekte bei Schweinen eine Leistungssteigerung.

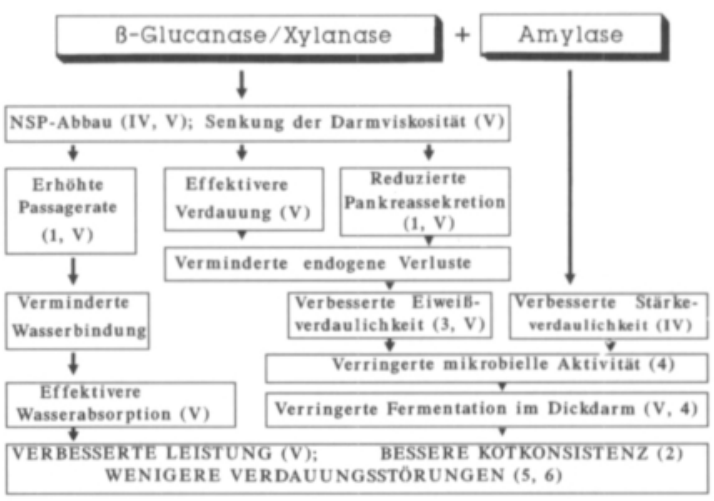

Abbildung 7d. Wirkungsweise von Enzymzusätzen bei Verfütterung von Gerste/Weizen-Rationen an Ferkel (Literaturhinweise: 1=CHERBUT et al. 1990, 2=INBORR 1992, 3=BEDFORD et al. 1992, 4=KAMPHUES 1987, 5=INBORR und OGLE 1988, 6=Вӧнме 1990). 


\title{
Stability of feed enzymes to steam pelleting during feed processing
}

\author{
J. Inborr, ${ }^{*}$, M.R. Bedford \\ Finnfeeds International Ltd., Market House, High Street, Marlborough SN8 IAA, UK
}

(Received 3 February 1993; accepted 12 October 1993)

\begin{abstract}
A barley-based diet for broiler chickens was supplemented with a commercial feed enzyme product (Avizyme SX ${ }^{\star}$, containing Trichoderma longibrachiatum $\beta$-glucanase) at 0,1 and $10 \mathrm{~g} \mathrm{~kg}^{-1}$ and pelleted after conditioning at 75,85 or $95^{\circ} \mathrm{C}$ for either $30 \mathrm{~s}$ or 15 $\min$ in a $3 \times 3 \times 2$ factorial design. The pelleted feeds were analysed for $\beta$-glucanase activity, starch, total and soluble $\beta$-glucan and non-starch polysaccharides (NSP) and fed to 1day-old male broiler chickens for a 19 day period, at the end of which, weight gain, feed intake and the incidence of vent pasting were recorded. On Day 19, four birds per treatment were killed and digesta viscosity and $\beta$-glucanase activity in the proximal part of the small intestine evaluated.

Conditioning at $75^{\circ} \mathrm{C}$ for $30 \mathrm{~s}$ reduced $\beta$-glucanase activity compared with control mash diets to $66 \%$ of initial activity, whereas $15 \mathrm{~min}$ conditioning at $75^{\circ} \mathrm{C}$ reduced recovery to $49 \%$. At $85^{\circ} \mathrm{C}$ with $30 \mathrm{~s}$ and $15 \mathrm{~min}$ conditioning, the recoveries were $56 \%$ and $31 \%$, and at $95^{\circ} \mathrm{C}$, these were $16 \%$ and $11 \%$, respectively. There was a negative quadratic effect of conditioning temperature and a positive linear effect of enzyme level on liveweight gain and feed efficiency. Conditioning time did not influence chick performance and there were no treatment effects on feed intake. The incidence of vent pasting decreased linearly with increasing enzyme inclusion rates and was significantly higher after conditioning for 15 min compared with $30 \mathrm{~s}$.

Dietary $\beta$-glucanase correlated linearly with digesta $\beta$-glucanase activity and the slope of the relationship indicated full recovery of the enzyme in the small intestine of the birds. Digesta $\beta$-glucanase activity correlated linearly with viscosity, which in turn correlated highly with bird performance. Despite this, dietary $\beta$-glucanase values required transformation to their logarithms before they could be used to accurately predict bird performance.

The results from this experiment suggest that partial enzyme inactivation occurs at pelleting. The magnitude of the inactivation depends on the pelleting conditions employed, with higher temperatures and prolonged conditioning times increasing inactivation. How-
\end{abstract}

*Corresponding author.

'Present address: Finnsugar GmbH, Raboisen 58, D-20095, Hamburg, Germany. ff

0377-8401/94/\$07.00 C 1994 Elsevier Science B.V. All rights reserved SSDI 0377-8401/

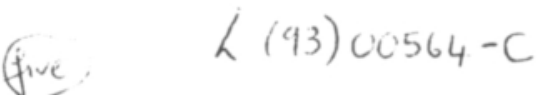


ever, in this experiment, bird performance was only affected when feeds were pelleted at temperatures over $85^{\circ} \mathrm{C}$. The viscosimetric method used for measuring $\beta$-glucanase activity in the feeds proved to give a good estimate of the in vivo activity based on digesta viscosity. However, values obtained with this method needed a logarithmic transformation for accurate prediction of chick performance, thereby reducing sensitivity with values normally encountered in feed. Digesta viscosity was a good indicator of bird performance.

\section{Introduction}

There is a considerable amount of published work showing the response in animal performance to enzyme supplementation of feeds (reviewed by Chesson (1987) and Dierick (1989)). With increased commercial use of feed enzymes in processed feeds the question of enzyme stability becomes more and more of an issue. In particular, the ability of enzymes to withstand the various heat treatments (pelleting, expansion, extrusion, etc.) now being employed in feed manufacturing is seriously questioned. Furthermore, once the enzymes enter into the gastrointestinal tract, where the enzyme action occurs, they are subjected to a range of conditions that can cause denaturation, thus rendering them inactive.

Cellulases and hemicellulases are the most commonly used enzymes in feed applications. They are mainly microbial enzymes produced by fungi and bacteria. In general, the inherent heat stability of mesophilic microbial enzymes is poor, although enzymes of different origin can differ considerably in this respect (Godfrey and Reichelt, 1983). A number of stabilisation methods have been developed to minimise these problems.

Results from chick performance experiments show significant responses to enzyme supplementation of the same feed fed either as a mash or as pellets (Inborr and Graham, 1991), indicating sufficient enzyme activity after pelleting. Consequently, enzyme stability to heat processing may not be estimable by current in vitro methods, and so alternative methods need to be developed. Bedford and Classen (1992) found a high correlation between reduced digesta viscosity and improved performance of broiler chickens fed wheat- and rye-based diets. Similar relationships were also found in barley-fed broiler chickens (Inborr et al., 1993 ). Monitoring intestinal viscosity would therefore appear suitable for estimating the relative enzyme activity in feed after pelleting.

The objectives of this study, therefore, were to investigate the effect of conditioning temperature and time during pelleting on the recovery of $\beta$-glucanase from the feed by traditional methods. These results were then to be compared with the response of broilers fed such feeds. The parameters chosen were feed conversion ratio, weight gain and intestinal viscosity.

\section{Materials and methods}

\subsection{Diets and pelleting}

Three target conditioning temperatures $\left(75,85\right.$ and $\left.95^{\circ} \mathrm{C}\right)$ and two conditioning times ( $30 \mathrm{~s}$ and $15 \mathrm{~min}$ ) were employed to investigate the influence of steam 
pelleting on enzyme activity recovery in feeds. A commercial feed enzyme product (Avizyme SX ${ }^{\otimes}$, Finnfeeds International, Marlborough, UK) was used as the $\beta$-glucanase source and added at three levels of inclusion $\left(0,1\right.$ and $\left.10 \mathrm{~g} \mathrm{~kg}^{-1}\right)$ to the basal diet to give a $3 \times 3 \times 2$ factorial design.

A basal feed mix of approximately $1800 \mathrm{~kg}$, based on barley (hulless, var. Condor) and soya-bean meal, was prepared by blending all the ingredients (Table 1), except soya oil, in a Nauta mixer before grinding in a hammer mill (sieve 2.0 $\mathrm{mm}$ ). After grinding, soya oil was added during blending. Three batches of approximately $600 \mathrm{~kg}$ each were drawn from the basal feed mix to be used for the

Table 1

Composition and nutrient content of the basal diet $\left(\mathrm{g} \mathrm{kg}^{-1}\right.$ as fed)

$\begin{array}{lc}\text { Ingredients } & \\ \text { Barley } & 602.3 \\ \text { Wheat } & 100 \\ \text { Soya-bean meal } & 200 \\ \text { Fish meal } & 20 \\ \text { Soya oil } & 35 \\ \text { Monocalcium phosphate } & 12 \\ \text { Limestone } & 13 \\ \text { L-Lysine-HCl } & 1.8 \\ \text { DL-Methionine } & 3.4 \\ \text { Vitamin/mineral premix }{ }^{-} & 10 \\ \text { Salt } & 2.5 \\ & \\ \text { Analysed nutrients } & \\ \text { Crude protein } & 203 \\ \text { Crude fat } & 65 \\ \text { Ash } & 56 \\ \text { Starch } & 393 \\ \text { Calcium } & 8.7 \\ \text { Phosphorus } & 7.3 \\ \text { Mixed-linked } \beta \text {-glucans } & \\ \quad \text { Total } & 29 \\ \text { Insoluble } & 15 \\ \text { Soluble } & 14 \\ \text { Non-starch polysaccharides } & \\ \text { Total } & 95 \\ \text { Insoluble } & 66 \\ \text { Soluble } & 29\end{array}$

Calculated nutrients

Lysine

Methionine + cystine

Metabolisable energy ( $\mathrm{MJ} \mathrm{kg}^{-1}$ )

'The premix supplied per kg diet: vitamin A, $9000 \mathrm{IU}$; vitamin $\mathrm{D}_{3}, 2000 \mathrm{IU}$; vitamin E, $12 \mathrm{IU}$; vitamin $B_{1}, 0.5 \mathrm{mg}$; vitamin $B_{2}, 4 \mathrm{mg}$; vitamin $B_{6}, 1 \mathrm{mg}$; vitamin $B_{12}, 20 \mu$; vitamin $K_{3}, 2 \mathrm{mg}$; folic acid, $0.3 \mathrm{mg}$; niacin, $15 \mathrm{mg}$; pantothenic acid, $12.5 \mathrm{mg}$; choline, $173.5 \mathrm{~g}$; Ca, $1.4 \mathrm{~g} ; \mathrm{Na}, 0.1 \mathrm{mg} ; \mathrm{Fe}, 20 \mathrm{mg}$; $\mathrm{Mg}, 0.37 \mathrm{~g} ; \mathrm{Mn}, 70$ mg; Zn, 50 mg; Cu, 7 mg; I, 0.8 mg; Se, 0.2 mg; K, 0.24 mg; Co, 0.25 mg; Endox anti-oxidant, $100 \mathrm{mg}$. 
different enzyme treatments. The enzyme was added at $0 \mathrm{~g} \mathrm{~kg}^{-1}, 1 \mathrm{~g} \mathrm{~kg}^{-1}$ and 10 $\mathrm{g} \mathrm{kg}^{-1}$ to one of the three batches to form Treatments NE, AO and AT, respectively. To ensure homogeneous mixing of the enzyme supplement, the required amount was first mixed with $25 \mathrm{~kg}$ of the basal feed before being blended into the rest of the batch.

The feeds were pelleted in batches of approximately $200 \mathrm{~kg}$. When the target conditioning temperature of each batch was reached, half of the batch $(100 \mathrm{~kg})$ was collected from the conditioner into insulated and numbered plastic buckets and stored for $15 \mathrm{~min}$ before being fed into the pelleter by emptying the buckets in the same sequence as they had been filled. The rest of the feed was pelleted directly after the $30 \mathrm{~s}$ of conditioning. After pelleting, the feed was spread out on a plastic sheet for cooling and drying.

Conditioning temperatures were monitored at four points of the conditioner with fixed thermometers and the temperature of the pellets exiting the die with an Infra Red thermometer (Infratherm IT 6, IMPAC Electronic GmbH, Germany). Samples were taken for enzyme activity analysis of the mash feed after mixing, and of all feeds after the cooling and drying stage following pelleting.

The pelleting machine used had a capacity of $500 \mathrm{~kg} \mathrm{~h}^{-1}$ (Model V3-30, Robinson Milling (Simon Heesen), Boxtel, Netherlands) with a power output of $18.5 \mathrm{~kW}$. The pellet diameter was $3.5 \mathrm{~mm}$, die thickness was $65 \mathrm{~mm}$ and die diameter $300 \mathrm{~mm}$. The amperage used during the pelleting varied between 16 and $17 \mathrm{~A}$.

\subsection{Chemical analysis of the diets}

The dry matter content of the feeds was determined by oven drying $\left(103^{\circ} \mathrm{C}\right.$ overnight ). Nitrogen was determined by the Kjeldahl procedure (Association of Official Analytical Chemists (AOAC), 1990), crude fat by chloroform/methanol extraction (Atkinson et al., 1972), crude fibre by the method of AOAC (1990) with Fibertec (Tecator) and starch enzymatically by the method of Åman and Hesselman (1984). The ash content of the feeds was determined after the samples were ashed in an oven at $500^{\circ} \mathrm{C}$ for $4 \mathrm{~h}$.

Total and soluble non-starch polysaccharide (NSP) content was determined according to the method of AOAC (1990). Insoluble NSP was calculated as the difference between total and soluble NSP contents.

Total and insoluble $\beta$-glucan was determined by the method of Åman and Graham (1987) and soluble $\beta$-glucan was calculated as the difference between these two fractions.

Calcium and phosphorus were determined according to the methods described by the Ministry of Agriculture, Fisheries and Food (1985).

\subsection{In vitro assays}

Enzyme activity measurements in feed and digesta

A $10 \mathrm{~g}$ feed sample was accurately weighed into a $100 \mathrm{ml}$ volumetric flask. Distilled water at room temperature was added to bring the volume up to $100 \mathrm{ml}$ 
and the suspension stirred for $30 \mathrm{~min}$ and then filtered through a glass fibre filter (Macherey Nagel 85/90, Düren, Germany). The extract was diluted to the appropriate concentration with buffer solutions according to the procedures of the methods employed.

For the collection of digesta, birds were killed by cervical dislocation and the abdominal cavity exposed. The small intestine was ligated at the duodenum and at Meckel's diverticulum. The total content of this proximal part of the small intestine was collected into a $100 \mathrm{ml}$ beaker and thoroughly mixed. Approximately $1.5 \mathrm{~g}$ (wet weight) of the fresh digesta were immediately placed in a microcentrifuge tube and centrifuged at $12700 \times \mathrm{g}$ for $2 \mathrm{~min}$. The supernatants were instantly frozen in liquid nitrogen. Before enzyme analysis the samples were thawed and filtered (Macherey Nagel 85/90).

Measurements of $\beta$-glucanase (EC 3.2.1.6; endo- $(1,3)(1,4)$-glucanase) activity in feed were carried out viscosimetrically using $1.0 \%$ barley $\beta$-glucan (Biocon Biochemicals, Cork, Ireland) in McIlvaine's buffer as substrate by the method described by Bathgate (1979) with minor modifications. This method measures the reduction in substrate viscosity and enzyme activity is expressed as the increase in reciprocal viscosity (IRV).

One percent (w/w) $\beta$-glucan substrate was prepared by solubilising $1 \mathrm{~g}$ of barley $\beta$-glucan in $6 \mathrm{ml}$ of ethanol in a tared beaker. To this was added $10 \mathrm{mi}$ of 0.5 $\mathrm{M}$ sodium acetate buffer ( $\mathrm{pH} 4.0$ ), then distilled water to a final volume of 100 $\mathrm{ml}$. The $\beta$-glucan solution was standardised to initial reciprocal specific viscosity of 0.13 by adjusting the $\beta$-glucan:buffer ratio. In the measurements the volume of the $\beta$-glucan substrate varied between 5.3 and $5.5 \mathrm{ml}$ and that of the enzyme solution between 2.0 and $2.2 \mathrm{ml}$. The total volume of the substrate/enzyme solution was adjusted to $7.5 \mathrm{ml}$ before each measurement.

After enzyme addition, four to six flow times were determined over a $30 \mathrm{~min}$ period in an Ostwald capillary viscometer (Model No. II, 75-100 s, Rudolf Brand $\mathrm{GmbH}$, Wertheim, Germany), immersed in a water bath set at $30^{\circ} \mathrm{C}$. The flow times were used to calculate the reciprocal specific viscosities, using the equation

$$
1 / \eta_{\mathrm{sp}}=\frac{\mathrm{d} T_{0}}{\mathrm{~d} T_{\mathrm{S}}-\mathrm{d} T_{0}}
$$

where $1 / \eta_{\mathrm{sp}}$ is the reciprocal specific viscosity, $\mathrm{d} T_{0}$ is the flow time of the buffer and $\mathrm{d} T_{\mathrm{S}}$ is the flow time of the substrate-enzyme solution.

$\beta$-glucanase activity is expressed as the increase in reciprocal specific viscosity (IRV) and calculated using the equation

$$
\beta \text {-glucanase, IRV units } \mathrm{g}^{-1}=\frac{k D}{V}
$$

where $k$ is the slope of the curve plotted from the reciprocal specific viscosity versus hydrolysis time $(\min ), D$ is the total dilution factor and $V$ is sample volume. One IRV unit (IRVU) is defined as the change of one $\left(1 / \eta_{\mathrm{sp}}\right)$ per min. Each measurement was carried out in duplicate.

$\beta$-glucanase activity in the digesta supernatants of birds fed the control (NE) 
and Avizyme SX, $10 \mathrm{~g} \mathrm{~kg}^{-1}$ (AT) diets were measured by the method suggested by the MegaZyme (North Rocks, N.S.W., Australia) malt $\beta$-glucanase assay kit with assay conditions modified to $30 \mathrm{~min}$ incubation time at $40^{\circ} \mathrm{C}$ in $50 \mathrm{mM}$ acetate buffer ( $\mathrm{pH} 4.6$ ). This assay gives a relative measure of enzyme activity. To obtain quantitative data, a standard assay based on release of reducing sugars using a non-dyed substrate was run parallel to the dye release method. By using Avizyme SX for calibration of the assays, the unknown activity of the digesta supernatants could be calculated. One $\beta$-glucanase unit is defined as the amount of enzyme needed to release $1 \mu \mathrm{mol}$ glucose $\mathrm{min}^{-1}$ in the described conditions.

\subsection{In vivo assays}

\subsubsection{Broiler performance trial}

This experiment was carried out in two subsequent blocks of 18 treatments each. In the first block, 270 1-day-old male broiler chickens (hybrid Ross I) were allocated to cages in groups of five birds and randomly assigned to one of the 18 treatments. In the second block the number of birds per cage was four. In all other aspects, the design was similar to that of the first block.

Birds were fed ad libitum for 19 days and water was freely available at all times through nipple drinkers. Each diet was fed as a crumble for the first week of the experiment.

The birds were bulk weighed by cage on Days 1 and 19 and feed inputs and residuals on Days 7, 14 and 19. Vent pasting was recorded in conjunction with the weighing on Day 19. All birds were scored for vent pasting and any bird with excreta adhering to the plumage around the cloaca was recorded.

Dead and culled birds were weighed at the time of removal and abnormal mortalities investigated by post mortem examination.

\subsubsection{Digesta viscosity}

On Day 19, twod birds per treatment were randomly selected for digesta viscosity measurements. Supernatant $(500 \mu \mathrm{l})$ obtained as described above was carefully withdrawn in a $200-1000 \mu$ l pipette and viscosity determined using a Brookfield digital viscometer (Model LVTDVCP-II, Brookfield Engineering Laboratories, Stoughton, MA) maintained at $20^{\circ} \mathrm{C}$ and a shear rate of $6-30 \mathrm{~s}^{-1}$.

Digesta viscosity measurements were carried out in both blocks. In addition, during the second block, digesta viscosities of three birds fed a mash control diet (NE-M) and three birds fed a pelleted $\left(75^{\circ} \mathrm{C}\right)$ control diet (NE-P) from Days 17 to 19 were measured by the procedures described above to investigate the effect of pelleting on digesta viscosity.

\subsection{Calculations and statistical analysis}

The experiment was designed as a $3 \times 2 \times 2$ factorial randomised complete block design, with blocks representing time. The data were analysed by ANOVA according to the general linear models procedure (Statistical Analysis Systems In- 
stitute, 1982). Means were separated where appropriate by contrasts. Main effects are reported only when interactions were found to be non-significant $(P>0.05)$. Where interactions were significant, analysis of variance was performed by each interactive parameter to determine the simple effects. Owing to unequal replication, least square means were used where appropriate (gut viscosity).

\section{Results}

\subsection{Chemical composition of the diets}

Starch and protein were the main components of the basal mash diet (Table 1). Conditioning temperature and time did not influence the composition of the diet (Table 2), whereas enzyme supplementation reduced the starch content $(P<0.001)$. Solubility of the mixed-linked $\beta$-glucans was on average $82 \%$ in the pelleted feeds compared with $48 \%$ in the mash.

\subsection{Enzyme activity recovery}

Actual conditioning temperatures were equal to or slightly lower than the targets for the two lower temperatures, whereas $95^{\circ} \mathrm{C}$ was not achieved during any of the batch runs (Table 3 ).

Endogenous $\beta$-glucanase activity in the unsupplemented mash feed (NE-M)

Table 2

Effect of enzyme level, pelleting time and temperature on starch, total and soluble non-starch polysaccharides (NSP) and $\beta$-glucan content of the feeds $\left(\mathrm{g} \mathrm{kg}^{-1}\right.$ as fed)

\begin{tabular}{|c|c|c|c|c|c|}
\hline Treatment & Starch & Total NSP & $\begin{array}{l}\text { Soluble } \\
\text { NSP }\end{array}$ & $\begin{array}{l}\text { Total } \beta \text { - } \\
\text { glucan }\end{array}$ & $\begin{array}{l}\text { Soluble } \\
\beta \text {-glucan }\end{array}$ \\
\hline \multicolumn{6}{|c|}{ Enzyme $\left(g \mathrm{~kg}^{-1}\right)$} \\
\hline 0 & 423 & 113 & 36 & 40 & 32 \\
\hline 1 & 373 & 107 & 35 & 40 & 34 \\
\hline 10 & 406 & 112 & 35 & 39 & 33 \\
\hline$P$-value & 0.0008 & 0.3825 & 0.9836 & 0.9319 & 0.4560 \\
\hline \multicolumn{6}{|c|}{ Temperature $\left({ }^{\circ} \mathrm{C}\right)$} \\
\hline 75 & 409 & 112 & 37 & 39 & 33 \\
\hline 85 & 395 & 113 & 36 & 40 & 33 \\
\hline 95 & 400 & 106 & 34 & 40 & 33 \\
\hline$P$-value & 0.1104 & 0.2569 & 0.8013 & 0.5802 & 0.9221 \\
\hline \multicolumn{6}{|l|}{ Time (min) } \\
\hline 0.5 & 402 & 112 & 37 & 40 & 33 \\
\hline 15 & 400 & 109 & 34 & 39 & 33 \\
\hline$P$-value & 0.3072 & 0.4728 & 0.4112 & 0.5762 & 0.7655 \\
\hline
\end{tabular}


Table 3

Measured conditioning and pellet exit temperatures $\left({ }^{\circ} \mathrm{C}\right)$, and $\beta$-glucanase activities in mash and pelleted feed samples

\begin{tabular}{|c|c|c|c|c|c|c|c|}
\hline \multirow{2}{*}{$\begin{array}{l}\text { Enzyme } \\
\text { dosage } \\
\left(\mathrm{g} \mathrm{kg}^{-1}\right)\end{array}$} & \multirow[t]{2}{*}{ Treatment } & \multicolumn{3}{|c|}{ In the conditioner } & \multirow{2}{*}{$\begin{array}{l}\text { Pellet exit } \\
\text { temperature }\end{array}$} & \multirow{2}{*}{$\begin{array}{l}\beta \text {-glucanase' } \\
\left(\text { IRVU kg }^{-1}\right)\end{array}$} & \multirow{2}{*}{$\begin{array}{l}\mathrm{CV}^{2} \\
(\%)\end{array}$} \\
\hline & & $\begin{array}{l}\text { Time } \\
(\min )\end{array}$ & $\begin{array}{l}\text { Target } \\
\text { temperature }\end{array}$ & $\begin{array}{l}\text { Measured } \\
\text { temperature }\end{array}$ & & & \\
\hline \multirow[t]{7}{*}{0} & \multicolumn{4}{|c|}{ NE control (mash) } & & $4.0 \pm 0$ & \\
\hline & $\mathrm{NE} 1^{3}$ & 0.5 & 75 & 74 & 78 & $2.5 \pm 0.7$ & \\
\hline & NE2 & 0.5 & 85 & 84 & 84 & $1.5 \pm 0.7$ & \\
\hline & NE3 & 0.5 & 95 & 90 & 94 & $1.5 \pm 0.7$ & \\
\hline & NE4 & 15 & 75 & 70 & 82 & $2.5 \pm 0.7$ & \\
\hline & NE5 & 15 & 85 & 77 & 83 & $2.0 \pm 0$ & \\
\hline & NE6 & 15 & 95 & 89 & 92 & $1.5 \pm 0.7$ & 28.0 \\
\hline \multirow[t]{7}{*}{1} & \multicolumn{4}{|c|}{ AO control (mash) } & & $23.5 \pm 3.5$ & \\
\hline & $\mathrm{AO}^{3}{ }^{3}$ & 0.5 & 75 & 74 & 81 & $15.0 \pm 1.4$ & \\
\hline & $\mathrm{AO} 2$ & 0.5 & 85 & 83 & 82 & $16.5 \pm 0.7$ & \\
\hline & $\mathrm{AO} 3$ & 0.5 & 95 & 91 & 82 & $4.5 \pm 2.1$ & \\
\hline & $\mathrm{AO} 4$ & 15 & 75 & 71 & 86 & $13.5 \pm 3.5$ & \\
\hline & AOS & 15 & 85 & 83 & 88 & $8.5 \pm 0.7$ & \\
\hline & AO6 & 15 & 95 & 91 & 88 & $3.5 \pm 0.7$ & 18.4 \\
\hline \multirow[t]{7}{*}{10} & \multicolumn{5}{|c|}{ AT control (mash) } & $271 \pm 9$ & \\
\hline & $\mathrm{AT}^{3}{ }^{3}$ & 0.5 & 75 & 75 & 81 & $185 \pm 7$ & \\
\hline & AT2 & 0.5 & 85 & 85 & 82 & $113 \pm 14$ & \\
\hline & AT3 & 0.5 & 95 & 93 & 83 & $36 \pm 7$ & \\
\hline & AT4 & 15 & 75 & 76 & 84 & $112 \pm 4$ & \\
\hline & AT5 & 15 & 85 & 85 & 85 & $71 \pm 5$ & \\
\hline & AT6 & 15 & 95 & 92 & 91 & $20 \pm 3$ & 9.2 \\
\hline \multicolumn{6}{|c|}{ Avizyme SX } & $23900 \pm 280$ & 1.2 \\
\hline
\end{tabular}

'Values are means $(n=2) \pm \mathrm{SD}$.

${ }^{2}$ Coefficient of variance percentage, average within each level of enzyme concentration (for NE, AO and AT $n=7$; for Avizyme SX $n=1$ ).

${ }^{3} \mathrm{NE}$, no enzyme added; $\mathrm{AO}$, enzyme added at $1 \mathrm{~g} \mathrm{~kg}^{-1}$; AT, enzyme added at $10 \mathrm{~g} \mathrm{~kg}^{-1}$.

was 4 IRVU $\mathrm{kg}^{-1}$ (Table 3). In the pelleted unsupplemented feeds, between 1.5 and 2.5 IRVU $\mathrm{kg}^{-1}$ was found, indicating significant inactivation even at the lowest temperatures. $\beta$-glucanase recovery in the supplemented mash feeds (AO$\mathrm{M}$ and AT-M) was complete. At the lower $\left(1 \mathrm{~g} \mathrm{~kg}^{-1}\right)$ inclusion rates, conditioning at 75,85 and $95^{\circ} \mathrm{C}$ for $30 \mathrm{~s}$ resulted in enzyme recoveries of $64 \%, 70 \%$ and $19 \%$ of the mash, respectively. Conditioning for $15 \mathrm{~min}$ at the three target temperatures $\left(75^{\circ} \mathrm{C}, 85^{\circ} \mathrm{C}\right.$ and $\left.95^{\circ} \mathrm{C}\right)$ resulted in enzyme activity recoveries of $57 \%$, $36 \%$ and $15 \%$, respectively, of the mash feed. The enzyme activity recoveries with Avizyme added at $10 \mathrm{~g} \mathrm{~kg}^{-1}$ and after conditioning at $75^{\circ} \mathrm{C}, 85^{\circ} \mathrm{C}$ and $95^{\circ} \mathrm{C}$ were respectively $68 \%, 42 \%$ and $13 \%$ of the mash when conditioning time was $30 \mathrm{~s}$ and 
$41 \%, 26 \%$ and $7 \%$ when conditioning time was $15 \mathrm{~min}$. The coefficient of variance $(\mathrm{CV})$ of the recovery values decreased generally with increasing enzyme concentration (Table 3). Average CV percentages of the NE, AO and AT samples were $28.0,18.4$ and 9.2, respectively, and that of the enzyme premix, 1.2.

\subsection{Broiler performance trial}

There were no significant interactions between enzyme, temperature and time for all parameters determined in the broiler experiment apart from an enzyme by temperature interaction for the parameter digesta viscosity. Consequently, main effects are given in Table 4 for all parameters except for viscosity.

Liveweight gain and feed efficiency improved linearly with increased levels of enzyme addition (Table 4). Furthermore, there was a significant quadratic liveweight gain and feed efficiency response to increased conditioning temperatures, indicating increasing enzyme activity loss with increased temperature. There was

Table 4

Liveweight gain $(\mathrm{g})$, feed intake $(\mathrm{g})$, feed:gain ratios, gut viscosities $(\mathrm{cPs})$ and vent pasting (\% of birds affected) at Day 19 of birds fed the experimental diets

\begin{tabular}{|c|c|c|c|c|}
\hline Treatment & $\begin{array}{l}\text { Liveweight } \\
\text { gain }\end{array}$ & $\begin{array}{l}\text { Feed } \\
\text { intake }\end{array}$ & $\begin{array}{l}\text { Feed:gain } \\
\text { ratio }\end{array}$ & $\begin{array}{l}\text { Vent } \\
\text { pasting }\end{array}$ \\
\hline \multicolumn{5}{|c|}{ Enzyme $\left(\mathrm{g} \mathrm{kg}^{-1}\right)$} \\
\hline 0 & 517 & 859 & 1.67 & 7.4 \\
\hline 1 & 545 & 840 & 1.55 & 3.4 \\
\hline 10 & 558 & 831 & 1.49 & 0.8 \\
\hline$P$-value & 0.0001 & 0.6397 & 0.0001 & 0.0200 \\
\hline \multicolumn{5}{|l|}{ Contrast } \\
\hline Linear & 0.0001 & 0.3557 & 0.0001 & 0.0055 \\
\hline Quadratic & 0.0986 & 0.8493 & 0.1177 & 0.7688 \\
\hline \multicolumn{5}{|c|}{ Temperature $\left({ }^{\circ} \mathrm{C}\right)$} \\
\hline 75 & 547 & 839 & 1.54 & 4.6 \\
\hline 85 & 556 & 851 & 1.53 & 1.9 \\
\hline 95 & 517 & 840 & 1.64 & 5.1 \\
\hline$P$-value & 0.0001 & 0.9165 & 0.0001 & 0.2554 \\
\hline \multicolumn{5}{|l|}{ Contrast } \\
\hline Linear & 0.0001 & 0.9530 & 0.0001 & 0.8068 \\
\hline Quadratic & 0.0042 & 0.6806 & 0.0045 & 0.1027 \\
\hline \multicolumn{5}{|l|}{ Time (min) } \\
\hline 0.5 & 544 & 851 & 1.57 & 1.7 \\
\hline 15 & 539 & 836 & 1.57 & 6.0 \\
\hline$P$-value & 0.6321 & 0.5587 & 0.6890 & 0.0130 \\
\hline \multicolumn{5}{|l|}{ Contrast } \\
\hline Linear & 0.6321 & 0.5587 & 0.6890 & 0.0130 \\
\hline
\end{tabular}


no difference in bird performance when feeds were conditioned at 75 and $85^{\circ} \mathrm{C}$. Conditioning time had no effect on bird performance and none of the treatments had any effect on feed intake.

\subsection{Vent pasting}

There was a significant negative linear response to enzyme supplementation on the vent pasting of birds (Table 4 ). There was a tendency towards a quadratic effect of conditioning temperature $(P=0.1027)$, positively correlated with the measured gut viscosities. Conditioning for 15 min significantly $(P=0.013)$ increased the incidence of vent pasting at 19 days of age compared with $30 \mathrm{~s}$ conditioning.

\subsection{Digesta viscosity}

There was no significant effect of conditioning time on digesta viscosity (data not shown). Pelleting by itself markedly increased digesta viscosity but owing to the high variation between the birds, this was not significant $(P=0.3724$, data not shown). Increasing pelleting temperatures resulted in a significant $(P=0.0392)$ quadratic response in birds fed the control diet (Table 5), whereas there was a linear response with enzyme supplemented feeds $(P<0.002)$, indicating reduced enzyme activity at higher temperatures. Digesta viscosity decreased linearly with increased enzyme inclusion rates at all conditioning temperatures employed $(P<0.0005)$.

\subsection{Enzyme activity in the small intestine}

With the azo-glucan method employed, it was not possible to reliably measure $\beta$-glucanase activity in digesta samples obtained from birds fed the unsupplemented diets (NE treatments). $\beta$-glucanase activity in samples obtained from

Table 5

Effect of temperature $\left({ }^{\circ} \mathrm{C}\right)$ and enzyme concentration $\left(\mathrm{g} \mathrm{kg}^{-1}\right)$ on digesta viscosity $(\mathrm{cPs})$

\begin{tabular}{|c|c|c|c|c|c|c|}
\hline & \multicolumn{3}{|c|}{ Temperature } & \multirow[t]{2}{*}{$P$-value } & \multicolumn{2}{|c|}{ Contrasts } \\
\hline & 75 & 85 & 95 & & Linear & Quadratic \\
\hline \multicolumn{7}{|l|}{ Enzyme } \\
\hline 0 & 31.3 & 16.7 & 29.1 & 0.2846 & 0.7689 & 0.0392 \\
\hline 1 & 5.4 & 8.6 & 17.7 & 0.0001 & 0.0001 & 0.1059 \\
\hline 10 & 2.9 & 3.8 & 6.0 & 0.0280 & 0.0012 & 0.3847 \\
\hline$P$-value & 0.0001 & 0.0044 & 0.0035 & & & \\
\hline \multicolumn{7}{|l|}{ Contrast } \\
\hline Linear & 0.0001 & 0.0004 & 0.0003 & & & \\
\hline Quadratic & 0.0087 & 0.5024 & 0.9719 & & & \\
\hline
\end{tabular}


Table 6

$\beta$-glucanase activity ( $\mathrm{U}$ per $1000 \mathrm{ml}$ supernatant) in the digesta of birds fed the AT diets

\begin{tabular}{lc}
\hline Treatment & $\beta$-glucanase \\
\hline AT1 $^{2}$ & $31.9 \pm 13.0$ \\
AT2 & $21.8 \pm 7.7$ \\
AT3 & $4.9 \pm 3.1$ \\
AT4 & $15.6 \pm 2.2$ \\
AT5 & $7.0 \pm 7.8$ \\
AT6 & $2.6 \pm 1.0$ \\
\hline
\end{tabular}

${ }^{1}$ Values are means $(n=4) \pm \mathrm{SD}$.

${ }^{2}$ Enzyme (Avizyme SX) added at $10 \mathrm{~g} \mathrm{~kg}^{-1}$.

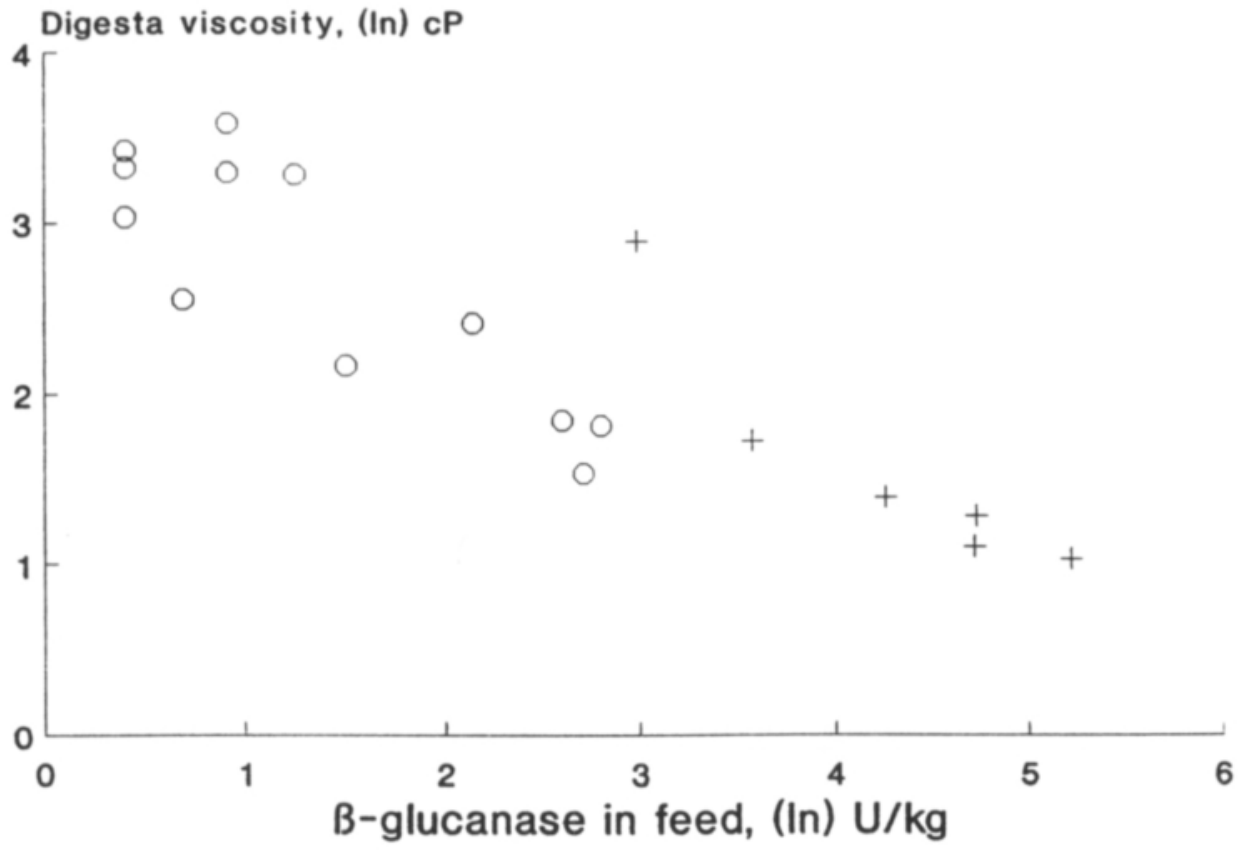

Fig. 1. Relationship between the logarithm of dietary $\beta$-glucanase activity and digesta viscosity: + , AT $\left(r^{2}=0.957\right) ; \mathrm{O}, \mathrm{NE}$ and $\mathrm{AO}\left(r^{2}=0.746\right)$; for the whole data set $r^{2}=0.855$.

birds fed Avizyme SX at $10 \mathrm{~g} \mathrm{~kg}^{-1}$ (AT treatments) feed could be reliably measured and the results are presented in Table 6. Enzyme activity decreased with increasing conditioning temperature and time.

3.7. Enzyme activity in feed and digesta in relation to digesta viscosity and bird performance

Plotting gut viscosity against dietary $\beta$-glucanase activity on a logarithmic scale revealed a high correlation between these parameters $\left(r^{2}=0.855\right.$, Fig. 1). How- 


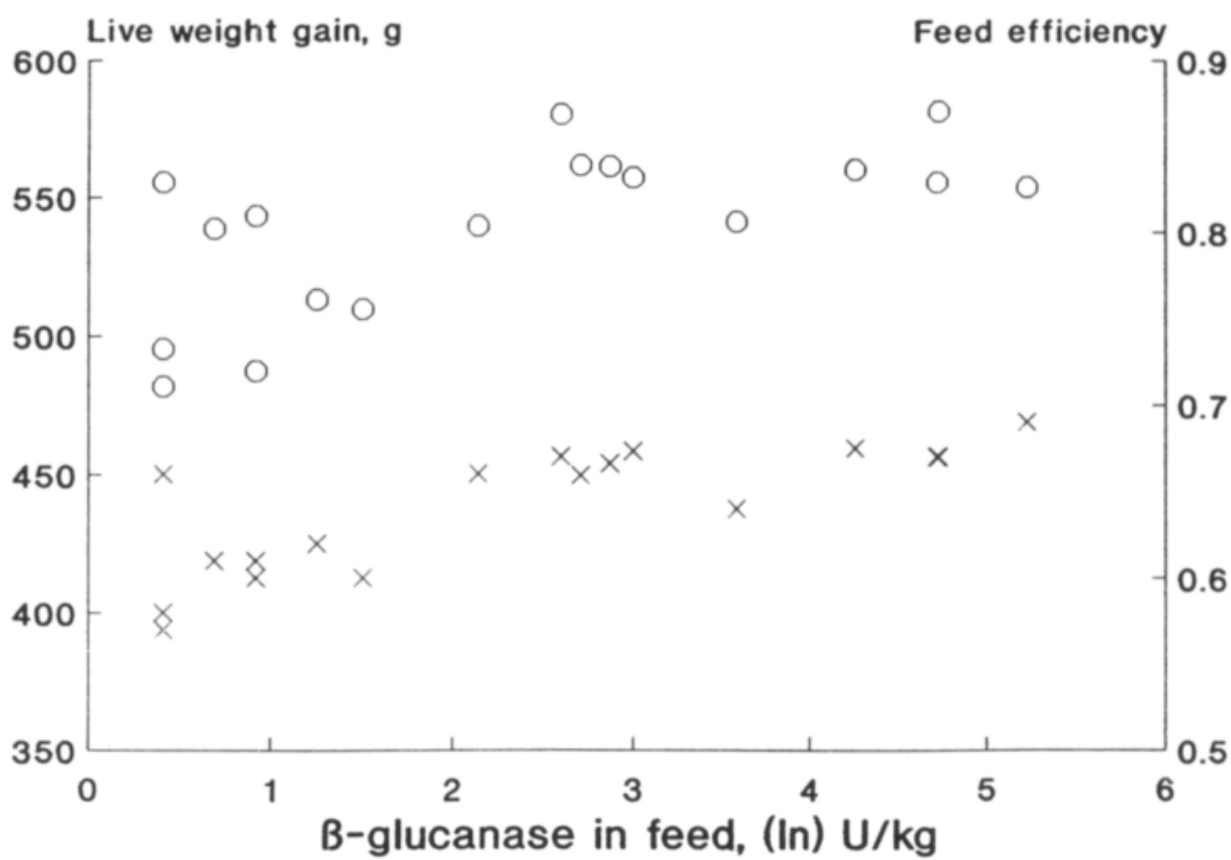

Fig. 2. Relationship between the logarithm of dietary $\beta$-glucanase activity and chick performance. $O$, weight gain $\left(r^{2}=0.431\right) \times$, feed efficiency $\left(r^{2}=0.639\right)$.

ever, at the low dietary $\beta$-glucanase concentrations (NE and AO treatments), the correlation was lower $\left(r^{2}=0.746\right)$ compared with high $\beta$-glucanase concentration $\left(r^{2}=0.957\right)$. Plotting weight gain and feed efficiency against dietary $\beta$-glucanase activity on a linear scale gave $r^{2}$ values of 0.188 and 0.372 , respectively. By changing the $\beta$-glucanase values to their logarithms, $r^{2}$ values of 0.431 and 0.639 were obtained for weight gain and feed efficiency, respectively (Fig. 2). Digesta $\beta$-glucanase activity correlated well with digesta viscosity $\left(r^{2}=0.677\right.$, Fig. $3)$ and even better with the $\beta$-glucanase activity in feed $\left(r^{2}=0.948\right.$, slope 0.183 , Fig. 4).

\subsection{Gut viscosity in relation to bird performance}

The slope of the relationship between digesta viscosity and liveweight gain was $-2.13\left(r^{2}=0.624\right)$ and between digesta viscosity and feed conversion efficiency $-0.00267\left(r^{2}=0.616\right.$, Fig. 5$)$. When correlations were calculated for the values obtained with the lower enzyme concentrations (NE and AO treatments) $r^{2}$ values for weight gain was 0.566 and for feed efficiency 0.467 . At the higher enzyme concentrations (AO and AT treatments) the $r^{2}$ value for weight gain was 0.442 and for feed efficiency 0.352 . 


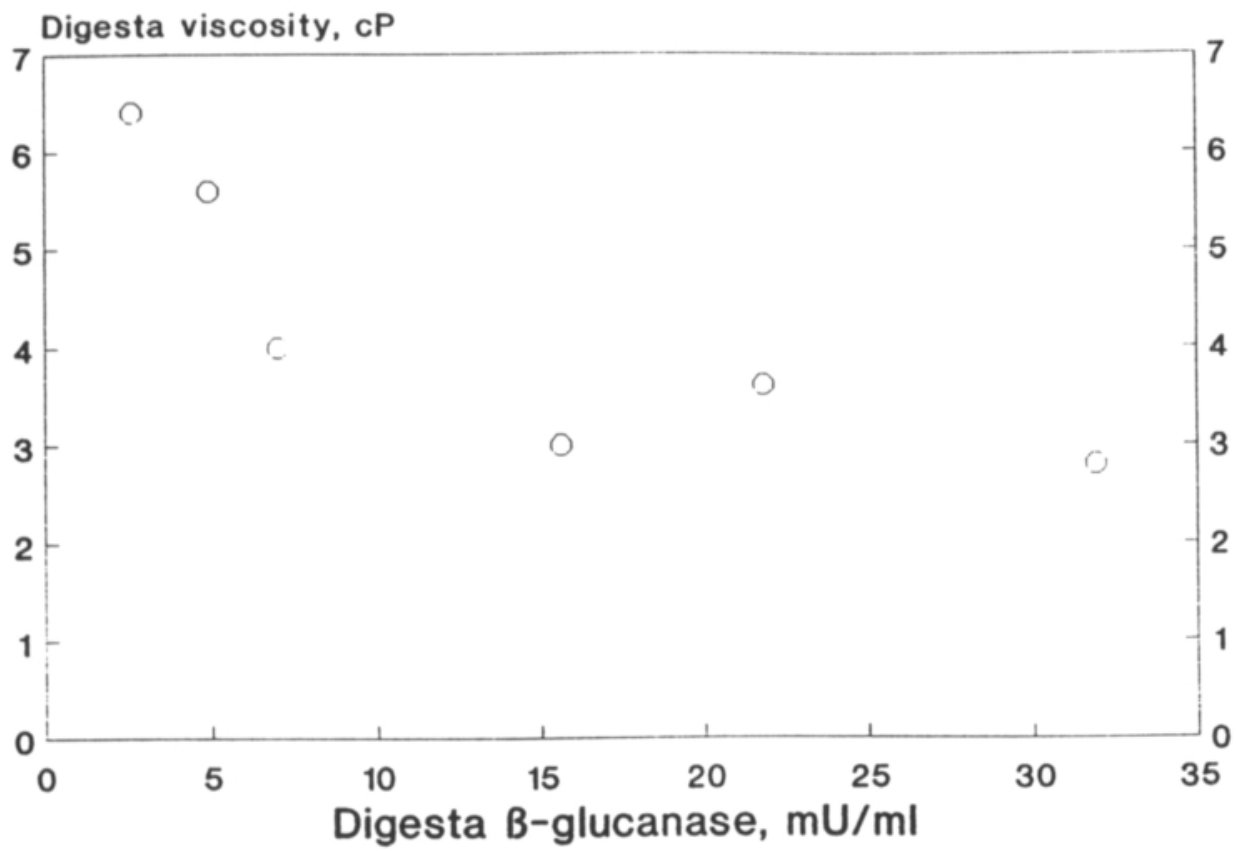

Fig. 3. Relationship between $\beta$-glucanase activity in digesta and digesta viscosity: $O$, AT treatment means $\left(r^{2}=0.677\right)$.

Digesta B-glucanase, $\mathrm{mU} / \mathrm{ml}$

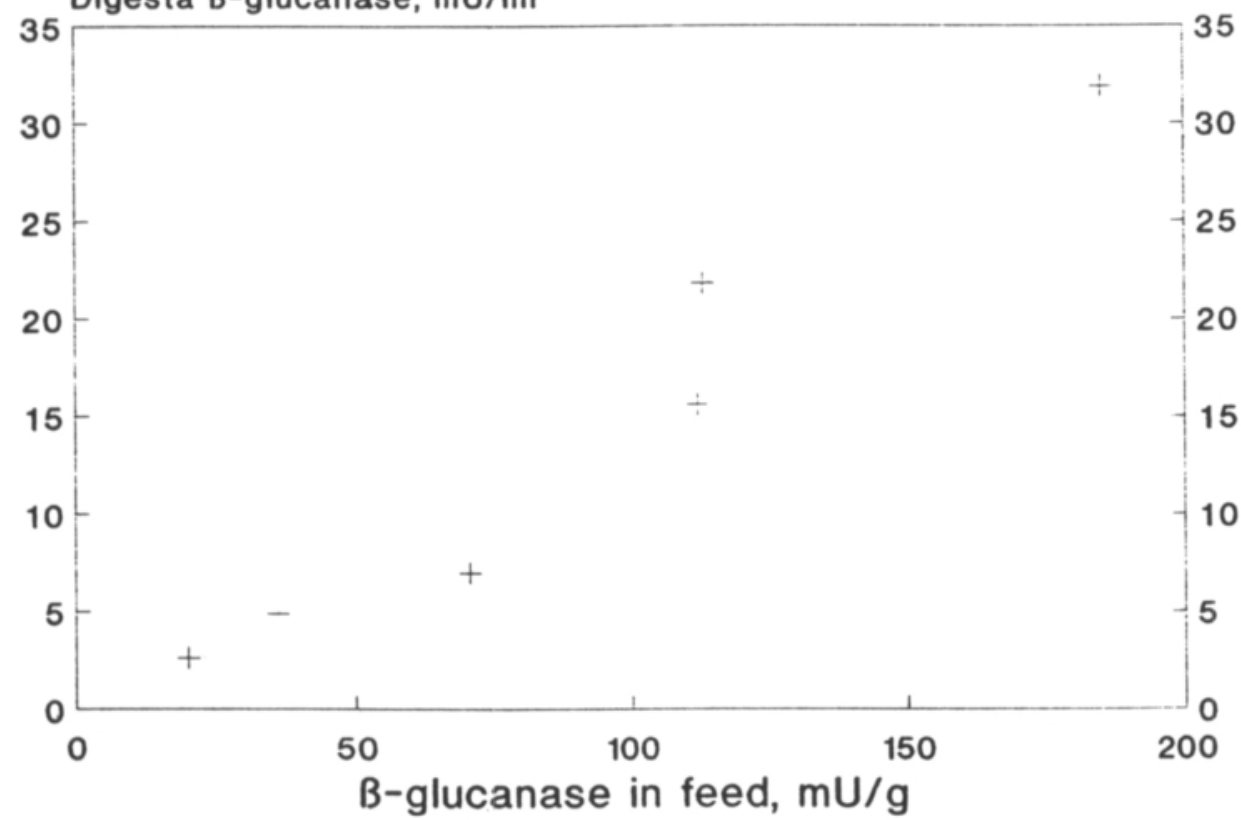

Fig. 4. Relationship between $\beta$-glucanase activity in feed and digesta: + , AT treatment means $\left(r^{2}=0.948\right)$. 


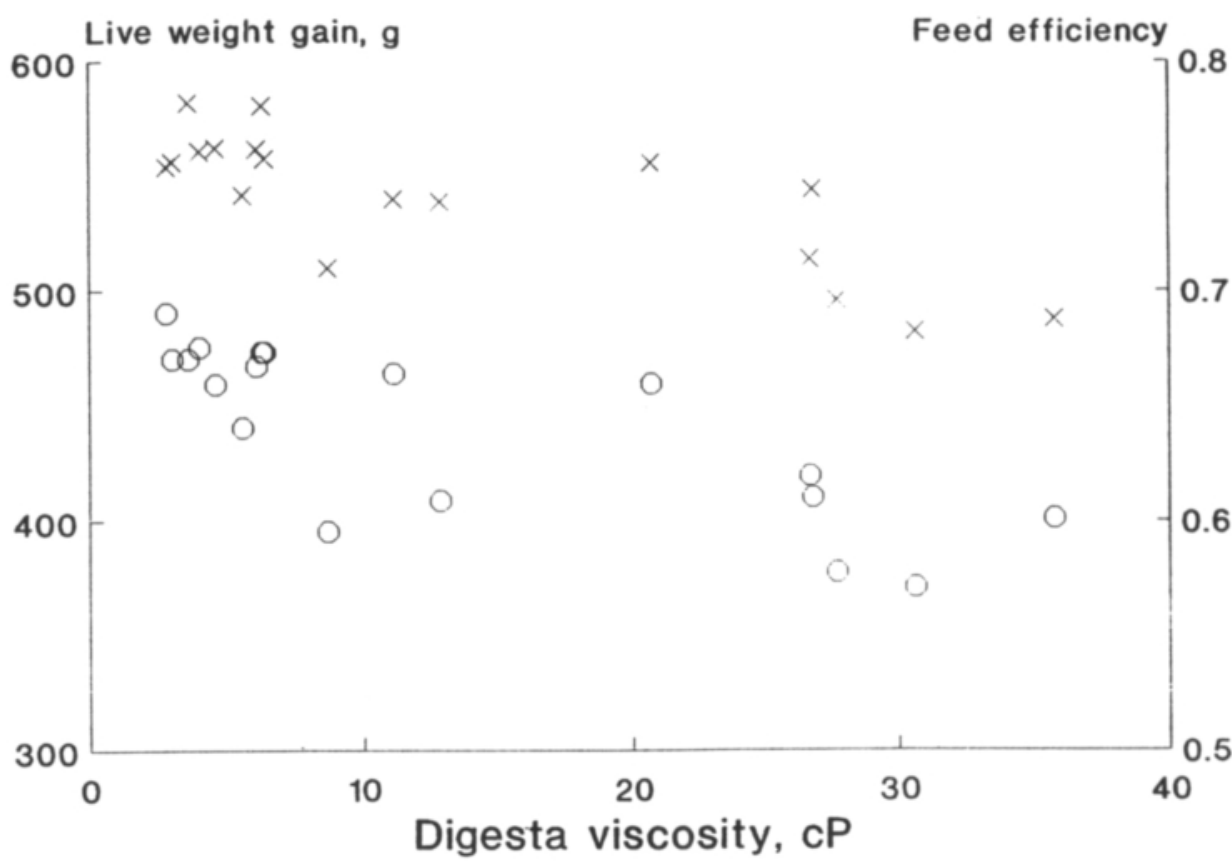

Fig. 5. Relationship between digesta viscosity and weight gain $(X)$ and feed efficiency $(O)$ in broiler chickens fed a barley-based diet supplemented with Avizyme SX at 0,1 and $10 \mathrm{~g} \mathrm{~kg}^{-1}$ and pelleted after conditioning at 75,85 and $95^{\circ} \mathrm{C}$ for either 0.5 or $15 \mathrm{~min}: \times$, weight gain $\left(r^{2}=0.624\right)$; $\mathrm{O}$, feed efficiency $\left(r^{2}=0.616\right)$.

\section{Discussion}

Feed intake of the birds was not influenced by either enzyme supplementation or conditioning temperature, which would suggest that digesta viscosity was not high enough to influence the rate of feed passage (Salih et al., 1991; Bedford and Classen, 1992). There was a linear effect of enzyme supplementation on feed efficiency and liveweight gain. These responses are in accordance with those reported by Bedford and Classen (1992) feeding rye- and wheat-based feeds to broiler chickens. They found a high correlation between digesta viscosity and these two performance parameters, indicating that intestinal viscosity has an important role in determining the performance of broilers fed diets with high soluble dietary fibre content. Increased viscosity is known to depress nutrient diffusion in vitro (Fengler and Marquardt, 1988). This would be expected to reduce absorption in the small intestine, thus depressing chick performance. In the present experiment, there was a relatively high correlation between digesta viscosity and chick performance (Fig. 5), with slope values close to those reported by Bedford and Classen (1992) feeding rye- and wheat-based diets to broiler chickens. The results from the present experiment, where barley was used as the main source of NSP, provide further evidence that it is not the chemical composition of the sol- 
uble NSP fraction per se but the viscosity it creates in the lumen that causes the deterioration in the performance of broiler chicks. The quadratic response in weight gain and feed utilisation due to increasing conditioning temperatures indicates that the negative effect of temperature had not been reached at $85^{\circ} \mathrm{C}$, suggesting that the enzyme was stable up to this temperature as far as these two parameters are concerned. Conditioning time did not influence any of the performance parameters, suggesting that once the target temperature was achieved it could be maintained for $15 \mathrm{~min}$ with no additional positive or negative effects. This strongly indicates that conditioning temperature is of great importance, with little effect of time. Interestingly, conditioning at $85^{\circ} \mathrm{C}$ resulted in the best performance, lowest digesta viscosity values and lowest incidence of vent pasting of birds fed the unsupplemented diets. It is possible that these processing conditions were the most optimal, resulting in a combination of the highest degree of starch gelatinisation and least degree of formation of Maillard products and resistant starch.

Digesta viscosity of birds fed the unsupplemented diets showed a quadratic response to increased conditioning temperatures, whereas there was a linear effect, and a tendency $(P=0.1059)$ towards a quadratic effect of temperature for the diets with the lower concentration of the enzyme. These data would suggest that the stability of the enzyme was better between 75 and $85^{\circ} \mathrm{C}$ than between 85 and $95^{\circ} \mathrm{C}$. At the highest level of enzyme inclusion there was a linear effect of temperature, although values were low even at $95^{\circ} \mathrm{C}$. This would indicate partial inactivation, but due to the overwhelming concentration of enzyme, there was still sufficient activity even after conditioning at $95^{\circ} \mathrm{C}$ to maintain low digesta viscosities. With conditioning at $75^{\circ} \mathrm{C}$ there was a quadratic response to enzyme supplementation, indicating that increasing the enzyme concentration ten-fold was of marginal benefit. At higher conditioning temperatures, enzyme supplementation decreased digesta viscosity in a linear fashion, suggesting that the benefits from increasing the enzyme concentration were more apparent.

Digesta viscosity and vent pasting values seemed to correspond well with each other in terms of the response to enzyme and temperature. However, the incidence of vent pasting was significantly increased when using a conditioning time of $15 \mathrm{~min}$ compared with $30 \mathrm{~s}$, whereas no such effect was observed for digesta viscosity. It is possible that long-term conditioning causes components of the NSP fraction to be solubilised further down in the GI tract of the bird, so that digesta viscosity in the proximal part of the small intestine is not affected but water content and stickiness of excreta is increased. McCracken et al. (1992) reported both decreased excreta dry matter content and increased digesta viscosity when feeding broiler chickens with feeds pelleted after conditioning at $85^{\circ} \mathrm{C}$ for $15 \mathrm{~min}$ compared with cold pelleted feeds. In this experiment, digesta from the entire small intestine was collected for the viscosity measurements, which could explain the discrepancy between this and the present experiment in terms of digesta viscosity responses.

Apparent loss of enzyme activity during pelleting has been reported for phytase (Jongbloed and Kemme, 1990) and hemicellulases such as glucanase and xylan- 
ase (Pickford, 1992). These results were based on in vitro measurements using conventional enzyme activity assay methods. The results from the present experiment also show significant loss of $\beta$-glucanase activity after pelleting when measured using the in vitro viscosimetric method. Despite this, enzyme supplementation significantly improved broiler performance, suggesting either that there was still sufficient enzyme activity in the feed or that the in vitro assay method underestimated the actual $\beta$-glucanase activity. Conditioning the diets at 75 and $85^{\circ} \mathrm{C}$ resulted in almost identical overall bird performance, but both liveweight gain and feed utilisation were significantly worse after conditioning at $95^{\circ} \mathrm{C}$ before pelleting.

Dietary $\beta$-glucanase correlated linearly with digesta $\beta$-glucanase to a high degree with a slope of 0.183 (Fig. 4). This means, for each unit increase of dietary $\beta$-glucanase, the $\beta$-glucanase activity in the upper small intestine increases by 0.183 . By assuming the dry matter content of the digesta to be between 16 and $18 \%$ (Bedford et al., 1991), a five-fold dilution of the dietary $\beta$-glucanase activity is to be expected. This comes very close to the factor of 0.183 and indicates more or less full recovery of the measured activity of the feed in the small intestine. Moreover, there was a high linear correlation between digesta $\beta$-glucanase activity and digesta viscosity (Fig. 3), which in turn correlated linearly with both weight gain and feed efficiency of the broiler chickens. Based on the above, one would assume that dietary $\beta$-glucanase would also correlate with the chick performance parameters. However, this was not the case until the dietary $\beta$-glucanase values had been transformed to their logarithms (Fig. 2). This decreases the discriminatory power of this method compared with digesta viscosity.

It would appear, based on the relatively high correlation between $\beta$-glucanase activity in feed and digesta viscosity (Fig. 1), that the cellulose binding domain (CBD) effect on interfering with in-feed analysis was not evident in this experiment. It is possible that the recovery of $\beta$-glucanase in the extraction was high and the amount of enzyme extracted represents the amount of active $\beta$-glucanase in the feed. The binding power of the CBD is variable and that of some cellulases of, for example Trichoderma ssp. can be quite low (Poole et al., 1991). Hence this may allow a high recovery even after heat treatment.

There was a ten-fold higher activity measured in the AT than in the AO feeds, indicating that the assay is linear over this range. The coefficient of variance (CV) of the $\beta$-glucanase recovery values decreased rapidly with increased levels of enzyme concentration of the diets. Thus, with the enzyme added at $1 \mathrm{~g} \mathrm{~kg}^{-1}, \mathrm{CV}$ decreased from 28.0 (unsupplemented diets) to $18.2 \%$ and further to $9.2 \%$ when the enzyme was added at $10 \mathrm{~g} \mathrm{~kg}^{-1}$. This would indicate that the assay method employed can be used for 'in-feed' analysis to measure $\beta$-glucanase activity at commercially used concentrations. It should be emphasised, however, that absolute $\beta$-glucanase activity in feed is not necessarily a good predictor of broiler performance, since plotting dietary $\beta$-glucanase activity against liveweight gain and feed efficiency coefficients gave very low $r^{2}$ values. By using the $\beta$-glucanase values on a logarithmic scale, correlations increased considerably and the value for feed efficiency was relatively high $(0.651)$. 
Pelleting diets for broiler chickens has usually resulted in improved performance (Inborr and Graham, 1991; Teigte et al., 1991), although it has been shown that pelleting increases the proportion of soluble NSP in the ileal digesta of pigs (Graham et al., 1988), which is likely to increase digesta viscosity and therefore could affect chick performance (Choct and Annison, 1992). In the present experiment, pelleting the basal diet at $75^{\circ} \mathrm{C}$ numerically increased digesta viscosity and there was an increased incidence of vent pasting with the long-term conditioning. This may be explained by the increased solubility of $\beta$-glucans observed as a result of pelleting. Inborr and Graham (1991) observed a greater response to enzyme supplementation of pelleted than mash feeds when fed to broiler chickens, suggesting that the enzymes had maintained their activity and a possible positive interaction between exogenous enzymes and pelleting. Similar results were reported by Teigte et al. (1991) who found that both pelleting and micronisation of rye increased the chick performance response to pentosanase supplementation compared with untreated rye, indicating that heat treatment renders the antinutritive substances in rye more accessible to the enzyme.

Based on these results it can be concluded that the higher the conditioning temperature and the longer the conditioning time, the lower the enzyme recovery and apparent activity when measured by in vitro methods. Conditioning at $85^{\circ} \mathrm{C}$ before pelleting did not reduce enzyme activity compared with $75^{\circ} \mathrm{C}$ based on bird performance, whereas significant inactivation occurred at $95^{\circ} \mathrm{C}$. The high correlation between $\beta$-glucanase activity in feed and digesta viscosity on the one hand, and gut viscosity and bird performance on the other hand, suggests that both the in vitro and in vivo methods employed in this study give a good estimate of enzyme survivability through pelleting.

\section{Acknowledgements}

The authors would like to thank John Bouwman and Willem van de Veen, Trouw International BV, Putten, Netherlands, for arranging and carrying out the pelleting of the experimental feeds and Dr. Walter Michie at the Scottish Agricultural College in Aberdeen (Craibstone Estate), Scotland, for supervising the broiler performance experiment. The $\beta$-glucanase activity measurements (feed samples) carried out by Jari Puhakka at the Cultor Technology Centre, and by Dr. Peter Hotten and Yvonne Turnbull at Rowett Research Services, Aberdeen, Scotland (digesta samples) are highly appreciated. This experiment was funded by Finnfeeds International, Wiltshire, UK.

\section{References}

Åman, P. and Graham, H., 1987. Analysis of total and insoluble mixed-linked (1-3), (1-4)- $\beta$-D-glucans in barley and oats. J. Agric. Food Chem., 35: 704-709. 
Ảman, P. and Hesselman, K., 1984. Analysis of starch and other main constituents of cereal grains. Swed. J. Agric. Res., 14: 135-142.

Association of Official Analytical Chemists, 1990. Official Methods of Analysis, 15th edn. AOAC, Washington, DC.

Atkinson, T., Fowler, V.R., Garten, G.A. and Lough, A.K., 1972. A rapid method for accurate determination of lipid. Analyst, 97: 562-568.

Bathgate, G.N., 1979. The determination of endo- $\beta$-glucanase activity in malt. J. Inst. Brew., 85: $92-$ 94.

Bedford, M.R. and Classen, H., 1992. Reduction of intestinal viscosity through manipulation of dietary rye and pentosanase concentration is effected through changes in the carbohydrate composition of the intestinal aqueous phase and results in improved growth rate and feed conversion. J. Nutr., 122: 560-569.

Bedford, M.R., Classen, H.L. and Campbell, G.L., 1991. The effect of pelleting, salt, and pentosanase on the viscosity of intestinal contents and the performance of broilers fed rye. Poult. Sci., 70: 1571-1577.

Chesson, A., 1987. Supplementary enzymes to improve the utilisation of pig and poultry diets. In: W. Haresign and D.J.A. Cole (Editors), Recent Advances in Animal Nutrition. Butterworths, London, pp. 71-89.

Choct, M. and Annison, G., 1992. Anti-nutritive effect of wheat pentosans in broiler chickens: roles of viscosity and gut microflora. Br. Poult. Sci., 33: 821-834.

Dierick, N.A., 1989. Biotechnology aids to improve feed and feed digestion: enzymes and fermentation. Arch. Anim. Nutr. Berlin, 39: 241-261.

Fengler, A.S. and Marquardt, R.R., 1988. Water-soluble pentosans from rye: II. Effects on rate of dialysis and on the retention of nutrients by the chick. Cereal Chem., 65: 298-302.

Godfrey, T. and Reichelt, J. (Editors), 1983. Industrial Enzymology. The Application of Enzymes in Industry. Macmillan Publishers, Chippenham, UK, $582 \mathrm{pp}$.

Graham, H., Fadel, J.G., Newman, C.W. and Newman, R.K., 1988. Effect of pelleting and $\beta$-glucanase supplementation on the ileal and faecal digestibility of a barley-based diet in the pig. J. Anim. Sci., 67:1293-1298.

Inborr, J., Bedford, M.R. and Graham, H., 1993. Stability and mode of action of poultry feed enzymes in diets based on wheat and barley. Proc. Australian Poultry Science Symp., The WPSA (Australian Branch), University of Sydney, Sydney, N.S.W., Vol. 5, pp. 53-56.

Inborr, J. and Graham, H., 1991. Effect of enzyme supplementation of wheat-based diets on the performance of broiler chickens. Proc. Australian Poultry Science Symp., The WPSA (Australian Branch ), University of Sydney, Sydney, N.S.W., pp. 50-55.

Jongbloed, A.W. and Kemme, P.A., 1990. Effect of pelleting mixed feeds on phytase activity and the apparent absorbability of phosphorus and calcium in pigs. Anim. Feed Sci. Technol., 28: 233-242.

Ministry of Agriculture, Fisheries and Food, 1985. Analysis of Agricultural Materials. Reference Book 427, MAFF, p. 36.

McCracken, K.J., Urquhart, R. and Bedford, M.R., 1993. Effect of heat treatment and enzyme supplementation of barley-based diets on performance of broiler chickens. Proc. Nutr. Soc., in press.

Pickford, J.R., 1992. Effects of processing on the stability of heat labile nutrients in animal feeds. In: P.C. Garnsworthy, W. Haresign and D.J.A. Cole (Editors), Recent Advances in Animal Nutrition. Butterworth-Heinemann, Oxford, pp. 177-192.

Poole, D.M., Durrant, A.J., Hazlewood, G.P. and Gilbert, H.J., 1991. Characterisation of hybrid proteins consisting of the catalytic domains of Clostridium and Ruminococcus endoglucanases, fused Pseudomonas non-catalytic cellulose-binding domains. Biochem. J., 279: 787-792.

Salih, M.E., Classen, H.L. and Campbell, G.L., 1991. Response of chickens fed hulless barley to dietary $\beta$-glucanase at different ages. Anim. Feed Sci. Technol., 25: 193-200.

Statistical Analysis Systems Institute, 1982. SAS Users Guide: Statistics. SAS Institute, Cary, NC.

Teigte, D.A., Campbell, G.L., Classen, H.L. and Thacker, P.A., 1991. Heat pretreatment as a means of improving the response to dietary pentosanase in chicks fed rye. Can. J. Anim. Sci., 71: 507513. 


\title{
Stability of feed enzymes in physiological conditions assayed by in vitro methods
}

\author{
JOHAN INBORR and ANNE GRÖNLUND
}

INBORR, J. \& GRÖLUND, A. 1993. Stability of feed enzymes in physiological conditions assayed by in vitro methods. Agric. Sci. Finl. 2: 125-132. (Finnfeeds International Ltd., Market House, High Street, Marlborough, Wiltshire SN8 1AA, United Kingdom and Cultor Ltd., Technology Centre, FIN-02640 Kantvik, Finland.)

A series of in vitro incubations were carried out to investigate the stability of two enzyme preparations in conditions similar to those in the upper gastrointestinal tract of monogastric animals. The two enzyme products, one crude xylanase from Trichoderma longibrachiatum (Multifekt $\mathrm{K}$ ) and the other a specifically manufactured feed enzyme (Avizyme SX), were subjected to incubations at low and neutral $\mathrm{pH}$ with and without proteolytic enzymes (pepsin and pancreatin). Wheat gluten was employed together with the crude xylanase to investigate its potential as a stabilising agent. Due to the buffering effect of Avizyme $\mathrm{SX}^{\circledast}$, incubations were carried out with $(\mathrm{pH} 2.5)$ and without $(\mathrm{pH} 3.2)$ addition of either citric or hydrochloric acid. Incubation of the crude xylanase at low $\mathrm{pH}$ followed by incubation at neutral $\mathrm{pH}$ resulted in negligible loss of xylanase activity whereas $\beta$-xylosidase recovery fell to 57 per cent of the initial value $(\mathrm{P}<0.05)$. Addition of wheat gluten resulted in full recovery of $\beta$-xylosidase. The recoveries of both $\beta$-glucanase and $x y l a n a s e$ were significantly $(\mathrm{P}<0.05)$ lower than the initial values after incubation of Avizyme $\mathrm{SX}^{\circledast}$ in $\mathrm{pH}$ 2.5. However, with no $\mathrm{pH}$ adjustment ( $\mathrm{pH}$ 3.2) the recoveries were significantly higher ( $\mathrm{P}<0.05$ for $\beta$-glucanase and $\mathrm{P}<0.10$ for $x y l a n a s e)$. The results from the pepsin and pancreatin incubations showed similar trends as the ones of the $\mathrm{pH}$ stability experiments. Consequently, gluten addition and no $\mathrm{pH}$ adjustment gave the highest enzyme activity recoveries.

The results suggest that partial enzyme inactivation may occur due to the low $\mathrm{pH}$ and proteolytic activities and hence in the GI-tract of monogastrics. Feeds and feedstuffs can due to their buffering capacity and possibly by providing substrates for the enzymes markedly reduce the rate of inactivation. Results from a number of pig and poultry experiments appear to support this assumption. In vivo recovery measurements using animal models are needed to substantiate this.

Key words: xylanase, $\beta$-glucanase, $\beta$-xylosidase, wheat gluten, enzyme survivability, $\mathrm{pH}$, pepsin, pancreatin, Multifect $\mathrm{K}$, Avizyme $\mathrm{SX}^{\oplus}$.

\section{Introduction}

Since the early 1980's the use of enzymes in animal feeds has received much attention both in the academic and commercial worlds. There is now a considerable amount of published work showing the response in animal performance to enzyme supplementation of feeds, which has been extensively reviewed by CHESSON (1987) and DIERICK (1990). With increased commercial use of feed enzymes stability has become a frequently debated issue. In particular, enzyme stability during feed manufac- 
turing, due to the different heat treatments (pelleting, expansion, extrusion etc.) now being employed in the feed industry, has caused some concern. Furthermore, once the enzymes enter into the gastrointestinal tract, they are subjected to a range of conditions that can cause inactivation. Firstly, gastric $\mathrm{pH}$ may be as low as 1, but usually around 2 in an empty stomach, with rapid increase to between 4 and 5 as ingested food arrives (KIDDER and MANNERS 1978). Keeping in mind that enzymes are proteins and, therefore, subject to proteolysis, low $\mathrm{pH}$ in combination with pepsin would appear to be a potential hazard for the enzyme molecules. Secondly, the pancreatic proteases e.g. trypsin and chymotrypsin represent a major threat to the enzymes due to their abundance and high activity in duodenum.

Cellulases and hemicellulases are the most commonly used enzymes in feed applications. These are mainly microbial enzymes produced by different fungi and bacteria. In general, the inherent heat stability of mesophilic microbial enzymes is poor, although there are considerable differences between enzymes from different sources in this respect (GODFREY and REICHELT 1983). Through modern biotechnology a number of stabilisation methods have been developed. For example, it is a known fact that substrates and inhibitors that bind specifically to the native conformation of an enzyme will increase the stability (PACE 1990). This method of stabilisation is called immobilisation and has been shown by SiMONS and GEORGATSOS (1990) to decrease heat inactivation of barley $\beta$ glucosidase. Other promising stabilisation methods involve adding crosslinks (disulfide bonds) to, substituting amino acids (PACE 1990) and crystallisation of the enzyme proteins (ST. CLAIR and NAVIA 1992). Furthermore, DE CORDT et al. (1992) found that polyols and carbohydrates are powerful stabilisers for both dissolved and immobilised $B$. licheniformis $\alpha$-amylase.

A series of in vitro experiments were designed to investigate the survivability of a few main activities of two enzymes subjected to conditions similar to those prevalent in the digestive tract of pigs and poultry. Two enzyme preparations, one crude and one specifically manufactured feed enzyme prod- uct, were employed. Xylanase and B-xylosidase activities of the crude enzyme preparation and B-glucanase and xylanase of the feed enzyme product were investigated.

\section{Material and methods}

A liquid crude xylanase preparation (Multifect K, Genencor International Ltd., Helsinki, Finland) from a Trichoderma longibrachiatum fermentation and a stabilised (liquid enzymes adsorbed and dried onto a wheat-based carrier; Patent FI 77359) commercial feed enzyme product (Avizyme $\mathrm{SX}^{\circledR}$, Finnfeeds International Ltd., Marlborough, Wiltshire, United Kingdom) containing $\beta$-glucanase and xylanase from Trichoderma longibrachiatum were subjected to treatments in conditions similar to those in the stomach (proventriculus) and small intestine of pigs and poultry. A schematic descriptions of the incubation procedure employed is presented in Figure 1.

\section{Incubation in low and neutral pH}

The conditions employed in these incubations were identical with those described below with the exception that no pepsin and pancreatin were used.

\section{Incubation with pepsin and pancreatin}

\section{Crude xylanase preparation}

$20 \mathrm{ml}$ of pepsin solution (Merck 7189), containing 0.25 protease units (haemoglobin, $\mathrm{pH} 1.2,25^{\circ} \mathrm{C}$ ) per ml, in 0.1 M McIlvaine's buffer (pH 2.5) was equilibrated at $40^{\circ} \mathrm{C} .10 \mathrm{ml}$ of xylanase solution in McIlvaine's buffer ( $1 \mathrm{ml}$ xylanase $/ 50 \mathrm{ml}$ buffer) was added and the solution diluted with buffer to 50 $\mathrm{ml}$ followed by incubation at $40^{\circ} \mathrm{C}, \mathrm{pH} 2.5$ for 30 minutes. The reaction was stopped in an ice/water bath immediately after incubation. $\mathrm{pH}$ was adjusted 


\section{pH stability Pepsin/pancreatin stability}

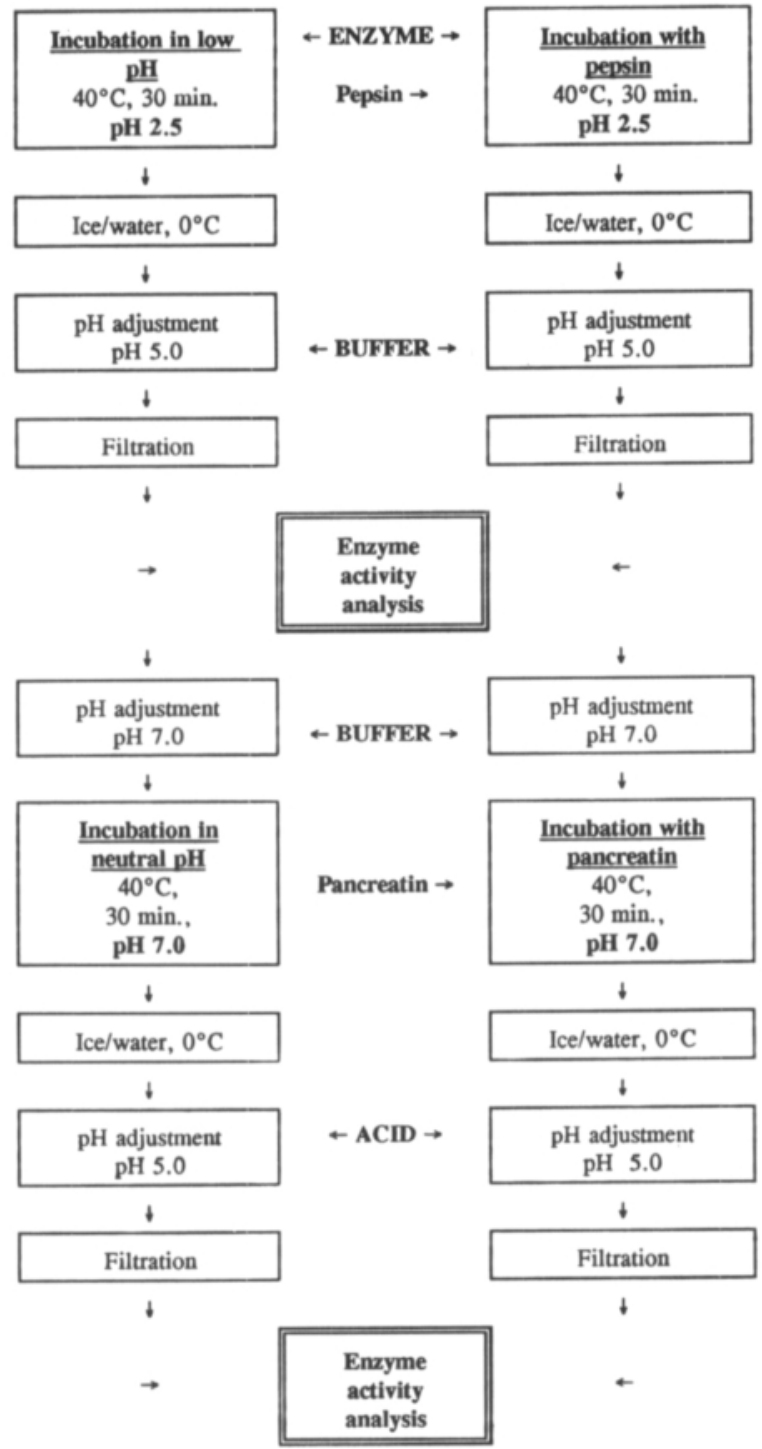

Fig. 1. Flow chart diagramme of the incubations.

with $0.5 \mathrm{M} \mathrm{Na}_{2} \mathrm{HPO}_{4}$ to 5.0 and the final volume was $100 \mathrm{ml}$. Xylanase and $\beta$-xylosidase activities were measured. The pepsin treated sample $(10 \mathrm{ml})$ was then adjusted to $\mathrm{pH} 7.0$ with $0.5 \mathrm{M} \mathrm{Na}_{2} \mathrm{HPO}_{4}$. $30 \mathrm{ml}$ of pancreatin solution (Merck 7230), containing 30 protease units per $\mathrm{ml}$, in Mcllvaine's buffer ( $\mathrm{pH} 7.0$ ), was added, and the solution diluted to 50 $\mathrm{ml}$ and adjusted to $\mathrm{pH} 7.0$ with McIlvaine's buffer.
The solution was incubated at $40^{\circ} \mathrm{C}$ for 30 minutes, after which time the reaction was stopped in an ice/water bath. The $\mathrm{pH}$ was adjusted to 5.0 by 0.5 $\mathrm{M}$ citric acid and xylanase and $\beta$-xylosidase activities measured.

A parallel incubation was carried out with wheat gluten $(2 \% \mathrm{w} / \mathrm{v})$ solubilised in a $\mathrm{NaCl}$ solution $(0.9 \% \mathrm{w} / \mathrm{v})$ as a stabiliser. When wheat gluten was 
used, samples were filtered through fibre glass filter paper before enzyme activity analysis.

\section{Commercial feed enzyme}

Two proteolysis procedures were carried out. In the first one, the $\mathrm{pH}$ was kept constant at 2.5 by addition of $6 \mathrm{~N} \mathrm{HCl}$, whereas in the second one no acid was added during the pepsin treatment, and the $\mathrm{pH}$ rose to 3.2 (buffering effect of the feed enzyme product).

$20 \mathrm{~g}$ feed enzyme premix was suspended in 0.1 M McIlvaine's buffer ( $\mathrm{pH} 2.5$ ) and the $\mathrm{pH}$ was either maintained at 2.5 by acid $(6 \mathrm{~N} \mathrm{HCl})$ addition or allowed to rise due to the buffering capacity of the feed enzyme product (parallel incubation). 10 $\mathrm{ml}$ pepsin solution was added to give a final volume of $70 \mathrm{ml}$. The $\mathrm{pH}$ was adjusted after incubation to 5.0 using $2.5 \mathrm{M} \mathrm{NaOH}$ and samples were taken for enzyme activity analysis ( $\beta$-glucanase and xylanase) after filtration through fibre glass filter paper.

The procedure continued with $70 \mathrm{ml}$ unfiltered pepsin-treated sample, employing the same conditions as with the crude xylanase preparation but without addition of wheat gluten. $15 \mathrm{ml}$ pancreatin solution in $0.1 \mathrm{ml}$ Mcllvaine's buffer ( $\mathrm{pH} 7.0$ ) was added giving a volume of $85 \mathrm{ml}$ during the incubation. After the $\mathrm{pH}$ adjustment $(15 \mathrm{ml} 2 \mathrm{M}$ citric acid) the final volume was $100 \mathrm{ml}$. $\beta$-glucanase and xylanase activities were measured after filtration.

\section{Enzyme activity analysis}

$\beta$-glucanase (EC 3.2.1.6; endo- $\beta$-(1,3)(1,4)-glucanase) activity was determined spectrophotomętrically using $1.0 \%$ barley $\beta$-glucan (Biocon Biochemicals Ltd., Ireland) in McIlvaine's buffer at $\mathrm{pH}$ 5.0 as substrate. $0.2 \mathrm{ml}$ of suitable enzyme dilution in deionized water was incubated with $2.0 \mathrm{ml}$ of substrate solution at $40^{\circ} \mathrm{C}$ for 30 minutes. Reducing sugars were assayed by addition of $3.0 \mathrm{ml}$ 3,5-dinitrosalisylic acid (DNS) reagent (SUMNER and SOMERS 1949), boiling for 5 minutes, cooling and measuring absorbance at $540 \mathrm{~nm}$. One $\beta$-glucanase unit is the amount of enzyme that liberates $1 \mu \mathrm{mol}$ of reducing sugars (expressed as glucose equivalents) in one minute under the conditions described.

Xylanase (EC 3.2.1.8; endo-(6-(1,4)-xylanase) activity (modified from POUTANEN et al. 1986) was determined using 1\% oat spelt xylan (Sigma X0376) in McIlvaine's buffer at pH 5.0 as substrate. $0.2 \mathrm{ml}$ of suitable enzyme dilution was incubated with $2.0 \mathrm{ml}$ of substrate solution at $40^{\circ} \mathrm{C}$ for 30 minutes. The reducing sugars were assayed as described above. One xylanase unit is the amount of enzyme that liberates $1 \mu \mathrm{mol}$ of reducing sugars (expressed as xylose equivalents) in one minute under the conditions described.

$\beta$-xylosidase (EC 3.2.1.37; 1,4- $\beta$-D-xylan xylohydrolase) activity was determined (modified from DELEYN et al. 1978) using 2 mmol/l p-nitrophenyl$\beta$-D-xylopyranoside in McIlvaine's buffer at $\mathrm{pH}$ 5.0 as substrate. $0.2 \mathrm{ml}$ of suitable enzyme dilution in deionized water was incubated with $2.0 \mathrm{ml}$ substrate solution in $40^{\circ} \mathrm{C}$ at $\mathrm{pH} 5.0$ for 30 minutes. After adding $1.0 \mathrm{ml}$ of $\mathrm{Na}_{2} \mathrm{CO}_{3}$, absorbance was measured at $400 \mathrm{~nm}$. One $\beta$-xylosidase unit is the amount of enzyme that liberates one $\mu \mathrm{mol}$ of p-nitrophenol in one minute under the conditions described.

Each enzyme activity measurement was carried out in duplicates or triplicates unless otherwise stated. Values are expressed as means with standard deviations of each sample. Means were separated where appropriate by paired t-test.

\section{Results and discussion}

\section{pH stability}

Incubation in $\mathrm{pH} 2.5$ did not reduce the xylanase activity of Multifect $\mathrm{K}$, whereas the $\beta$-xylosidase activity was reduced to $57 \%(\mathrm{P}<0.05)$ of the initial value (Table 1). Subsequent incubation at $\mathrm{pH} 7$ only marginally reduced xylanase activity and had no effect on $\beta$-xylosidase. Addition of wheat gluten markedly increased the recovery of $\beta$-xylosidase after incubation in $\mathrm{pH} 2.5(\mathrm{P}<0.05)$ and $\mathrm{pH} 7$ $(\mathrm{P}<0.10)$, resulting in full recovery of this activity. Maintaining $\mathrm{pH}$ at 2.5 by addition of citric acid 
Table 1. Initial and residual xylanase and $\beta$-xylosidase activities of Multifect $\mathrm{K}$, measured at $\mathrm{pH} 5$, after incubation at acidic and neutral $\mathrm{pH}$ with and without pepsin and pancreatin, and with $(+)$ and without $(-)$ gluten (means \pm sd).

\begin{tabular}{|c|c|c|c|c|c|c|c|c|c|}
\hline \multirow{3}{*}{ Gluten } & & \multicolumn{4}{|c|}{ Xylanase } & \multicolumn{4}{|c|}{$\beta$-xylosidase } \\
\hline & & \multirow[b]{2}{*}{$\mathrm{U} / \mathrm{g}$} & \multirow[b]{2}{*}{$\%$} & \multicolumn{2}{|l|}{+} & \multicolumn{2}{|c|}{-} & \multicolumn{2}{|c|}{+} \\
\hline & & & & $\mathrm{U} / \mathrm{g}$ & $\%$ & $\mathrm{U} / \mathrm{g}$ & $\%$ & $\mathrm{U} / \mathrm{g}$ & $\%$ \\
\hline Initial & pH 5 & $4510 \pm 80$ & 100 & $4970 \pm 27$ & 100 & $44 \pm 3$ & 100 & $30 \pm 2$ & 100 \\
\hline \multirow[t]{2}{*}{ Residual } & pH 2.5 & $4440^{\circ}$ & 98 & $4780^{\circ}$ & 96 & $25^{y} \pm 1$ & 57 & $30^{\mathrm{a}} \pm 1$ & 100 \\
\hline & pH 7 & $4070 \pm 235$ & 90 & $4720^{\circ}$ & 95 & $25^{y} \pm 1$ & 57 & $30^{b} \pm 2$ & 100 \\
\hline Pepsin & pH 2.5 & $4270^{\circ}$ & 95 & $4520^{\circ}$ & 91 & $30^{y} \pm 2$ & 68 & $18^{y} \pm 0$ & 60 \\
\hline Pancreatin & pH 7 & $2590^{x} \pm 4$ & 57 & $3400^{\circ}$ & 68 & $25 \pm 5$ & 57 & $29 \pm 2$ & 97 \\
\hline
\end{tabular}

result of one measurement

* differ from initial value $(\mathrm{P}<0.05)$

$y$ differ from initial value $(\mathrm{P}<0.10)$

a differ from corresponding control $(+)(\mathrm{P}<0.05)$

${ }^{b}$ differ from corresponding control $(+)(\mathrm{P}<0.10)$

Table 2. Initial and residual $\beta$-glucanase and xylanase activities of Avizyme SX, measured at pH 5, after incubation at acidic and neutral $\mathrm{pH}$ with and without pepsin and pancreatin, and with (+) and without (-) $\mathrm{pH}$ adjustment (means \pm sd).

\begin{tabular}{|c|c|c|c|c|c|c|c|c|c|}
\hline \multirow{3}{*}{\multicolumn{2}{|c|}{ pH adjustment ${ }^{\prime}$}} & \multicolumn{4}{|c|}{$\beta$-glucanase } & \multicolumn{4}{|c|}{ Xylanase } \\
\hline & & \multicolumn{2}{|l|}{+} & \multicolumn{2}{|l|}{-} & \multicolumn{2}{|l|}{+} & \multicolumn{2}{|l|}{-} \\
\hline & & $\mathrm{U} / \mathrm{g}$ & $\%$ & $\mathrm{U} / \mathrm{g}$ & $\%$ & $\mathrm{U} / \mathrm{g}$ & $\%$ & $\mathrm{U} / \mathrm{g}$ & $\%$ \\
\hline Initial & $\mathrm{pH} 5$ & $870 \pm 5$ & 100 & $850 \pm 15$ & 100 & $460 \pm 16$ & 100 & $467 \pm 38$ & 100 \\
\hline \multirow[t]{2}{*}{ Residual } & pH $2.5 / 3.2$ & $370^{x} \pm 6$ & 43 & $830^{a} \pm 28$ & 96 & $340^{y} \pm 6$ & 75 & $510^{b} \pm 20$ & 109 \\
\hline & $\mathrm{pH} 7$ & $390^{x} \pm 8$ & 45 & $790^{a} \pm 28$ & 92 & $260^{x} \pm 2$ & 57 & $422^{a} \pm 6$ & 90 \\
\hline Pepsin & pH $2.5 / 3.2$ & $370^{x} \pm 17$ & 42 & $850^{a} \pm 13$ & 100 & $360^{y} \pm 3$ & 78 & $510^{b} \pm 18$ & 110 \\
\hline Pancreatin & $\mathrm{pH} 7$ & $310^{x} \pm 9$ & 36 & $760^{a} \pm 30$ & 89 & $260^{x z} \pm 12$ & 56 & $470^{b} \pm 21$ & 100 \\
\hline
\end{tabular}

1 (+) means pH kept constant at 2.5 by addition of either $2 \mathrm{M}$ citric acid (pH stability) or $6 \mathrm{~N} \mathrm{HCl}$ (pepsin stability), (-) means no acid addition during the incubation with $\mathrm{pH}$ rising to 3.2 .

${ }^{x}$ differ from initial value $(\mathrm{P}<0.05)$

y differ from initial value $(\mathrm{P}<0.10)$

${ }^{2}$ differ from pH $2.5(\mathrm{P}<0.05)$

a differ from corresponding control $(+)(\mathrm{P}<0.05)$

${ }^{b}$ differ from corresponding control $(+)(\mathrm{P}<0.10)$

resulted in $43 \%(\mathrm{P}<0.05)$ recovery of $\beta$-glucanase and $75 \%$ recovery of xylanase $(\mathrm{P}<0.10)$ in Avizyme $\mathrm{SX}^{\circledR}$ (Table 2). Subsequent incubation at pH 7 had no effect on the $\beta$-glucanase activity, whereas xylanase was reduced to $57 \%(\mathrm{P}<0.05)$ of the initial activity. When $\mathrm{pH}$ was not adjusted, leading to a 0.7 unit increase in $\mathrm{pH}, \boldsymbol{\beta}$-glucanase recovery after the first incubation (pepsin in $\mathrm{pH} 3.2$ ) was $96 \%(\mathrm{P}>0.05)$ and after the second incubation (pan- creatin in $\mathrm{pH} 7$ 7) $92 \%$. The corresponding recoveries for xylanase were 109 and $90 \%$. This difference was not significant $(\mathrm{P}>0.10)$.

From these results it appears that low $\mathrm{pH}$ per se did not cause any dramatic reductions in enzyme activity and that addition of wheat gluten may reduce the degree of inactivation of more sensitive enzymes i.e. in this case $\beta$-xylosidase. Whether this effect is due to an increased dry matter content of 
the system or e.g. binding between the gluten and the enzyme is not known. Interestingly, with wheat being the carrier material of Avizyme SX ${ }^{\circledR}$ thus providing the system with gluten, xylanase recoveries were lower with and higher without $\mathrm{pH}$ adjustment than when gluten was added to Multifect $\mathrm{K}$.

\section{Pepsin and pancreatin stability}

Xylanase and $\beta$-xylosidase recoveries after incubation of Multifect $\mathrm{K}$ with pepsin was 95 and $68 \%$ without and 91 and $60 \%$ with added gluten, respectively (Table 1). These effects were not significant $(\mathrm{P}>0.10)$, with the exception being $\beta$-xylosidase when incubated at $\mathrm{pH} 2.5$ with added gluten $(\mathrm{P}<0.10)$. After the subsequent incubation in pancreatin the corresponding recoveries were 57 and $57 \%$ and 68 and $97 \%$, respectively ( $P>0.10)$. Thus $\beta$-xylosidase seemed to be more sensitive to pepsin than xylanase. Incubation with pancreatin tended to further reduce enzyme activity, except the activity of $\beta$-xylosidase when gluten was added.

$\beta$-glucanase activity of Avizyme $S X^{\circledR}$ decreased to $42 \%(\mathrm{P}<0.05)$ of the initial value after incubation in pepsin with $\mathrm{pH}$ kept at 2.5 by addition of hydrochloric acid and was further reduced to $36 \%$ after incubation in pancreatin (Table 2). With no $\mathrm{pH}$ adjustment, the $\beta$-glucanase recoveries after pepsin treatment was $100 \%$ and after incubation with pancreatin $89 \%(\mathrm{P}>0.10)$. These recoveries were significantly higher than when $\mathrm{pH}$ was kept at 2.5 $(\mathrm{P}<0.05)$. Xylanase recoveries after pepsin and pancreatin incubations with $\mathrm{pH}$ adjustment were 78 and $56 \%$ of the initial activity $(\mathrm{P}<0.10)$, respectively. Without $\mathrm{pH}$ adjustment xylanase was fully recovered. These recoveries were significantly higher than with $\mathrm{pH}$ adjustment $(\mathrm{P}<0.10)$.

Addition of wheat gluten to the enzyme/substrate systems tended to increase the final enzyme recoveries but this effect was not observed at $\mathrm{pH} 2.5$, except for $\beta$-xylosidase after incubation at $\mathrm{pH} 2.5$ without pepsin. DE CORDT et al. (1992) found that both polyols and carbohydrates increased the temperature stability of bacterial $\alpha$-amylase. The mechanisms involved were not specifically elucidated but "preferential protein hydration", changes in the chemical potential of the proteins, changes in the solvent dielectric constant, changes in the water activity of the solvent system, degree of water organisation were suggested. It is possible that wheat gluten used in this present experiment exerted one of these effects leading to increased $\mathrm{pH}$ and proteolytic stability. Interestingly, the buffering capacity of the feed enzyme product, probably due to the cereal carrier material, had a clear stabilising effect on the enzyme activities measured. Feed arriving in the stomach of pigs exert similar $\mathrm{pH}$ buffering effects (KIDDER and MANNERS 1978) and it can therefore be assumed that the feed acts as a potent stabilizer in the animal.

Results from a number of experiments with pigs and poultry would suggest that sufficient activity of supplementary enzymes survive the potential hazards of the GI-tract to improve animal performance (CHESSON 1987, DIERICK 1990). Enzyme recovery measurements in different segments of the GI-tract would be needed to exactly establish the rate and extent of feed enzyme inactivation in vivo.

Acknowledgements. The authors want to thank Ms Päivi Rantalaiho and Mrs Jaana Oksanen at the Cultor Ltd. Technology Centre for technical assistance during these investigations. This work was funded by Finnfeeds International Ltd., Marlborough, Wiltshire, U.K.

\section{References}

Chesson, A. 1987. Supplementary enzymes to improve the utilisation of pig and poultry diets. In: Haresign W. \& Cole D.J.A. (eds.). Recent Advances in Animal Nutrition 1987. Butterworths, London. p. 71-89.

DiERICK, N.A. 1990. Biotechnology aids to improve feed and feed digestion: enzymes and fermentation. Arch. Anim.
Nutr. Berlin 39: 241-261.

De Cordt, S., Saravia, J., Hendrickx, M., Maesmans, G. \& Tовваск, P. 1992. Changing the thermostability of Bacillus licheniformis $\alpha$-amylase. Proc. Int. Symp. on 'Stability and stabilisation of enzymes'. Maastricht, The Netherlands. Poster. 
Deleyn, F., Claeyssens M., van Beeumen, J. \& De Bruyne, C.K. 1978. Purification and properties of $\beta$-xylosidase from Penicillium wortmanni. Can. J. Biochem. 56: 4350.

Godfrey, T. \& Reichelt, J. 1983. Industrial enzymology. 582 p. Stockton Press, New York, NY.

KidDER, D.E. \& ManNERS, M.J. 1978. Digestion in the pig. 204 p. Scientechnica, Bristol, U.K.

PACE, C.N. 1990. Measuring and increasing protein stability. Tibtech 8: 93-98.

Poutanen, K., Puls, J. \& Linko, M. 1986. The hydrolysis of steamed birchwood hemicellulose by enzymes produced by Trichoderma reesei and Aspergillus awamori. Appl. Microbiol. Biotechnol. 28: 419-424.

Simons, G. \& Georgatsos, J.G. 1990. Immobilisation of barley $\beta$-glucosidase on solid supports - yields and properties. Appl. Microbiol. Biotechnol. 33: 51-53.

St. Cl.air, N.L. \& NAviA, M.A. 1992. Crosslinked enzyme crystals as robust biocatalysts. J. Amer. Chem. Soc. 114: 7314-7316.

SUMNER, J.B. \& SOMERS, G.F. 1949. Dinitrosalicylic acid for glucose. In: Laboratory experiments in biological chemistry, $2^{\text {nd }}$ ed., Academic Press, New York. p. 3839.

Manuscript received February 1993

Johan Inborr

Finnfeeds International Ltd.

Market House, High Street

Marlborough, Wiltshire SN8 1AA

United Kingdom

Present address:

Finnsugar Gmbh

Raboisen 58

D-20095 Hamburg 1, Germany

Anne Grönlund

Cultor Ltd.,Technology Centre

FIN-02640 Kantvik, Finland 


\title{
SELOSTUS
}

\section{Rehuentsyymien stabiilisuus fysiologisissa olosuhteissa in vitro -menetelmin mitattuna}

\author{
JOHAN INBORR ja ANNE GRÖNLUND \\ Finnfeeds International Ltd. ja Cultor Ltd.
}

Kahden entsyymipreparaatin, Trichoderma longibrachiatumin tuottaman ksylanaasin (Multifekt $\mathrm{K}$ ) ja rehuentsyymituotteen (Avizyme $\mathrm{SX}^{8}$ ), stabiilisuutta tutkittiin in vitro -menetelmin sellaisissa olosuhteissa, jotka vallitsevat yksimahaisten ruoansulatuskanavan yläosissa. Ksylanaasipreparaatista tarkasteltiin ksylanaasi- ja $\beta$-ksylosidaasiaktiivisuuksien-, sekä Avizyme $S^{\circledast}$ :stä $\beta$-glukanaasi- ja ksylanaasiaktiivisuuksien stabiilisuutta. Aluksi tutkittiin entsyymiaktiivisuuksien stabiilisuutta eri pH:ssa (2,5 ja 7$)$ ja sen jälkeen pepsiinin ja pankreatiinin vaikutusta entsyymiaktiivisuuksiin. Tutkimuksessa selvitettiin myös vehnägluteenin entsyymiaktiivisuuksia stabiloivaa vaikutusta.

Inkubointi $\mathrm{pH}$ 2,5:ssä ja sen jälkeen $\mathrm{pH} 7$ :ssä ei vaikuttanut merkitsevästi Multifekt K:n ksylanaasiaktiivisuuteen. Sen sijaan $\beta$-ksylosidaasiaktiivisuus aleni 57 \%:iin alkutasosta $(\mathrm{P}<0.05)$ ilman vehnägluteenilisäystä. Vehnägluteenilisäyksellä $\beta$-ksylosidaasiaktiivisuus pysyi alkutasolla. Avizyme $\mathrm{SX}^{\circledast}$ :n $\beta$-glukanaasi- ja ksylanaasiaktiivisuus aleni merkitsevästi kun sitruunahappoa lisättiin inkuboinneissa. Ilman happolisäystä enstyymiaktiivsuudet pysyivät alkutasoilla.
Inkubointi pepsiinillä ja pankreatiinilla alensi merkitsevästi $(\mathrm{P}<0.05)$ Multifekt K:n ksylanaasiaktiivisuutta. $\beta$-ksylosidaasi aleni $68 \%$ :iin pepsiini-inkuboinnin jälkeen $(\mathrm{P}<0.10)$ ja $57 \%$ :iin pankreatiini-inkuboinnin jälkeen $(\mathrm{P}>0.10)$. Pepsiiniinkuboinnissa vehnägluteenilisäys ei parantanut stabiilisuutta, mutta pankreatiini-inkuboinnissa vehnägluteenin lisäys nosti $\beta$-ksylosidaasiaktiivisuuden $97 \%$ :iin alkutasosta. Avizyme $\mathrm{SX}^{\infty}$ :n pepsiini- ja pankreatiini-inkuboinnit ja happolisäys alensivat merkitsevästi $(\mathrm{P}<0.05) \quad \beta$-glukanaasi- ja ksylanaasiaktiivisuutta. Ilman happolisäystä aktiivisuudet pysyivät alkuperäisillä tasoilla.

Tulokset osoittavat, että entsyymien osittainen inaktivoituminen voi tapahtua matalassa $\mathrm{pH}$ :ssa ja proteolyyttisissä olosuhteissa. Avizyme $\mathrm{SX}^{\circledR}$ :llä ja vehnägluteenilisäyksellä saatujen tulosten perusteella on kuitenkin odotettavaa, että rehun mahalaukun sisältöä puskuroiva vaikutus suojaa rehuun lisättyjä entsyymejä inaktivoitumiselta suhteellisen tehokkaasti. Rehuun lisättyjen entsyymien todellisen inaktivoitumisasteen määrittämiseksi joudutaan kuitenkin suorittamaan vastaavat mittaukset kohde-eläimiä käyttämạallä. 


\section{Nutritional implications of feeding enzyme-treated wheat bran}

$$
\text { to pigs }
$$

1. Recovery of added enzyme activities in the stomach and terminal ileum

BY JOHAN INBORR ${ }^{1,2^{*}}$, JAN VAN DER MEULEN ${ }^{1}$ AND JARI PUHAKKA ${ }^{3}$

${ }^{1}$ DLO Research Institute for Livestock Feeding and Nutrition (IVVO-DLO),

P.O. Box 160, NL-8200 AD Lelystad, The Netherlands

${ }^{2}$ Finnfeeds Intemational Ltd., Market House, High Street, Marlborough,

Wiltshire SN8 1AA, United Kingdom

${ }^{3}$ Cultor Ltd. Technology Centre, SF-02460 Kantvik, Finland

'Present address: Svenska Foder Ab, Kinnegatan 23, Box 673, S-53116 Lidköping, Sweden 
Five crossbred barrows of approximately $31 \mathrm{~kg}$ live weight were fitted with a stomach and a post valve T-caecum cannula and fed five experimental diets for five two-week periods in a 5 x 5 Latin Square design. The diets contained wheat bran as the only source of non-starch polysaccharides (NSP). The wheat bran of the control diet (C) was incubated with a water:acetic acid mixture at $39^{\circ} \mathrm{C}$ and $\mathrm{pH} 5.0$ for 3.5 hours. For treatments Cel-I and Xyl-I the wheat bran was incubated in the same conditions with either an added crude cellulase or a xylanase preparation. Immediately before feeding, wheat bran treated in the same way as $C$ was supplemented with either the cellulase or xylanase preparation to give treatments $\mathrm{Cel}-\mathrm{A}$ and $\mathrm{Xyl}-\mathrm{A}$, respectively. The pigs were fed twice daily and gastric and ileal digesta collected on separate days between days 7 and 14in 2-hour intervals for 12 hours. Samples collected between 0 and 6 hours after feeding were analysed for xylanase and B-glucanase activities using either standard or modified (according to sample $\mathrm{pH}$ and physiological temperature) assay methods to estimate the degree of survivability. Immediately after feeding both the xylanase and $\beta$ glucanase activities in the stomach of pigs fed the Cel-diets were significantly $(P<0.05)$ higher than the controls. At 4 hours after feeding only Cel-A had higher B-glucanase activity $(P<0.05)$ than the control pigs. In the gastric samples the modified method gave significantly $(P=0.001)$ lower xylanase values than the standard method. Between 2 and 6 hours after feeding the xylanase activity of ileal samples of pigs fed the xylanasetreated wheat bran were significantly $(P<0.05)$ higher than the controls, whereas $\beta$ glucanase activity in samples obtained from the pigs fed the cellulase-treated diets were higher than the controls between 4 and 6 hours after feeding. In the ileal samples, the modified method gave significantly higher xylanase and lower $\beta$-glucanase activity values than the standard method $(P=0.001)$. It is concluded that xylanase and $\beta$-glucanase activities can be measured in digesta samples with the methods employed and that the added enzymes were largely inactivated between the feedings. Measuring digesta enzyme activities in conditions similar to the ones in the GI-tract may give a more reliable picture of the actual activity of added enzymes.

INDEXING KEY WORDS: wheat bran, enzyme treatment, xylanase, cellulase, $\beta$ glucanase, assay method, enzyme recovery, gastric and ileal cannula, dietary fibre, NSP. 
Dietary fibre (DF) is composed of a very heterogenous mixture of substances, mainly associated with plant cell walls, which may be defined as non-starch polysaccharides (NSP) and lignin. Due to its complex physical and chemical characteristics, DF influences many processes and reactions in the digestive system of the pig, thus influencing the utilisation of feed (Low, 1985).

The main DF components of wheat and wheat by-products are the so called pentosans or arabinoxylans (Annison et al., 1992). In wheat bran, the content of arabinoxylans (the sum of the pentose sugars arabinose and xylose) can vary. Graham et al. (1986a) found 20.6 per cent (48 per cent of DF) and Bach Knudsen \& Hansen (1991) 26.2 per cent (52 per cent of DF) arabinoxylans on a dry matter basis in wheat bran. Thus depending on the origin and milling process, the DF content and chemical composition of wheat bran may vary considerably.

Since the pig does not produce enzymes capable of degrading dietary fibre components it has to rely on the microbial fermentation in the gastrointestinal tract to extract energy from high fibre feedstuffs such as wheat bran. Treating wheat bran with cell wall degrading enzymes before feeding or supplementation of the feeds with such enzymes may increase its digestibility and hence utilisation. Neudoerffer and Smith (1969) reported increased protein digestibility and performance of rats after cellulase and subtilisin treatment of wheat bran. In an experiment with broiler chickens, supplementation of a diet containing 20 per cent wheatbran with a Trichoderma viride cellulase significantly increased the digestibility of cell wall components and tended to improve feed utilisation (Nahm and Carlson, 1985). In a study by McClean and McCracken (1992) enzyme supplementation of a wheat feed-based diet did not influence ileal or faecal dry matter, crude protein and energy digestibility, whereas Schutte et al. (1990) reported increased feacal digestibility of crude fibre, protein and fat due to supplementation of wheat bran with a commercial cellulolytic enzyme preparation. Thus there appear to be an opportunity for cell wall degrading enzymes to improve the nutritional value of wheat bran also for pigs.

Enzyme activity assays are usually carried out according to standardised procedures. The conditions of an assay ( $\mathrm{pH}$, temperature, substratre concentration etc.) are in general reflecting the conditions of the application in which the enzyme is used or determined by the optimum conditions for the enzyme itself. This can limit the applicability of the enzyme assay or possibly give a false picture of how an enzyme will perform in other applications. 
Modification of current standard assay methods may be necessary in order to estimate the actual activity in different sections of the GI-tract and possibly explain the response in nutrient digestibility and performance of the animals due to enzyme supplementation.

The aims of this study were to investigate the nutritional implications of treating wheat bran with fibre degrading enzymes on the digestibility of nutrients along the digestive tract and other physiological parameters including $\mathrm{pH}$, osmolality and VFA concentration. In addition, recoveries of two dietary enzyme activities in the stomach and ileum were measured. Two enzyme preparations were employed either for pre-treatment of the wheat bran or to be added to the diets immediately prior to feeding.

In this first paper the results of the enzyme recovery measurements, using two (either a standard or a modified) enzyme assays, are presented.

\section{MATERIALS AND METHODS}

Animals and experimental design

Five crossbred (Dutch Landrace x Yorkshire x Finnish Landrace) barrows of 30.7 $2.0 \mathrm{~kg}$ body weight were fitted with a stomach cannula (Mroz \& van der Meulen, in preparation) and a post valve T-caecum (PVTC) cannula (van Leeuwen et al., 1988) under inhalation anaesthesia. After a recovery period of four weeks, the pigs were housed individually in standard metabolism cages at an average room temperature of $18^{\circ} \mathrm{C}$. Each pig was randomly assigned to one of five dietary treatments consisting of semisynthetic diets fed in five consecutive periods in a balanced 5 x 5 Latin Square design.

\section{Diets and diet preparation}

All diets had the same composition with wheat bran as the only source of NSP (Table 1). The wheat bran was incubated with water at a ratio of $6.25: 1(\mathrm{v} / \mathrm{w})$ and acetic acid (96\%) was added $\left(0.02: 1(\mathrm{v} / \mathrm{w})\right.$ to give $\mathrm{pH} 5.0$. The mixture was incubated at $39^{\circ} \mathrm{C}$ for 3.5 hours to give diet $\mathrm{C}$ (control). For the preparation of treatments Cel-I and Xyl-I, wheat bran was incubated in the same conditions as the control with either an added cellulase $(10 \mathrm{~g} / \mathrm{kg}$; Cel-I) or a xylanase preparation $(0.1 \mathrm{~g} / \mathrm{kg} ; \mathrm{Xyl}-\mathrm{I})$. After the incubations, the wheat bran and the incubation buffer were divided into portions of equal size and stored in plastic boxes at 
$-20^{\circ} \mathrm{C}$. Incubations were carried out weekly during the course of the experiment. Before feeding the frozen portions were thawed at room temperature and thoroughly mixed with the balance of the experimental diets, resulting in a slurry with a water:feed ratio of $2.5: 1(\mathrm{v} / \mathrm{w})$. Immediately before feeding, $10 \mathrm{~g}$ of the cellulase and $0.1 \mathrm{~g}$ of the xylanase preparation per $\mathrm{kg}$ wheat bran were added to diet $\mathrm{C}$ to form treatments Cel-A and Xyl-A, respectively. All diets contained $2 \mathrm{~g} / \mathrm{kg}$ chromium-mordanted starch (Cr-starch) as an indigestible marker.

Table 1. Composition of the basal diet $(\mathrm{g} / \mathrm{kg})$

Ingredients

Wheat bran ${ }^{1}$

Maize starch

Casein

Limestone

Salt

DL-Methionine

Mineral/vitamin premix $^{2}$

Choline chloride

Cr-starch

Co-EDTA
400.00

493.05

82.00

14.00

2.50

0.80

1.40

0.25

2.00

4.00

${ }^{1}$ incubated in buffer with or without enzymes

${ }^{2}$ provided the following ingredients ( $\mathrm{mg} / \mathrm{kg}$ diet): retinol 3.9, cholecalciferol 0.04, DL- $\alpha$ tocopherol 8, riboflavin 4, cyanocobalamin 0.02, nicotinic acid 20, pantothenic acid 7.84, antioxidant 125, $\mathrm{FeSO}_{4} \star 7 \mathrm{H}_{2} \mathrm{O} 430, \mathrm{MnO} 50, \mathrm{ZnSO}_{4} \star \mathrm{H}_{2} \mathrm{O} 155, \mathrm{KI} 2, \mathrm{Na}_{2} \mathrm{SeO}_{3} \star 5 \mathrm{H}_{2} \mathrm{O} 7$ and carrier 587.2. 
Enzymes

The enzymes used in the experiment were a Trichoderma longibrachiatum cellulase and a Trichoderma viride xylanase preparation (Genencor International Ltd., Helsinki, Finland). Both products were crude enzyme preparations containing cellulolytic, hemicellulolytic and xylanolytic activities (Table 2). The xylanase preparation contained approximately 100 times more xylanase (oat spelt xylan, $\mathrm{pH}$ 5.3) and slightly less $\beta$-glucanase (barley $\beta$-glucan, $\mathrm{pH}$ $5.0)$ activity than the cellulase preparation. Since the arabinoxylans are the main NSP fraction of wheat bran, and hence considered as the main target substrate, the two enzyme preparations were added to provide equal amount of xylanase activity based on the activities measured in the crude preparations. This resulted in a many-fold higher $\beta$-glucanase activity in the diets supplemented with the cellulase compared with those supplemented with the xylanase preparation.

Table 2. Main activities of the crude enzyme preparations measured by standard methods ${ }^{1}$ (units/g)

Substrate

$\mathrm{pH}$

Cellulase

Xylanase

T. longibrachiatum

T. viride

Barley $\beta$-glucan

5.0

10390

8440

Oat spelt xylan

5.3

1445

142050

Carboxymethylcellulose

5.0

7370

5045

Filter paper

5.0

355

220

${ }^{1}$ measured at the Cultor Ltd. Technology Centre, Kantvik, Finland 


\section{Feeding and collection procedures}

The pigs were fed twice daily (at 08.30 and 20.30 hours) at 2.3 times maintenance requirement $\left(=418 \mathrm{~kJ} \mathrm{ME} / \mathrm{BW}^{0.75}\right)$ and had no access to water between the feedings. The pigs were weighed weekly.

Each treatment period lasted 14 days and the animals were switched directly form one diet to the next at the end of each period. Ileal digesta was quantitatively collected on the 4th and 11 th day in two-hour intervals for 12 hours, beginning at $08.30 \mathrm{~h}$. The digesta was collected in polyethylene bags attached to the cannula and kept on dry ice. Each two-hourly sample was weighed and immediately after $\mathrm{pH}$ had been measured, frozen and stored at $-20^{\circ} \mathrm{C}$. On days 6 and 13 faeces and urine were collected quantitatively for 24 hours, then frozen and stored at $-20^{\circ} \mathrm{C}$.

Gastric digesta was collected once daily on days 7, 8, 9, 10 and 14 after the morning feeding. Collection times were immediately after the pigs had finished their meals $(0.5 \mathrm{~h})$, 2, 4, 6 and 8 hours after feeding. The stomach was evacuated in a polyethylene tube attached to the cannula. The digesta sample was weighed, sampled and the remainder returned to the pig. Thereafter, $\mathrm{pH}$ was measured and the sample was frozen and stored at $-20^{\circ} \mathrm{C}$.

\section{Chemical and enzyme activity analysis}

Dry matter of the stomach and ileal digesta samples was determined after freeze drying according to the procedure of the Netherlands Normalization Institute (NEN 3332, 1974).

In addition to the wheat bran and diets, digesta samples taken from the stomach 0,2 and 4 hours and ileum from collections between 0-2, 2-4 and 4-6 hours after feeding were analysed for xylanase and $\beta$-glucanase activities. After thawing, samples of the incubated wheat brans, stomach and ileal digesta samples were centrifuged $(\mathrm{g} \bullet 13700)$ for 30 minutes at room temperature. The supernatants were retained and kept frozen until used for the enzyme activity measurements.

Xylanase (endo- $\beta$ - $(\mathbf{1 , 4})$-xylanase; EC 3.2.1.8) activity was determined by incubating $1 \mathrm{ml}$ substrate solution (1\% (w/v) oat-spelt xylan (Fluka 95590) in 0.05 M sodium acetate buffer at $\mathrm{pH} 5.3$ ) with $1 \mathrm{ml}$ supernatant diluted to suitable concentration at $50^{\circ} \mathrm{C}$ for 30 minutes. 
The reaction was terminated and the amount of reducing sugars released determined (Sumner \& Somers, 1949) by adding $3 \mathrm{ml} \mathrm{3,5-dinitrosalicylic} \mathrm{acid} \mathrm{(DNS)} \mathrm{reagent,} \mathrm{boiling} \mathrm{for} 5$ minutes and measuring the absorbance at $540 \mathrm{~nm}$ after cooling. The measured absorbance was subtracted with that of a blank sample (inactivated enzyme and DNS added to the supernatant) to estimate the amount of reducing sugars liberated due to enzyme activity. One xylanase unit is defined as the amount of enzyme needed to release $1 \mu \mathrm{mol}$ of reducing sugars (expressed as xylose) in one minute under the assay conditions specified.

$\beta$-glucanase (endo- $\beta$-(1,3)(1,4)-glucanase; EC 3.2.1.6) activity was determined spectrophotometrically. $1 \mathrm{ml}$ of substrate solution $(1 \% \mathrm{w} / \mathrm{w})$ barley $\beta$-glucan (Biocon Biochemicals Ltd., Co Cork, Ireland) in distilled water) was incubated with $1 \mathrm{ml}$ supernatant (diluted with $0.1 \mathrm{M}$ sodium acteate buffer at $\mathrm{pH} 5.0$ to suitable concentration) for 10 minutes at $40^{\circ} \mathrm{C}$. The reaction was terminated and the amount of reducing sugars released determined as described above in the xylanase assay. One $\beta$-glucanase unit is defined as the amount of enzyme required to release $1 \mu \mathrm{mol}$ of reducing sugars (expressed as glucose) in one minute under the assay conditions specified.

Assay method modification

Since $\mathrm{pH}$ and temperature in the GI-tract of the pig are different from the ones used in the above described standardised enzyme assays, it was decided to measure the enzyme activities of digesta samples also by 'modified' methods to give a better estimate of the actual enzyme activity in different parts of the GI-tract. Consequently, the assay temperature used in the modified methods was $39^{\circ} \mathrm{C}$, incubation time 60 minutes and assay pH (and substrate solution in the xylanase assay) was adjusted with McIlvaine's buffer to $\pm 0.1 \mathrm{pH}$ units of the measured sample pH.

\section{Calculations and statistical analysis}

The enzyme activities are expressed on a dry matter (DM) basis and were calculated using the following equation;

$\mathrm{U} / \mathrm{g} \mathrm{DM}=$

Units/ml supernatant * (g sample - g sample DM)

g sample DM 
assuming that $1 \mathrm{ml}$ supernatant weighs $1 \mathrm{~g}$. The survivability (residual activity) of added xylanase and $\beta$-glucanase activities were calculated based on the concentrations of the markers using the equation:

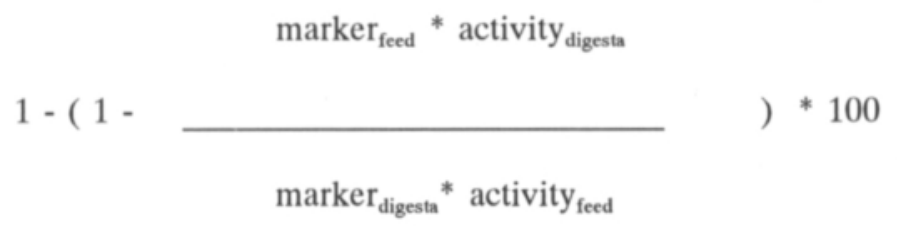

The data was subjected to analysis of variance according to the Latin square design, using the GENSTAT 5 statistical package (Payne et al., 1987).

\section{RESULTS}

Digesta $\mathrm{pH}$

$\mathrm{pH}$ of stomach contents decreased from an average value of 4.9 immediately after feeding to less than 3 after 4 hours (Table 3), whereas pH of the ileal chyme was fairly stable and decreased from 8.3 to 7.8 between 0 and 6 hours after feeding. There were no significant treatment effects on $\mathrm{pH}$ over this time period.

\section{Dietary and gastric enzyme activities}

Diets containing wheat bran treated with the xylanase preparation (Xyl-I) contained approximately $57 \%$ of the xylanase activity and $50 \%$ of the $\beta$-glucanase found in the wheat bran (Table 4). The corresponding values for the feeds containing the cellulase-treated wheat bran (Cel-I) were 49 and $48 \%$, respectively. 
Table 3. Average pH of stomach and ileal digesta samples

(means and SD).

\begin{tabular}{|c|c|c|c|c|c|}
\hline \multicolumn{3}{|c|}{ Stomach } & \multicolumn{3}{|c|}{ Ileum } \\
\hline Time, $\mathbf{h}^{1}$ & mean & SD & Time, $\mathrm{h}^{1}$ & mean & $\mathrm{SD}$ \\
\hline 0 & 4.86 & 0.19 & $0-2$ & 8.31 & 0.15 \\
\hline 2 & 4.29 & 0.26 & $2-4$ & 7.83 & 0.09 \\
\hline 4 & 2.94 & 0.19 & $4-6$ & 7.83 & 0.11 \\
\hline
\end{tabular}

${ }^{1}$ hours after feeding

Table 4. $\beta$-glucanase and xylanase activities (U/g DM) of the enzyme-treated wheat brans and corresponding experimental diets.

Treatment

Xylanase

$\beta$-glucanase

Wheat bran

Diet

Wheat bran

Diet

$\begin{array}{lcccc}\text { Control } & 5 & 3 & 10 & 5 \\ \text { Cel-I } & 41 & 20 & 146 & 70 \\ \text { Xyl-I } & 14 & 8 & 12 & 6\end{array}$


In pigs fed the cellulase-treated diets (Cel-I and Cel-A), xylanase activities of stomach digesta were significantly $(\mathrm{P}<0.05)$ higher than in the control pigs immediately after feeding when measured by the standard method (Table 5), whereas in pigs fed the xylanase-treated diets (Xyl-I and Xyl-A), xylanase activities were not significantly higher than in the controls. Similar observations were made with regard to values obtained using the modified methods. At 2 and 4 hours after feeding, stomach digesta samples of all pigs fed the enzyme-treated diets tended to contain more enzyme activity than the controls, although none of them significantly. Overall xylanase activity measured by the modified method was significantly $(\mathrm{P}=0.001)$ lower than when the standard method was employed (Table 9).

Table 5. Xylanase activity measured by standard and modified methods in units/g DM of gastric contents collected 0,2 and 4 hours after feeding.

Time, h C Cel-I $\quad$ Cel-A $\quad$ Xyl-I $\quad$ Xyl-A $\quad$ sed

$\begin{array}{lllllll}0 & 2.6^{\mathrm{a}} & 13.8^{\mathrm{bc}} & 16.4^{\mathrm{c}} & 9.0^{\mathrm{ab}} & 8.9^{\mathrm{ab}} & 3.0 \\ 2 & 1.6 & 7.6 & 10.1 & 3.8 & 5.6 & 4.2 \\ 4 & 0.6 & 0.9 & 2.5 & 1.5 & 2.4 & 1.1\end{array}$

\section{Contrast P-values}

Standard vs Modified

$\begin{array}{llllll}0 & 0.526 & 0.006 & <0.001 & 0.023 & 0.016 \\ 2 & 0.776 & 0.238 & 0.118 & 0.500 & 0.326 \\ 4 & 0.798 & 0.591 & 0.131 & 0.259 & 0.044\end{array}$

ab values within a row with no common superscripts are significantly different $(\mathrm{P}<0.05)$ 
$\beta$-glucanase activities of the stomach digesta samples taken 0 and 2 hours after feeding of pigs fed the cellulase-treated feeds $(\mathrm{Cel}-\mathrm{I}$ and $\mathrm{Cel}-\mathrm{A})$ were significantly $(\mathrm{P}<0.05)$ higher than the control and the xylanase-treated feeds with both assay methods (Table 6), At 2 and 4 hours after feeding, $\beta$-glucanase activity of Cel-A was significantly $(\mathrm{P}<0.05)$ higher than the control, Xyl-I and Xyl-A when measured by the standard method, and higher than the control, Xyl-I and Xyl-A 2 hours after feeding when measured by the modified method. Overall, values obtained with the modified method tended to be lower $(\mathrm{P}=0.071)$ than the ones obtained with the standard method (Table 9).

Table 6. $\beta$-glucanase activity measured by standard and modified methods in units/g DM of gastric contents collected 0,2 and 4 hours after feeding.

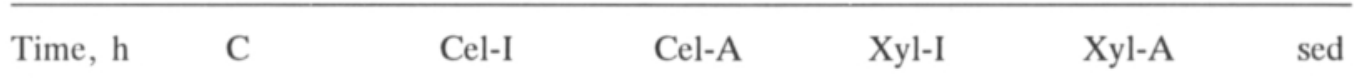

\begin{tabular}{rrrrrrr}
\multicolumn{5}{c}{ Standard } \\
0 & $2.9^{\mathrm{a}}$ & $65.8^{\mathrm{b}}$ & $63.1^{\mathrm{b}}$ & $3.3^{\mathrm{a}}$ & $4.6^{\mathrm{a}}$ & 11.8 \\
2 & $3.5^{\mathrm{a}}$ & $40.7^{\mathrm{b}}$ & $47.3^{\mathrm{b}}$ & $2.9^{\mathrm{a}}$ & $3.6^{\mathrm{a}}$ & 14.3 \\
4 & $1.9^{\mathrm{a}}$ & $6.5^{\mathrm{ab}}$ & $16.1^{\mathrm{b}}$ & $3.6^{\mathrm{a}}$ & $1.9^{\mathrm{a}}$ & 3.8
\end{tabular}

Contrast P-values

Standard vs Modified

$\begin{array}{llllll}0 & 0.830 & 0.186 & 0.228 & 0.812 & 0.735 \\ 2 & 0.802 & 0.575 & 0.466 & 0.837 & 0.804 \\ 4 & 0.364 & 0.229 & 0.093 & 0.588 & 0.568\end{array}$

${ }^{\text {ab }}$ values within a row with no common superscripts are significantly different $(\mathrm{P}<0.05)$ 
In the stomach, xylanase activity recovery (survivability) based on $\mathrm{Cr}$ decreased rapidly and was less than $10 \%$ of the initial activity in the diets supplemented with the cellulase and between 10-20 \% in the diets supplemented with the xylanase at 4 hours after feeding (Figure 1). The recovery of $\beta$-glucanase activity decreased to less than $15 \%$ at 4 hours after feeding (Figure 2).

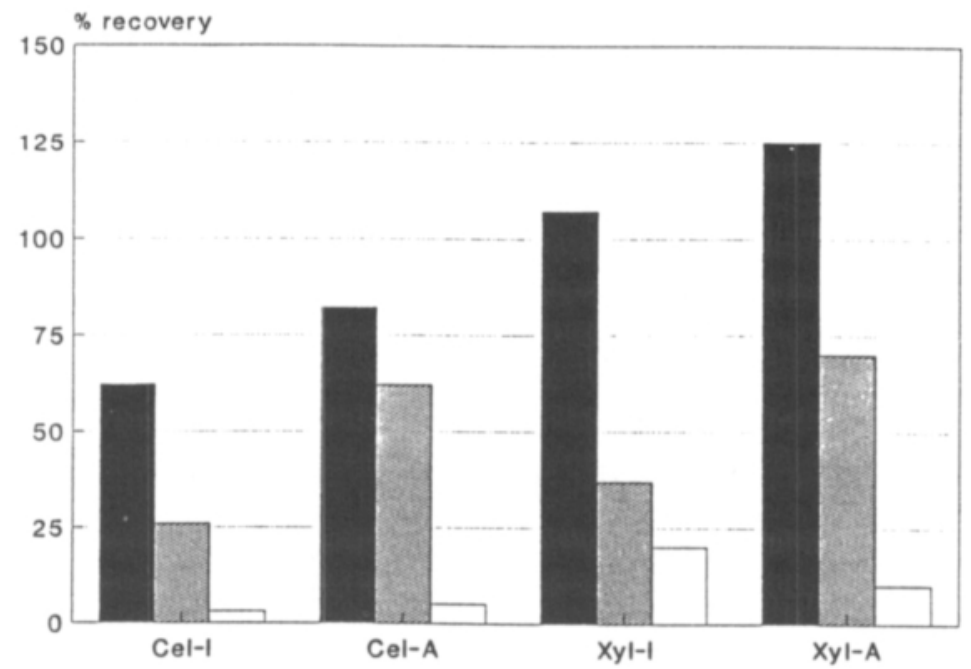

Figure 1. Recovery ( $\%$ of dietary concentration) of added xylanase activity in the stomach based on chromium at $0.5(\square), 2(\mathbb{Q})$ and $4(\square)$ hours after feeding.

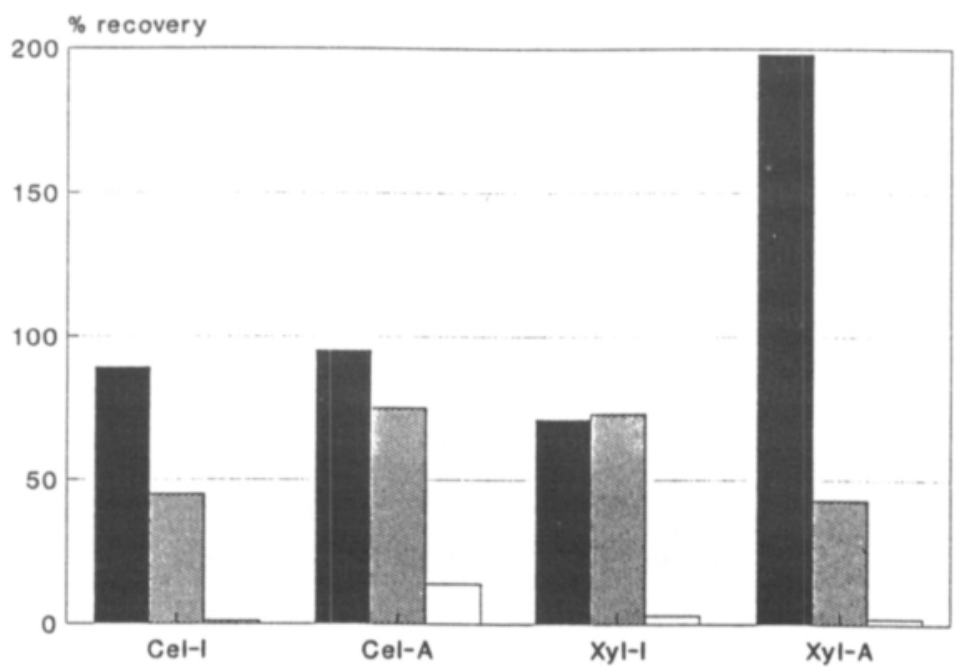

Figure 2. Recovery (\% of dietary concentration) of added $\beta$-glucanase activity in the stomach based on chromium at $0.5(\square), 2(\square)$ and $4(\square)$ hours after feeding. 
At the terminal ileum, both xylanase and $\beta$-glucanase activity of the control samples were relatively high and on the same level as that of the enzyme-treated diets in samples obtained during the first two hours after feeding (Table 7). Xyl-I and Xyl-A samples obtained between 2 and 6 hours after feeding contained approximately twice as much $(\mathrm{P}<0.05)$ xylanase activity as the control and the cellulase-treated diets when measured by the standard method. With the modified method, the only significant $(\mathrm{P}<0.05)$ differences obtained were between the xylanase-treated diets and Cel-I for samples taken between 2-4 hours, and between the control and the xylanase-treated feeds for samples taken between 4-6 hours after feeding.

Table 7. Xylanase activity measured by standard and modified methods in units/g DM of ileal contents collected during three two-hour periods after feeding.

\begin{tabular}{lllllll} 
Time, h & C & Cel-I & Cel-A & Xyl-I & Xyl-A & sed \\
\hline & & \multicolumn{5}{c}{ Standard } \\
$0-2$ & 20.5 & 20.1 & 15.3 & 23.2 & 24.6 & 5.2 \\
$2-4$ & $13.5^{\mathrm{a}}$ & $15.2^{\mathrm{a}}$ & $11.9^{\mathrm{a}}$ & $25.3^{\mathrm{b}}$ & $37.6^{\mathrm{c}}$ & 4.1 \\
$4-6$ & $14.1^{\mathrm{a}}$ & $14.9^{\mathrm{a}}$ & $15.0^{\mathrm{a}}$ & $26.5^{\mathrm{b}}$ & $28.1^{\mathrm{b}}$ & 3.2
\end{tabular}

\section{Modified}

$\begin{array}{lllllll}0-2 & 25.5 & 22.8 & 22.9 & 29.5 & 14.4 & 7.0 \\ 2-4 & 43.7^{\mathrm{ab}} & 30.8^{\mathrm{a}} & 36.5^{\mathrm{ab}} & 58.1^{\mathrm{bc}} & 67.3^{\mathrm{c}} & 8.2 \\ 4-6 & 26.6^{\mathrm{a}} & 30.0^{\mathrm{abc}} & 28.7^{\mathrm{ab}} & 38.1^{\mathrm{c}} & 34.5^{\mathrm{b}} & 2.9\end{array}$

Contrast P-values

Standard vs Modified

$\begin{array}{llllll}0-2 & 0.390 & 0.625 & 0.185 & 0.271 & 0.080 \\ 2-4 & 0.011 & 0.077 & 0.028 & 0.001 & 0.002 \\ 4-6 & 0.034 & 0.070 & 0.056 & 0.052 & 0.259\end{array}$

abc values within a row with no common superscripts are significantly different $(\mathrm{P}<0.05)$ 
In contrast to the stomach samples, overall xylanase activity values obtained using the modified method were higher than with the standard method (Table 9).

$\beta$-glucanase activity of the ileal samples were low with no significant difference between control and enzyme-treated samples except for the samples taken between 4 and 6 hours after feeding (Table 8).

Table 8. $\beta$-glucanase activity measured by standard and modified methods in units/g DM of ileal contents collected collected during three two-hour periods after feeding.

Time, h

C

Cel-I

Cel-A

Xyl-I

Xyl-A

sed

\section{Standard}

$\begin{array}{lllllll}0-2 & 17.2 & 10.0 & 12.0 & 16.1 & 14.7 & 3.4 \\ 2-4 & 17.1 & 26.3 & 18.2 & 14.1 & 13.1 & 4.7 \\ 4-6 & 10.3^{\mathrm{a}} & 18.6^{\mathrm{b}} & 17.5^{\mathrm{b}} & 15.4^{\mathrm{ab}} & 10.6^{\mathrm{a}} & 2.6\end{array}$

Modified

$\begin{array}{lllllll}0-2 & 4.1 & 1.3 & 2.3 & 3.8 & 1.7 & 1.1 \\ 2-4 & 4.5 & 4.7 & 4.1 & 7.1 & 3.6 & 2.2 \\ 4-6 & 2.9^{\mathrm{a}} & 4.7^{\mathrm{b}} & 5.1^{\mathrm{b}} & 5.0^{\mathrm{b}} & 3.2^{\mathrm{a}} & 0.6\end{array}$

Contrast P-values

Standard vs Modified

$\begin{array}{llllll}0-2 & <0.001 & 0.006 & 0.003 & <0.001 & <0.001 \\ 2-4 & 0.002 & <0.001 & <0.001 & 0.080 & 0.008 \\ 4-6 & 0.001 & <0.001 & <0.001 & 0.001 & 0.001\end{array}$

ab values within a row with no common superscripts are significantly different $(\mathrm{P}<0.05)$ 
In these samples, regardless of the assay method employed, the cellulase-treated feeds contained significantly $(\mathrm{P}<0.05)$ more $\beta$-glucanase than the control feeds and Xyl-A. Values obtained with the standard method were on average five times higher $(\mathrm{P}=0.001)$ than those obtained with the modified method (Table 9). The high endogenous enzyme activities found in the ileal samples made calculation of the recoveries meaningless.

Table 9. Average xylanase and $\beta$-glucanase activities in stomach and ileal samples measured by standard or modified methods.

\begin{tabular}{llll}
\hline Standard & Modified & sed & P-value \\
& & \\
\hline
\end{tabular}

Xylanase

$\begin{array}{lrrrr}\text { Stomach } & 6.0 & 2.8 & 4.4 & 0.001 \\ \text { Ileum } & 20.0 & 32.5 & 2.2 & 0.001\end{array}$

\section{$\beta$-glucanase}

$\begin{array}{lrrrr}\text { Stomach } & 19.0 & 14.0 & 2.7 & 0.071 \\ \text { Ileum } & 15.2 & 3.8 & 0.8 & 0.001\end{array}$

\section{DISCUSSION}

Enzyme application to animal feeds is a relatively new concept, and as a consequence, specific feed enzyme assays have not yet been developed. Given the conditions in the gastrointestinal (GI) tract of e.g. the pig, with pH ranging from approximately 2 to 8 (Kidder and Manners, 1978), one can argue that an enzyme assay carried out in fixed conditions cannot give the true picture of the actual activity in different parts of the gut. It, therefore, scems necessary to try and measure activities of supplementary enzymes in conditions similar to those of the digestive tract. Successful attempts have previously been made to measure xylanase and $\beta$-glucanase activity of ileal digesta of broiler chickens (Annison, 1992; Inborr \& Bedford, 1994). In these studies spectrophotometric assay methods based on dyed 
substrates were employed. Similar studies with pigs have not been reported. In the present study the absorbance measurements were carried out after the DNS reagent had reacted with the reducing sugars liberated during the incubation, resulting in a coloured complex. Thus these two methods are comparable.

Xylanase activity of the cellulase-treated wheat brans and diets was approximately three times higher than that of those treated with the xylanase preparation. This discrepancy may be due to variation in the assay method and the high dilution rate required to measure enyzme activities in the highly concentrated crude enzyme preparations. Hence even small variations in the assay will multiply many thousand times, which in turn can lead to underor overdosing of the products. However, the measured activity values of the diets were used as references when calculating the actual recoveries.

A change in assay temperature of $10^{\circ} \mathrm{C}$ means a change in enzyme activity by a factor of approximately 2 (Dixon et al., 1979). Consequently, xylanase activity values obtained by the modified method would be expected to be at a level of $50 \%$ of the ones obtained by the standard method used in this experiment, provided that the other assay parameters were the same. Deviations from this relationship should thus mainly reflect enzyme activity changes due to changes in $\mathrm{pH}$.

Xylanase activity values of the stomach samples measured by the modified method were approximately 50 per cent lower than those measured with the standard method regardless of time after feeding. Based on the above, this could be expected at $\mathrm{pH}$ close to the optimum for the enzymes. This indicates that the conditions of the standard method were more favourable to the enzymes and apparently lead to an overestimation the actual (true) activity in the stomach of the pigs. Also $\beta$-glucanase activities were lower with the modified method. In-vitro studies with a crude xylanase preparation and a commercial feed enzyme have shown that these enzymes are not readily denatured and possess an inherent stability to proteolysis (pepsin- $\mathrm{HCl}$ and pancreatin) and that the stability increased in the presence of suitable substrates (Inborr \& Grönlund, 1993). In their study the in-vitro incubations lasted 30 minutes, which was approximately the time elapsed between the consumption of the feeds and the first sampling of the stomach in the present experiment. The results of these two studies are in good agreement, since the rates of enzyme inactivation were of the same magnitude. However, both xylanase and $\beta$-glucanase activities decreased rapidly and were on average 16 and 46 per cent of the initial value at 4 hours after feeding, respectively, when 
measured by the standard method and 14 and 28 per cent of the initial value, respectively, when measured by the modified method. Thus there was an apparent loss of enzyme activity in these conditions. This is in contrast with the results by Inborr \& Bedford (1994), who reported full recovery of added $\beta$-glucanase in the proximal part of the small intestine of broiler chickens fed ad libitum. This discrepancy may be due to different $\mathrm{pH}$ and feed retention times between the two animal species.

The relatively high endogenous enzyme activities (control diets) measured in the ileal samples during the first two hours after feeding of the control diets is probably due to microbial activity in the lumen (Tables 7 and 8). It is conceivable that the main part of the first collection after feeding contained material from the previous feeding that had been subjected to microbial degradation for several hours, leading to increased concentration of fibre-degrading enzymes. Graham et al. (1986b) found that approximately 10 per cent of lactobacilli of pig ileal digesta were capable of degrading pectin and mixed-linked $\beta$-glucans when pigs were fed a diet based on barley and soybean meal. In the present study the main DF components were the arabinoxylans and $\beta$-glucans, which may explain the relatively high concentration of xylanase and $\beta$-glucanase in the ileum of the control pigs. During the two subsequent two-hour collections both xylanase and $\beta$-glucanase concentration of the control diet tended to decrease, whereas that of the enzyme-treated feeds generally increased. This observation supports the assumption that the endogenous enzyme activities found in the ileal samples immediately after feeding were a result of microbial fermentation, since 'fresh' material arriving at the terminal ileum would not have been subjected to microbial degradation to the same extent as 'old' material and hence would contain less background and more added enzyme activity. Moreover, since there were no differences in enzyme concentration between the control and the enzyme-treated feeds in the samples taken immediatley after feeding, one can assume that most of the added enzymes had been inactivated during the 12-hour time period between the feedings. With 'fresh' material arriving at the ileum (between 2 and 6 hours after feeding), the proportion of endogenous activity of total decreased based on values using the modified assay method. This indicates a certain degree of survivability of the added enzymes up to 6 hours after feeding (Tables 7 and 8). With the modified assay method, ileal xylanase activities were almost two times higher than when the standard method was employed. This indicates a considerable production of xylanase by the indigenous microflora, which was detectable by the modified 
but not the standard assay method. One can assume that microbes living in conditions of $\mathrm{pH}$ around 8 also produce enzymes for their own "digestion" with $\mathrm{pH}$ optima in this region. $\mathrm{pH}$ optima of xylanase, $\beta$ - and endo-glucanases produced by rumen bacteria vary between 5.8 and 6.9, which correspond to $\mathrm{pH}$ of rumen contents (Cheng et al., 1991). Cellulolytic and pectinolytic microbes have also been found in the small intestine of pigs (Chesson et al., 1985). Interestingly, with regard to $\beta$-glucanase activity, this relationship between the assay methods was reversed. It is possible that the $\beta$-glucanase production by the small intestinal microbes was very low on this diet and that differences between the two assay methods were due to different assay conditions ( $\mathrm{pH}$ and incubation time) or substrate affinity of the enzymes.

When enzyme activity values obtained at the same site by the two assay methods were compared, there was either a tendency to a significant (stomach $\beta$-glucanase activity) or a significant difference between the two methods employed. In three out of four cases, the modified method gave lower values than the standard. However, in only one of these three situations (xylanase in the stomach), the activity was approximately half of that of the standard method as expected based on the changes in assay temperature. Thus other factors than assay temperature appear to be involved such as $\mathrm{pH}$, enzyme origin and substrate affinity.

Based on these results it can be concluded that dietary xylanase and $\beta$-glucanase activities can be measured in the stomach and ileum of pigs with the assay methods employed. Although a great portion of the added enzyme activities were recovered in the stomach digesta samples immediately after feeding, enzyme activities decreased with time and were almost nil at the end of the small intestine 12 hours after feeding as indicated by the high endogenous activities found in the ileal samples immediately after feeding. When feed was present, considerable amounts of xylanase appeared to be produced by the microflora of the small intestine. The modified assay method gave generally significantly lower values than the standard, indicating a need for measuring gut enzyme activities in conditions similar to those found in the digestive tract in order to get a reliable picture regarding the actual enzyme activity. The two enzyme preparations employed appeared to behave differently in the two sections of the GI tract under study. 


\section{ACKNOWLEDGEMENTS}

The authors would like to thank Messrs J.G.M. Bakker, R.A. Dekker and J. Veldhuis for assisting with the sample collection and analysis. This investigation was funded by Financieringsoverlag Mest- en Ammoniakonderzoek, Wageningen, the Netherlands and Finnfeeds International Ltd., Marlborough, United Kingdom. 


\section{REFERENCES}

Annison, G. (1992). Commercial enzyme supplementation of wheat-based diets raises ileal glycanase activities and improves apparent metabolisable energy, starch and pentosan digestibilities in broiler chickens. Animal Feed Science and Technology 38, 105-121.

Bach Knudsen, K.E. \& Hansen, I. (1991). Gastrointestinal implications of wheat and oat fractions. 1. Digestibility and bulking properties of polysaccharides and other major constituents. British Journal of Nutrition 65, 217-232.

Cheng, K.-J., Forsberg, C.W., Minato, H. \& Costerton, J.W. (1991). Microbial ecology and physiology of feed degradation within the rumen. In Physiological Aspects of Digestion and Metabolism in Ruminants, Proceedings of the 7th International Symposium on Ruminant Physiology, pp 595-624. [T. Tsuda, Y. Sasaki and R. Kawashima, editors]. Tokyo: Academic Press.

Chesson, A., Richardson, A.J. \& Robertson, J.A. (1985). Fibre digestion and bacteriology of the digestive tract of pigs fed cereal and vetetable fibre. In Proceedings of the 3rd International Seminar on Digestive physiology in the Pig, pp. 272-275. [A. Just, J. Fernandez and H. Jorgensen, editors]. Copenhagen: National Institute of Animal Science.

Dixon, M., Webb, E.C., Thorne, C.J.R. \& Tipton, K.F. (1979). Enzymes, 3rd ed., New York: Academic Press.

Graham, H., Hesselman, K. \& Åman, P. (1986a). The influence of wheat bran and sugarbeet pulp on the digestibility of dietary components in a cereal-based pig diet. Journal of Nutrition 116, 242-251.

Graham, H., Hesselman, K., Jonsson, E. \& Åman, P. (1986b). Influence of $\beta$-glucanase supplementation on digestion of a barley-based diet in the pig gastrointestinal tract. Nutrition Reports International 34, 1089-1096.

Inborr, J. \& Bedford, M.R. (1993). Stability of feed enzymes to steam pelleting during feed processing. Animal Feed Science and Technology. (In press).

Inborr, J. \& Grönlund, A. (1993). Stability of feed enzymes in physiological conditions assayed by in-vitro methods. Agricultural Science in Finland 2, 125-132.

Kidder, D.E. \& Manners, M.J. (1978). Digestion in the pig. pp. 201. Scientechnica, Bath, U.K. ISBN 0856080225.

Leeuwen, van, P., Huisman, J., Verstegen, M.W.A., Baak, M.J., van Kleef, D.J., van Weerden, E.J. \& den Hartog, L.A. (1988). A new technique for collection of ileal chyme in pigs. In Proceedings of the 4th International Seminar on Digestive Physiology in the Pig, pp. 289-296. [L. Buraczewska, S. Buraczewski, B. Pastuszewska and T. Zebrowska, editors]. Jablonna: Polish Academy of Science. 
Low, A.G. (1985). The role of dietary fibre in digestion, absorption and metabolism. In Proceedings of the 3rd International Seminar on Digestive physiology in the Pig, pp 157-179 [A. Just, J. Fernandez and H. Jorgensen, editors]. Copenhagen: National Institute of Animal Science. pp. 157-179.

McClean, D. \& McCracken, K.J. (1992). Effects of enzyme supplementation on digestibility of wheat feed by weaned pigs. Proceedings of the Nutrition Society 51, 3.

Nahm, K.H. \& Carlson, C.W. (1985). Effects of cellulase from Trichoderma viride on nutrient utilisation by broilers. Poultry Science 64, 1536-1540.

Neudoerffer, T.S. \& Smith, R.E. (1969). Enzymic degradation of wheat bran to improve its nutritional value for monogastrics. Canadian Journal of Animal Science 49, 205-214.

Netherlands Normalisation Institute (1974). Test methods for feeding stuffs: determination of the moisture content. NEN 3332. Delft, The Netherlands.

Payne, R.W., Lane, P.W., Ainsłey, A.E., Dicknell, K.E., Digby, P.G.N., Harding, S.A., Leech, P.K., Simpson, H.R., Todd, A.D., Verrier, P.J., White, P.W., Gower, J.C., Tunnicliffe Wilson, G \& Paterson, L.J. (1987). Genstat 5 Reference manual. Oxford: Oxford University Press.

Schutte, J.B., van Kempen, G.J.M. \& Hamer, R.J. (1990). Possibilities to improve the utilisation of feed ingredients rich in non-starch polysaccharides for poultry. In Proceedings of the 8th European Poultry Conference, pp. 128-135. Barcelona, Spain.

Sumner, J.B. \& Somers, G.F. (1949). Dinitrosalisylic acid for glucose. In Laboratory experiments in biological chemistry, 2nd edition. New York: Academic Press. 


\title{
Effect of adding fibre and starch degrading enzymes to a barley/wheat based diet on performance and nutrient digestibility in different segments of the small intestine of early weaned pigs
}

\author{
J. Inborr ${ }^{*, a}$, M. Schmitz ${ }^{\mathrm{b}}$, F. Ahrens ${ }^{\mathrm{b}}$ \\ ainnfeeds International Ltd., Market House, High Street, Marlborough, SN8 1AA, UK \\ ${ }^{b}$ IS Forschungsgesellschaft für experimentelle Tierphysiologie und Tierernährung $\mathrm{mbH}$ und Co. KG, \\ Wiesenweg 10, D-2362 Wahlstedt, Germany
}

(Received 26 October 1992; accepted 11 May 1993)

\begin{abstract}
A total of 96 pigs were divided into 12 groups of eight and housed in flat-deck pens for 21 days. A basal diet based on barley (35\%), wheat $(35 \%)$ and soybean meal $(22 \%)$ was used as control or supplemented with either of two enzyme premixes ( $M$ and $C$ ), containing $\beta$-glucanase, xylanase and amylase. Both premixes contained the same sources of xylanase and amylase, whereas the $\beta$-glucanase in premix $\mathbf{M}$ was of a different Trichoderma longibrachiatum strain and produced under different conditions than the $\beta$-glucanase in premix C. Diets were fed ad libitum during the 3-week period, with weight gain and feed consumption recorded weekly. At the end of the experiment, two pigs from each pen were killed, the small intestine removed and divided into four sections of equal length. Nutrient and fibre component digestibilities were measured in the three lower sections.

Enzyme supplementation did not significantly influence weight gain or feed utilisation of the pigs during the experiment. Dry matter and starch digestibilities in the fourth quarter of the small intestine were improved $(P<0.05)$ by enzyme M. Both enzyme supplements increased $\beta$-glucan digestibility in the third and fourth quarter $(P<0.05)$. The digestibility of soluble NSP increased significantly $(P<0.05)$ in the third and fourth quarter due to enzyme supplementation, whereas there was no effect on the total NSP fraction. These results suggest that fibre and starch degrading enzymes are of potential benefit to early weaned pigs fed diets based on barley and wheat.
\end{abstract}

\section{Introduction}

Weaning from the sow imposes a major stress on the pig, which has been shown to cause a dramatic decrease in the production of, for example, pancreatic enzymes (Lindemann et al., 1986; Owsley et al., 1986). Furthermore, weaning involves a change of diet, both in terms of composition and physical

*Corresponding author. 
form. This has been shown to provoke changes in the composition of the pancreatic digestive enzymes (Mourot and Corring, 1979; McCracken, 1984; McCracken and Kelly, 1984). Also the change of environment usually associated with weaning in terms of temperature may influence the production of digestive enzymes (Szabo et al., 1976).

As the sow's milk is withdrawn and dry feed is introduced, the digestive system of the pig is challenged by a completely new set of chemical compounds such as vegetable protein, starch and fibre. The reduced secretion of digestive enzymes at this stage may lead to growth depression (Okai et al., 1976) and digestive disorders due to malabsorption (Hampson and Kidder, 1986 ) as a result of the reduced digestive capacity. In particular, the indigestible fibre components, such as the non-starch polysaccharides (NSP) may impede the digestion of protein and energy (Low, 1985). Enzyme supplementation of pig starter feeds could therefore serve two purposes. First, to complement the production of the pig's own digestive enzymes, and second, to increase the digestibility of the fibre components of the diet.

In many European countries, wheat and barley are the most commonly used cereal grains in pig and poultry feeds. In poultry, the soluble fibre fractions of barley (mixed-linked $\beta$-glucans) and wheat (pentosans) have been shown to be responsible for the reduced nutrient digestibility in the small intestine (White et al., 1981; Bedford et al., 1991). In a large number of experiments, enzyme supplementation of barley and wheat based feeds has resulted in significant improvements in bird performance and the energy value of the diet (Chesson, 1987; Dierick, 1989). More recently, Bedford and Classen (1992) have shown that the improved performance of broiler chickens fed enzymesupplemented feeds correlates to a high degree with reduced digesta viscosity in the small intestine. There is also evidence that the mixed-linked $\beta$-glucans in barley may reduce the productive value of barley in young pigs, since supplementation of barley based feeds with $\beta$-glucanases has resulted in improved performance (Thomke et al., 1980) and nutrient digestibility (Markström et al., 1985; Graham et al., 1986, 1989; Inborr et al., 1991). Furthermore, enzyme treatment of barley reduced the incidence and severity of diarrhoea in early weaned piglets (Inborr and Ogle, 1988). The mechanisms involved are still unclear.

The objectives of this experiment were to investigate the effect of adding two enzyme mixtures, containing $\beta$-glucanase, xylanase and amylase, to a barley/wheat based pig starter feed on performance and digestibility of nutrients and fibre components in the small intestine of early weaned pigs.

\section{Materials and methods}

\section{Enzyme premixes}

Two enzyme premixes were produced to contain equal concentration of $\beta$ glucanase, xylanase and $\alpha$-amylase (Table 1). Both preparations contained 
Table 1

Measured activities of the enzyme premixes

\begin{tabular}{lcc}
\hline Activity & Premix M & Premix C \\
\hline$\beta$-Glucanase $\left(\mathrm{IRVU} \mathrm{g}^{-1}\right)$ & 34.9 & 40.7 \\
Xylanase $\left(\mathrm{Ug}^{-1}\right)$ & 590 & 740 \\
$\alpha$-Amylase $\left(\mathrm{U} \mathrm{g}^{-1}\right)$ & 3300 & 3300 \\
\hline
\end{tabular}

the same sources of xylanase (Trichoderma viride) and $\alpha$-amylase (Bacillus subtilis), whereas two different $\beta$-glucanase preparations were employed.

The two $\beta$-glucanases (MF and CL), both from Genencor International Ltd., Helsinki, Finland, were produced by different Trichoderma longibrachiatum strains under different conditions. This resulted in different activity spectra, and $\mathrm{pH}$ and temperature optima of the enzymes. At $60^{\circ} \mathrm{C}$, the $\mathrm{pH}$ optimum of the MF cellulase activity was quite broad, between 3.5 and 5.5, whereas that of the CL product was much narrower, between 3.8 and 4.2.

\section{Diets}

The basal diet was formulated to contain $18 \%$ crude protein, $1.2 \%$ lysine, $0.72 \%$ methionine + cystine, $0.78 \%$ threonine and a metabolisable energy content of 13.2 MJ per $\mathrm{kg}$ feed (Table 2). The basal mash diet was ground through a $4 \mathrm{~mm}$ sieve and then divided into three batches of approximately equal size. Enzyme premix M (containing enzyme MF) was added to one of the batches at $1.0 \mathrm{~g} \mathrm{~kg}^{-1}$ to form Diet $\mathrm{M}$ and enzyme premix C (enzyme CL) at $0.95 \mathrm{~g} \mathrm{~kg}^{-1}$ to form Diet C. Based on the enzyme activity analysis, enzyme premixes $\mathrm{C}$ thus provided slightly more $\beta$-glucanase and xylanase and less $\alpha$ amylase per $\mathrm{kg}$ feed than premix $\mathrm{M}$. The third batch was unsupplemented and used as a control (Diet $\mathrm{A})$. Titanium oxide $\left(\mathrm{TiO}_{2}\right)$ was added as an undigestible marker at $5 \mathrm{~g} \mathrm{~kg}^{-1}$ for the digestibility study.

\section{Pigs}

A total of 96 crossbred (German Landrace $\times$ Duroc) barrows weaned at an age of 21-24 days were divided into groups of eight and randomly assigned to one of the three treatments by litter origin and weight. The pigs were housed in flat-deck pens at an initial room temperature of $26^{\circ} \mathrm{C}$, which was decreased to $22^{\circ} \mathrm{C}$ by the end of the experiment. Water was freely available from nipple drinkers placed in the pens. Lights were on for $12 \mathrm{~h}$ a day between 05.30 and $17.30 \mathrm{~h}$. 
Table 2

Composition and calculated content of chemical constituents of the basal diet ( $\mathrm{g} \mathrm{kg}^{-1}$ as fed)

Ingredient

Composition

Wheat 348

Barley 348

Soybean meal (CP 44\%) $\quad 220$

Soya oil 30

Vitamin/Mineral premix ${ }^{1} \quad 49$

Titanium oxide 5

Calculated composition

Crude protein $\quad 180$

Crude fat $\quad 45$

Crude fibre $\quad 40$

Lysine $\quad 12.0$

Methionine and cystine $\quad 7.2$

$\begin{array}{ll}\text { Threonine } & 7.8\end{array}$

Calcium $\quad 9.0$

Phosphorous $\quad 7.0$

Metabolisable energy $\left(\mathrm{MJ} \mathrm{kg}^{-1}\right)^{2} \quad 13.2$

'The premix supplied per kilogram diet: retinyl acetate, $722 \mu \mathrm{g}$; cholecalciferol, $6 \mu \mathrm{g}$; 2-dl- $\alpha$-tocopherylacetate, $13.2 \mathrm{mg}$; vitamin $B_{1}, 1.2 \mathrm{mg}$; vitamin $B_{2}, 3.6 \mathrm{mg}$; vitamin $B_{6}, 1.8 \mathrm{mg}$; vitamin $B_{12}, 18 \mu \mathrm{g}$; vitamin $\mathrm{K}_{3}, 0.6 \mathrm{mg}$; folic acid, $0.36 \mathrm{mg}$; niacin, $15 \mathrm{mg}$; biotin, $0.06 \mathrm{mg}$; pantothenic acid, $10.8 \mathrm{mg}$; choline, $0.48 \mathrm{~g}$; Ca, $7.9 \mathrm{~g} ; \mathrm{P}, 3.3 \mathrm{~g}$; Na, $1.6 \mathrm{~g} ; \mathrm{Fe}, 96 \mathrm{mg}$; Mg, $0.48 \mathrm{~g} ; \mathrm{Mn}, 3.8 \mathrm{mg} ; \mathrm{Zn}, 96 \mathrm{mg} ; \mathrm{Cu}, 6 \mathrm{mg}$; I, $0.17 \mathrm{mg}$; Se, $0.3 \mathrm{mg}$; L-lysine-HCl, $4.1 \mathrm{~g}$; DL-methionine, $1.5 \mathrm{~g}$; L-threonine, $1.5 \mathrm{~g}$; salinomycin 40 $\mathrm{mg}$.

${ }^{2}$ Calculated according to DLG (1991).

Performance study

The experimental diets were fed ad libitum for 20 days. The pigs were weighed individually on Days 1, 8, 15 and 21 and feed consumed per pen was recorded on Days 8,15 and 21, thus dividing the experiment into two periods of 7 days and one period of 6 days. Live weight gains and feed consumption were calculated for all three periods and feed conversion ratios for periods two and three, since a few pigs lost weight during the first period. Health status was monitored daily and any abnormalities recorded.

Digestibility study

On Days 21 and 22 of the experiment, pigs weighing between 10 and $13 \mathrm{~kg}$ were killed and digesta was collected from the small intestine. Each day, four pigs per treatment (one pig from each pen) were randomly selected at least 3 $\mathrm{h}$ after the time the lights were switched on in the morning. Thus eight pigs per treatment were used for digestiblity measurements. 
Pigs were killed and the small intestine was ligated at the pylorus and the ileocaecal junction. Then the mesentry was cut and the small intestine divided into four segments of equal length. Owing to the small amount of digesta, the first segment was discarded. Digesta was gently squeezed out from each single segment into separate plastic containers. The gut was then rinsed with a saline solution to wash out any remaining digesta and the washing added to the digesta sample in the plastic container. Digesta samples were immediately put into a freezer for storage at $-20^{\circ} \mathrm{C}$. Before analysis, the digesta samples were freeze-dried and ground through a $0.5 \mathrm{~mm}$ sieve.

\section{Chemical analysis}

The dry matter content of the feeds was determined after the samples had been kept at $105^{\circ} \mathrm{C}$ for $4 \mathrm{~h}$, and the dry matter content of the digesta samples by freeze drying for $96 \mathrm{~h}$.

Nitrogen was determined by the Kjeldahl procedure, crude fat by petroleum ether extraction after acid $(\mathrm{HCl})$ hydrolysis, crude fibre by the method of VDLUFA (1975) and starch enzymatically by the method of Brandt et al. (1987). Ash content of the feeds was determined after the samples were ashed at $550^{\circ} \mathrm{C}$ overnight.

Total NSP content was determined by employing the method of Englyst and Hudson (1987) with the following modifications: the enzymes employed were Termamyl $300 \mathrm{~L}$ and Promozyme (both Novo Nordisk a/s, Copenhagen, Denmark). Isolated fibre polysaccharides were hydrolysed for $0.5 \mathrm{~h}$ at $25^{\circ} \mathrm{C}$ in $12 \mathrm{M} \mathrm{H}_{2} \mathrm{SO}_{4}$, followed by $2 \mathrm{~h}$ at $100^{\circ} \mathrm{C}$ in $1 \mathrm{M} \mathrm{H}_{2} \mathrm{SO}_{4}$. Monomers were then derivatised to their alditol acetates and quantified by gas chromatography (SP-2340 column).

The soluble NSP content was determined by applying the same method as above after the sample had been extracted in $0.2 \mathrm{M}$ phosphate buffer ( $\mathrm{pH} 7$ ) for $60 \mathrm{~min}$, the resultant supernatant liquid destarched by thermophilic amylase and pullulanase and the soluble NSP components precipitated with an $80 \%$ ethanolic solution. Beta-glucan was determined by the method of McCleary and Codd (1991), using reagents supplied by Megazyme Pty Ltd. (North Rocks, NSW, Australia). Titanium oxide was measured according to the method of Brandt and Allam (1987).

\section{Enzyme activity analysis}

A $10 \mathrm{~g}$ feed sample was weighed into a $100 \mathrm{ml}$ volumetric flask. Distilled water was added to $100 \mathrm{ml}$ and the suspension stirred for $30 \mathrm{~min}$ in room temperature and then filtered through a glass fibre filter (Macherey Nagel $85 / 90$ ). The extract was diluted to the appropriate concentration with buffer solutions according to the methods employed. 
Beta-glucanase (EC 3.2.1.6; endo- $\beta$-(1, 3) (1, 4)-glucanase) activity was determined viscosimetrically by employing the method described by Bathgate (1979) with minor modifications ( $\mathrm{pH}$ adjusted to 4.0 by $0.5 \mathrm{M}$ sodium acetate buffer and initial reciprocal viscosity of the substrate solution was 0.13 ). This method measures the reduction in substrate viscosity and enzyme activity was expressed as the increase in reciprocal viscosity (IRV).

After enzyme addition, four to six flow times were determined over a 30 min time period in an Ostwald capillary viscometer (Model No. II, 75-100 $\mathrm{s}$ ), immersed in a water bath at $30^{\circ} \mathrm{C}$. The flow times were used to calculate the reciprocal specific viscosities, using the equation:

$$
1 / \eta_{\mathrm{sp}}=\frac{\mathrm{d} T_{0}}{\mathrm{~d} T_{S}-\mathrm{d} T_{0}}
$$

where $1 / \eta_{\mathrm{sp}}$ is the reciprocal specific viscosity, $\mathrm{d} T_{0}$ is the flow time of the buffer and $\mathrm{d} T_{S}$ is the flow time of the substrate-enzyme solution.

Beta-glucanase activity was expressed as IRV and calculated using the equation:

$\beta$-glucanase, IRV Units $\mathrm{g}^{-1}=\frac{k \times D}{V}$

where $k$ is the slope of the curve plotted from the reciprocal specific viscocity versus hydrolysis time ( $\mathrm{min}), D$ is the total dilution factor and $V$ is the sample volume. One IRV unit is defined as the change of one $\left(1 / \eta_{\mathrm{sp}}\right) \mathrm{min}^{-1}$

Xylanase (EC 3.2.1.8; endo- $(1,4)-\beta$-xylanase) activity was determined using $1 \%$ oat spelt xylan (Fluka 95590 ) in $0.05 \mathrm{M}$ sodium acetate buffer, pH 5.3 , as substrate. One $\mathrm{ml}$ of enzyme dilution was incubated with $1 \mathrm{ml}$ of substrate solution at $50^{\circ} \mathrm{C}$ for $60 \mathrm{~min}$. Reducing sugars formed were assayed by adding $3 \mathrm{ml}$ of 3, 5-dinitrosalicylic acid (DNS) reagent, boiling for $5 \mathrm{~min}$ and measuring the absorbance at $540 \mathrm{~nm}$. One xylanase unit is the amount of enzyme that releases $1 \mu \mathrm{mol}$ of reducing sugars (expressed as xylose) in 1 $\min$.

Alpha-amylase (EC 3.2.1.1) activity was determined using the Phadebas $®$ Amylase Test kit (Pharmacia Diagnostics AB, Uppsala, Sweden ), with buffer ( $9.0 \mathrm{~g} \mathrm{NaCl}, 2.0 \mathrm{~g}$ bovine serum albumin and $2.2 \mathrm{~g} \mathrm{CaCl}_{2}$ in $1000 \mathrm{ml}$ distilled water; pH 6.7) used instead of distilled water for dilution of the sample and dissolution of the tablet. One $\alpha$-amylase unit is the amount of enzyme needed to hydrolyse one $\mu \mathrm{mol}$ of glycosidic linkages in $1 \mathrm{~min}$ under the analytical conditions.

\section{Calculations and statistical analysis}

Pig live weight gains are reported as treatment means based on individual 
pig weights, and feed intake is reported as treatment means based on individual pen (replicate) values. Feed conversion ratio is calculated as feed intake divided by mean replicate live weight gain.

Digestibility coefficients of the analysed components are reported as treatment mean values (eight pigs per treatment) and were calculated using the formula:

$$
1-\frac{\text { nutrient concentration in digesta } \times \mathrm{TiO}_{2} \text { concentration in feed }}{\text { nutrient concentration in feed } \times \mathrm{TiO}_{2} \text { concentration in digesta }}
$$

Normal distribution of data and equality of variances were tested according to Bartlett (Sachs, 1992). Data on weight gain, feed intake and feed conversion ratio of the 3-week period was normally distributed and showed equal variances. They were analysed by ANOVA with diet as factor. Digestibilities were normally distributed and analysed separately for each small intestinal section by ANOVA with diet as factor. This procedure was adopted because variances in the single segments were different and could not be made equal by transformation calculation. Differences between means were tested according to Scheffe (Sachs, 1992).

\section{Results}

Diets

On an air dry basis, the total $\beta$-glucan content of the diets ranged between 1.2 and $1.3 \%$ and the total NSP between 10.8 and $11.7 \%$ (Table 3). Glucose, uronic acid, xylose and arabinose were the most abundant NSP sugars of the diets, with rhamnose, fucose and mannose in concentrations less than $1 \%$. Solubility of the NSP sugars ranged from approximately $17 \%$ (xylose) to $68 \%$ (glucose) with an average of $40 \%$.

Measured enzyme activities of the supplemented diets were close to the calculated values for $\beta$-glucanase and xylanase, whereas that of $\alpha$-amylase in Diet $\mathrm{M}$ was lower (Table 3 ). Endogenous $\beta$-glucanase and xylanase activities of the unsupplemented diet were relatively high and represented approximately $15 \%$ of the total $\beta$-glucanase and $57 \%$ of the total xylanase activity of the supplemented diets. This high value for endogenous xylanase may have resulted from high endogenous activity in, for example, wheat or from components in the feed (e.g. metal ions) reacting with the DNS reagent causing a colour reaction, which then increases the spectrophotometric absorbance of the solution. The endogenous $\alpha$-amylase activity of the unsupplemented diet was low. 
Table 3

Chemical composition ( $\mathrm{g} \mathrm{kg}^{-1}$ as fed ) and measured enzyme activities of the experimental diets for pigs

\begin{tabular}{|c|c|c|c|}
\hline \multirow[t]{2}{*}{ Chemical constituent } & \multicolumn{3}{|c|}{ Experimental diet } \\
\hline & A & M & $\mathrm{C}$ \\
\hline Crude protein & 182 & 181 & 181 \\
\hline Crude fat $(\mathrm{HCl})$ & 55 & 55 & 52 \\
\hline Ash & 65 & 66 & 66 \\
\hline Starch & 397 & 397 & 399 \\
\hline Mixed-linked $\beta$-glucans & 13 & 12 & 13 \\
\hline \multicolumn{4}{|c|}{ Non-starch polysaccharide residues } \\
\hline Total & 117 & 108 & 114 \\
\hline \multicolumn{4}{|l|}{ Soluble } \\
\hline Arabinose & 5 & 5 & 5 \\
\hline Xylose & 5 & 6 & 5 \\
\hline Galactose & 5 & 6 & 6 \\
\hline Glucose & 23 & 26 & 25 \\
\hline Uronic acid & 4 & 4 & 4 \\
\hline Mannose & 2 & 2 & 1 \\
\hline Rhamnose & -1 & - & - \\
\hline Fucose & - & - & - \\
\hline Total & 44 & 49 & 46 \\
\hline \multicolumn{4}{|l|}{ Insoluble } \\
\hline Arabinose & 14 & 12 & 12 \\
\hline Xylose & 25 & 21 & 25 \\
\hline Galactose & 5 & 4 & 4 \\
\hline Glucose & 18 & 12 & 16 \\
\hline Uronic acid & 5 & 4 & 5 \\
\hline Mannose & 4 & 4 & 4 \\
\hline Rhamnose & 1 & 1 & 1 \\
\hline Fucose & 1 & 1 & 1 \\
\hline Total & 73 & 59 & 68 \\
\hline \multicolumn{4}{|l|}{ Enzyme activities } \\
\hline$\beta$-glucanase (IRVU kg-1) & 6 & 34 & 36 \\
\hline xylanase $\left(\mathrm{U} \mathrm{g}^{-1}\right)$ & 1.0 & 1.7 & 1.8 \\
\hline$\alpha$-amylase $\left(\mathrm{U} \mathrm{g}^{-1}\right)$ & $<0.1$ & 2 & 3 \\
\hline
\end{tabular}

'Concentration under detection limit.

Performance study

There were no mortalities or cases of illness among the treatment groups during the experiment.

There were no significant differences in either weight gain or feed utilisa- 
Table 4

Weight gain, feed intake and feed conversion ratio of pigs in the treatment groups during the experimental period (values are means \pm SEM $)^{1}$

\begin{tabular}{lrrr}
\hline & \multicolumn{1}{c}{ Diet A } & Diet M & \multicolumn{1}{c}{ Diet C } \\
\hline Weight gain $\left(g_{\text {day }}{ }^{-1}\right)$ & & & \\
Week 1 & $56 \pm 10$ & $64 \pm 11$ & $39 \pm 11$ \\
Week 2 & $203 \pm 12$ & $209 \pm 13$ & $210 \pm 17$ \\
Week 3 & $379 \pm 16$ & $423 \pm 26$ & $392 \pm 18$ \\
Weeks 1-3 & $204 \pm 9$ & $223 \pm 10$ & $205 \pm 13$ \\
Feed intake $\left(g_{\text {day }}^{-1}\right)$ & & & \\
Week 1 & $106 \pm 6$ & $114 \pm 9$ & $109 \pm 9$ \\
Week 2 & $254 \pm 17$ & $280 \pm 8$ & $231 \pm 17$ \\
Week 3 & $517 \pm 17$ & $566 \pm 17$ & $541 \pm 33$ \\
Weeks 1-3 & $281 \pm 11$ & $307 \pm 10$ & \\
& & & \\
Feed: gain & & & $1.13 \pm 0.07$ \\
Week 2 & $1.20 \pm 0.02$ & $1.36 \pm 0.09$ & $1.38 \pm 0.02$ \\
Week 3 & $1.37 \pm 0.02$ & $1.34 \pm 0.04$ & $1.39 \pm 0.06$ \\
Weeks 1-3 & $1.38 \pm 0.02$ & $1.38 \pm 0.02$ & \\
\hline
\end{tabular}

'No significant treatment effects observed $(P>0.05)$.

tion of the pigs of the three treatment groups during the overall experimental period (Table 4).

\section{Digestibility study}

Dry matter digestibility tended to be higher in the second and third quarter, and was significantly higher $(P<0.05)$ in the fourth quarter of the small intestine of pigs fed the enzyme supplemented diets (Table 5). Crude protein digestibility was numerically but not significantly higher in the pigs fed the enzyme-treated diets compared with the pigs fed the control diet.

Starch digestibility was significantly higher $(P<0.05)$ in the fourth quarter of the small intestine of pigs fed Diet $\mathrm{M}$ compared with the control pigs.

In pigs fed the basal diet (Diet A), the digestibility of $\beta$-glucans was generally low and on the same level in all segments (Table 5). Supplementation of the basal diet with the enzymes significantly $(P<0.05)$ increased the digestibility of $\beta$-glucans in the third and fourth section of the small intestine.

The digestibility of the soluble NSP fraction of the unsupplemented diet was negative in all three sections of the small intestine investigated, with the lowest value in the second and the highest in the fourth quarter (Table 6). Enzyme supplementation significantly $(P<0.05)$ increased the digestibility of soluble NSP in the third and fourth quarters but did not have any significant effect in the second quarter. 
Table 5

Digestibility of dry matter, crude protein, starch and mixed-linked $\beta$-glucans in the last three quarters of the small intestine of the pigs (treatment means \pm SEM)

\begin{tabular}{lllll}
\hline $\begin{array}{l}\text { Section of the } \\
\text { small intestine }\end{array}$ & Nutrient & Diet A & Diet M & Diet C \\
\hline Second quarter & Dry matter & $0.245 \pm 0.030$ & $0.270 \pm 0.052$ & $0.321 \pm 0.029$ \\
& Protein & $0.310 \pm 0.055$ & $0.420 \pm 0.018$ & $0.327 \pm 0.051$ \\
& Starch & $0.332 \pm 0.052$ & $0.509 \pm 0.035$ & $0.379 \pm 0.045$ \\
& $\beta$-glucan & $0.340 \pm 0.021$ & $0.447 \pm 0.069$ & $0.559 \pm 0.076$ \\
Third quarter & Dry matter & $0.526 \pm 0.027$ & $0.550 \pm 0.027$ & $0.589 \pm 0.014$ \\
& Protein & $0.619 \pm 0.029$ & $0.646 \pm 0.032$ & $0.699 \pm 0.010$ \\
& Starch & $0.807 \pm 0.017$ & $0.857 \pm 0.030$ & $0.854 \pm 0.021$ \\
& $\beta$-glucan & $0.304 \pm 0.055$ & $0.578 \pm 0.029^{\mathrm{a}}$ & $0.565 \pm 0.070^{\mathrm{a}}$ \\
Fourth quarter & Dry matter & $0.643 \pm 0.008$ & $0.679 \pm 0.006^{\mathrm{a}}$ & $0.671 \pm 0.009$ \\
& Protein & $0.768 \pm 0.018$ & $0.784 \pm 0.013$ & $0.779 \pm 0.011$ \\
& Starch & $0.949 \pm 0.008$ & $0.977 \pm 0.006^{\mathrm{a}}$ & $0.968 \pm 0.004$ \\
& $\beta$-glucan & $0.321 \pm 0.030$ & $0.719 \pm 0.031^{\mathrm{a}}$ & $0.719 \pm 0.033^{\mathrm{a}}$ \\
\hline
\end{tabular}

${ }^{a}$ Treatment mean value is significantly different $(P<0.05)$ from control (Diet A).

Table 6

Digestibility of total and soluble non-starch polysaccharides in the last three quarters of the small intestine of the pigs (treatment means \pm SEM)

\begin{tabular}{llrrr}
\hline $\begin{array}{l}\text { Section of the } \\
\text { small intestine }\end{array}$ & $\begin{array}{l}\text { Non-starch } \\
\text { polysaccharide } \\
\text { fraction }\end{array}$ & \multicolumn{1}{l}{ Diet A } & Diet M & \multicolumn{1}{l}{ Diet C } \\
\hline Second quarter & Total & $0.142 \pm 0.055$ & $0.032 \pm 0.098$ & $0.092 \pm 0.052$ \\
& Soluble & $-0.385 \pm 0.080$ & $-0.304 \pm 0.122$ & $-0.328 \pm 0.086$ \\
Third quarter & Total & $0.045 \pm 0.055$ & $0.005 \pm 0.049$ & $0.032 \pm 0.056$ \\
& Soluble & $-0.149 \pm 0.046$ & $0.091 \pm 0.048^{\mathrm{a}}$ & $0.091 \pm 0.050^{\mathrm{a}}$ \\
Fourth quarter & Total & $0.013 \pm 0.025$ & $-0.004 \pm 0.042$ & $0.001 \pm 0.039$ \\
& Soluble & $-0.054 \pm 0.030$ & $0.219 \pm 0.016^{\mathrm{a}}$ & $0.160 \pm 0.030^{\mathrm{a}}$ \\
\hline
\end{tabular}

aTreatment mean value is significantly different $(P<0.05)$ from control (Diet A).

\section{Discussion}

Enzyme supplementation of pig starter diets has given inconsistent responses in terms live weight gain and feed utilisation, whereas the response to enzymes in broiler chickens has been much more consistent (Chesson, 1987; Dierick, 1989). Recent studies with broilers have shown that reduced digesta viscosity due to enzyme supplementation is the main factor responsible for the performance response in diets based on barley (Bedford, 1993), wheat and rye (Bedford and Classen, 1992). In contrast, digesta viscosity in the small intestine of early weaned pigs fed hulless barley supplemented with $\beta$ glucanase did not correlate with improved performance (Inborr et al., 1991), suggesting that viscosity is not a factor reducing the nutritive value of barley 
in young pigs. Interestingly, however, in the same study, protein digestibility decreased as digesta viscosity increased in the first and third quarter of the small intestine in pigs fed rye-based diets.

In the present study, enzyme supplementation increased the digestibility of starch in the small intestine. This is in contrast with the results of a previous study (Inborr et al., 1991) with pigs fed a hulless barley-based diet supplemented with a single $\beta$-glucanase source. The use of $\alpha$-amylase in combination with fibre-degrading enzymes in the present experiment may explain the increased starch digestibility. Graham et al. $(1986,1988,1989)$ also reported increased ileal starch digestibility in pigs fed enzyme-supplemented diets based on barley or barley and pollard.

Since starch was the major source of energy in the diets employed, increased weight gain and improved feed utilisation could perhaps have been expected due to the increased digestibility. However, considering the magnitude of improvement, which was in the range of 2.5 percentage units at the end of the small intestine, corresponding to approximately $4 \mathrm{~g}$ less feed consumption per day (assuming equal weight gain) and a feed conversion ratio reduction of 0.02 , the lack of performance response is not surprising.

Increased starch digestibility in the upper small intestine effectively means that less easily fermentable substrate arrives in the lower digestive tract to be fermented by the microbes. This would reduce the proliferation and activity of the microflora in the caecum and large intestine (Bach Knudsen et al., 1991 ), thus possibly reducing digestive upsets. Inborr and Ogle (1988) reported reduced incidence and severity of diarrhoea in pigs fed enzyme-treated barley, while Böhme (1990) found a reduced need for antibiotic treatments due to less digestive disorders in pigs fed feeds supplemented with a $\beta$-glucanase and amylase containing enzyme preparation. In the present experiment, none of the treatment groups showed any signs of digestive disorders.

Protein digestibility was not significantly increased by enzyme supplementation. This is in contrast with the results by Inborr et al. (1991), who reported improved protein digestibility over the entire small intestine and Graham et al. (1988), who obtained an increased ileal protein digestibility in pigs fed barley-based diets supplemented with $\beta$-glucanase.

Addition of the enzyme supplements markedly increased the digestibility of $\beta$-glucans in the third and fourth quarters of the small intestine. This is in agreement with the results by Graham et al. $(1988,1989)$. Ileal digestibility of $\beta$-glucan in the pig seems to increase with age (Graham et al., 1988) but is also influenced by the source and solubility of the $\beta$-glucans (Bach Knudsen and Hansen, 1991). In a pig of about $20 \mathrm{~kg}$ live weight, $\beta$-glucan digestibility in the terminal ileum was reported to be about $40 \%$ (Graham et al., 1988), which is higher than the results in this experiment with pigs weighing between 10 and $13 \mathrm{~kg}$. This discrepancy may be due to lower microbial activity in the smaller pigs, resulting in less degradation of the $\beta$-glucans. 
Although digesta viscosity in the small intestine has not been proved to be a factor influencing the performance of barley fed pigs (Inborr et al., 1991), it is possible that soluble $\beta$-glucans increase the viscosity of the gastric content. This, in turn, may alter the rate of gastric emptying (Potkins et al., 1991) and the size of particles passing through the pyloric sphincter into the small intestine (Meyer et al., 1986), hereby affecting the rate end efficiency of digestion. Consequently, the increased digestibility of $\beta$-glucans in the presence of enzymes observed in the third quarter and a similar tendency in the second quarter of the small intestine may indicate more rapid degradation higher up in the gastrointestinal tract, for example in the stomach. This would mean reduced viscosity and better conditions for the digestion of starch and protein in the duodenum and jejunum due to better gastric function.

The digestibility of the soluble NSP fraction of the unsupplemented diet was negative in all segments of the small intestine. This is in accordance with the results obtained by Vervaeke et al. (1991) and is a consequence of fibres being solubilised as they pass through the upper parts of the gastrointestinal tract. The digestibility coefficients were approaching zero as the digesta passed through the small intestine. This is likely to be a result of the microbial degradation of these carbohydrates. Graham et al. (1986) showed that, for example lactobacilli from the small intestine are capable of degrading pectins and $\beta$-glucans.

Since soluble fibres of wheat and barley tend to increase digesta viscosity, thereby impairing digestion (White et al., 1981; Bedford and Classen, 1992), this solubilisation of fibres may well reduce the efficiency of digestion in the young pig. Enzyme supplementation did not have any effect on the digestibility of the soluble NSP in the second quarter of the small intestine and it may be that the rate of solubilisation was much greater than the rate by which the added enzymes were capable of degrading these fibres. In the third and fourth quarter, enzyme supplementation significantly increased the digestibility of the soluble NSP, which resulted in positive digestibility coefficients as opposed to the negative value of the control diet. This, together with the increased starch and dry matter digestibilities, would strongly suggest that the enzymes are still active in the upper jejunum and ileum and can improve the efficiency of digestion.

Based on the digestibility of the total and soluble NSP, some degradation of insoluble NSP appeared to take place in the small intestine. Vervaeke et al. ( 1991 ) measured an average of $21 \%$ degradation of insoluble NSP in the ileum of pigs fed diets containing cereal grains (minimum 25\%), sugar beet pulp, wheatbran and alfalfa. It is possible that these diets contained more easily fermentable components than those employed in the present experiment. Bach Knudsen and Hansen (1991) and Bach Knudsen et al. (1991) found that the recovery of insoluble NSP in the ileum of growing pigs was lower when wheat flour was fed alone compared with wheat flour fed with oat bran but they 
could not find any difference between these treatments in terms of microbial activity in the last third of the small intestine. On the other hand, feeding rolled oats resulted in almost full recovery of insoluble NSP in the ileum despite the highest microbial activity, indicating that the source and structure of carbohydrates influences the degradation of this fraction in the small intestine of pigs.

It seems that fibre-degrading enzymes, whether added to the feed or produced by the gut microflora, have a preference for solubilised substrates over insoluble, which is why enzyme supplementation in this experiment increased the digestibility of soluble NSP but had no effect on the total NSP fraction. This is a fortunate feature of exogenous enzymes, since the soluble fibres are probably interfering more with food digestion than the insoluble ones. This possibly means greater potential for increasing the efficacy of feed utilisation by enzyme supplementation of feeds based on ingredients high in soluble fibre.

There was no difference in efficacy between the two enzyme supplements employed. This suggests that differences between the two fungal $\beta$-glucanases in terms of pH optima and activity spectra were of insignificant importance. One could possibly expect greater differences between fungal and bacterial sources of $\beta$-glucanase, since they would differ more in terms of $\mathrm{pH}$ optima and substrate specificity than two sources of either fungal or bacterial origin.

The results from this experiment show that enzyme supplementation significantly increased the digestibility of starch and fibre components, but that the magnitude of improvement was too small to give a significant improvement in growth performance or feed utilisation of the pigs. However, these results show the potential benefits of fibre and starch degrading enzymes in barley/wheat based pig starter feeds. They also give some indications regarding the mode of action of the added enzymes in that the site of digestion and absorption of nutrients seem to have been shifted upwards in the small intestine when enzymes were added. Whether this apparent change in the rate of digestion is due to reduced gut viscosity or simply to alleviation of the impeding effects of fibre needs to be further investigated.

\section{Acknowledgements}

The authors would like to thank Jari Puhakka at the Cultor Ltd. Technology Centre, Kantvik, Finland, for carrying out the enzyme activity analysis. This work was funded by Finnfeeds International Ltd., Wiltshire, UK.

\section{References}

Bach Knudsen, K.E. and Hansen, I., 1991. Gastrointestinal implications in pigs of wheat and oat fractions. 1. Digestibility and bulking properties of polysaccharides and other major constituents. Br. J. Nutr., 65: 217-232. 
Bach Knudsen, K.E., Borg Jensen, B., Andersen, J.O. and Hansen, I., 1991. Gastrointestinal implications in pigs of wheat and oat fractions. 2. Microbial activity in the gastrointestinal tract. Br. J. Nutr., 65: 233-248.

Bathgate, G.N., 1979. The determination of endo- $\beta$-glucanase activity in malt. J. Inst. Brew., 85: 92-94.

Bedford, M.R., 1993. Mode of action of feed enzymes. J. Applied Poultry Res., Vol. 2: 85-92.

Bedford, M.R. and Classen, H.L., 1992. Reduction of intestinal viscosity through manipulation of dietary rye and pentosanase concentration is effected through changes in the carbohydrate composition of the intestinal aqueous phase and results in improved growth rate and food conversion efficiency of broiler chicks. J. Nutr., 122: 560-569.

Bedford, M.R., Classen, H.L. and Campbell, G.L., 1991. The effect of pelleting, salt and pentosanase on the viscosity of intestinal contents and the performance of broilers fed rye. Poult. Sci., 70: 1571-1577.

Böhme, H., 1990. Experiments on the effect of enzyme supplements as a growth promotor for piglets. Landbauforsch. Voelkenrode, 40(3): 213-217.

Brandt, M. and Allam, S.M., 1987. Analytik von $\mathrm{TiO}_{2}$ im Darminhalt und Kot nach Kjeldahlaufschluss. Arch. Anim. Nutr., 37: 453-454.

Brandt, M., Schuldt, A. Mannekorpi, P. and Vearasilp, T., 1987. Zur enzymatischen Stärkebestimmung im Darminhalt und Kot von Küken mit hitzestabiler Amylase. Arch. Anım. Nutr., 37: 455 .

Chesson, A., 1987. Supplementary enzymes to improve the utilisation of pig and poultry diets. In: W. Haresign and D.J.A. Cole (Editors), Recent Advances in Animal Nutrition. Butterworths, London, pp. 71-89.

Dierick, N.A., 1989. Biotechnology aids to improve feed and feed digestion: enzymes and fermentation. Arch. Anim. Nutr., 39: 241-261.

DLG, 1991. DLG-Futterwerttabellen-Schweine. DLG-Verlag, Frankfurt am Main, pp. 13-15.

Englyst, H.N. and Hudson, G.J., 1987. Colorimetric method for routine measurement of dietary fibre as non-starch polysaccharides. A comparison with gas-liquid chromatography. Food Chem., 24; 63-76.

Graham, H., Hesselman, K., Jonsson, E. and Åman, P., 1986. Influence of $\beta$-glucanase supplementation on digestion of a barley based diet in the pig gastro-intestinal tract. Nutr. Rep. Int., 34: 1089-1096.

Graham, H., Löwgren, W., Pettersson, D. and Åman, P., 1988. Effect of enzyme supplementation on digestion of a barley/pollard-based pig diet. Nutr. Rep. Int., 38: 1073-1079.

Graham, H., Fadel, J.G., Newman, C.W. and Newman, R.K., 1989. Effect of pelleting and $\beta$ glucanase supplementation on the ileal and whole-tract digestibility of a barley-based diet in the pig. J. Anim. Sci., 67: 1293-1298.

Hampson, D.J. and Kidder, D.E., 1986. Influence of creep feeding and weaning on brush border enzyme activities in the piglet small intestine. Res. Vet. Sci., 40: 24-31.

Inborr, J., Bedford, M.R., Patience, J.F. and Classen, H.L., 1991. The influence of supplementary feed enzymes on nutrient disappearance and digesta characteristics in the GI-tract of early weaned pigs. Proc. Vth Int. Symp. on Digestive Physiology in Pigs, Wageningen, The Netherlands, 24-26 April. Pudoc, Wageningen, EAAP Publ., No. 54, 401-405.

Inborr, J. and Ogle, R.B., 1988. Effect of enzyme treatment of piglet feeds on performance and post-weaning diarrhoea. Swedish J. Agric. Res., 18: 129-133.

Lindemann, M.D., Cornelius, S.G., El Kandelgy, S.M., Moser, R.L. and Pettigrew, J.E., 1986. Effect of age, weaning and diet on digestive enzyme levels in the piglet. J. Anim. Sci., 62: 1298-1307.

Low, A.G., 1985. The role of dietary fibre in digestion, absorption and metabolism. In: Proc. 3rd Internatl. Seminar on Digestive Physiology in the Pig, National Institute of Animal Sci- 
ence, Copenhagen, Denmark. Landhusholdningsselskabets forlag, Copenhagen, Beretning fra Statens Husdyrbrugsforsog, No. 580, 157-179.

Markström, B., Pettersson, D. and Hesselman, K., 1985. $\beta$-glukanastillsats till grov- och finmalet korn - ett smältbarhetsförsök med smågrisar. Swedish University of Agricultural Sciences, Department of Animal Nutrition and Management, Report 149, 15 pp.

McCleary, B.V. and Codd, R., 1991. Measurement of (1-3), (1-4)- $\beta$-D-glucan in barley and oats: A streamlined enzymic procedure. J. Sci. Food Agric., 55: 303-312.

McCracken, K.J., 1984. Effect of diet composition on digestive development of early-weaned pigs. Proc. Nutr. Soc., 43: 109A (abstract).

McCracken, K.J. and Kelly, D., 1984. Effect of diet and post-weaning food intake on digestive development of early-weaned pigs. Proc. Nutr. Soc., 43: 110A (abstract).

Meyer, J.H., Gu, Y., Elashoff, J., Reedy, T., Dressman, J. and Amidon, G., 1986. Effects of viscosity and fluid outflow on postcibal gastric emptying of solids. Am. J. Physiol., 250: G161-G164.

Mourot, J. and Corring, T., 1979. Adaption of the lipase-colipase system to dietary lipid content in pig pancreatic tissue. Ann. Biol. Anim. Biochem. Biophys., 19 (1A): 119-124.

Okai, D.B., Aherne, F.X. and Hardin, R.T., 1976. Effects of creep and starter composition on feed intake and performance of young pigs. Can. J. Anim. Sci., 56: 573-586.

Owsley, W.F., Orr, Jr., D.E. and Tribble, L.F., 1986. Effects of age and diet on the development of the pancreas and the synthesis and secretion of pancreatic enzymes in the young pig. $J$. Anim. Sci., 63: 497-504.

Potkins, Z.V., Lawrence, T.L.J. and Thomlinson, J.R., 1991. Effects of structural and non-structural polysaccharides in the diet of the growing pig on gastric emptying rate and rate of passage of digesta to the terminal ileum and through the total gastrointestinal tract. Br. J. Nutr., 65: 391-413.

Sachs, L., 1992. Angewandte Statistik. 7. Auflage, Springer Verlag, Berlin, 848 pp.

Szabo, J., Ribiczeyne-Szabo, P. and Rafai, P., 1976. A pancreas-hidrolazok aktivitasanak vizsgalata kulonbozo kornyezeti homesekleten tartott sertesekben. Magyar Allatorvosok Lapja, 31: 125-128.

Thomke, S., Rundgren, M. and Hesselman, K., 1980. The effect of feeding high-viscosity barley to pigs. 31st Annual Meeting of EAAP, Munich. Commission on Animal Nutrition, p. 5 (Abstract).

VDLUFA, 1975. Methodenbuch VDLUFA, Band III. Methode 6.1.1., Darmstadt, Germany, pp. 1-4.

Vervaeke, I.J., Graham, H., Dierick, N.A., Demeyer, D.I. and Decuypere, J.A., 1991. Chemical analysis of cell walls and energy digestibility in growing pigs. Anim. Feed Sci. Technol., 32: $55-61$.

White, W.B., Bird, H.R., Sunde, M.L., Prentice, N., Burger, W.C. and Marlett, J.A., 1981. The viscosity interaction of barley beta-glucan with Trichoderma viride cellulase in the chick intestine. Poult. Sci., 60: 1043-1048. 



\section{Gastrointestinal parameters influencing performance of pigs fed enzyme-supplemented barley-based feeds.}

\section{BY JOHAN INBORR ${ }^{1}$}

Finnfeeds International Ltd., Market House, Ailesbury Court, High Street, Marlborough, Wiltshire SN8 1AA, United Kingdom.

${ }^{1}$ Present address: Svenska Foder Ab, Kinnegatan 23, Box 673, S-53116 Lidköping, Sweden 


\section{Abstract}

Forty early-weaned pigs were housed individually in metabolism cages and fed diets based on either a hulled (var. Arra) or hulless (var. Condor) barley with or without added $\beta$-glucanase for a 21-day period during which feed intake and live weight gain were monitored. At the end of the experiment the pigs were sacrificed and the entire gastrointestinal tract removed and divided into nine sections (stomach, four small intestinal sections of equal length, caecum, ascending and descending colon and rectum). Digesta from each of the GI segments was analysed for viscosity, dry matter and nutrient digestibility using chromic oxide as an indigestible marker. Addition of enzyme increased live weight gain $(P=0.074)$ and improved feed utilisation $(P=0.058)$ of the pigs. Enzyme supplementation significantly $(\mathrm{P}<0.0001)$ increased the digestibility of $\beta$ glucans and reduced digesta viscosity in the stomach and three proximal quarters of the small intestine $(\mathrm{P}<\mathbf{0 . 0 3})$. Furthermore, the activity of digestive enzymes was reduced $(P<0.08)$ due to addition of the enzyme without affecting dry matter, starch, nitrogen or energy digestibility. It appears that through enzyme supplementation more optimal conditions for digestion of the nutrients were created and endogenous losses reduced, which, in turn, resulted in improved performance of the pigs.

INDEXING KEY WORDS: pig, enzyme supplementation, $\beta$-glucanase, barley, nutrient digestibility, digesta viscosity, digestive enzymes. 
Pigs like other monogastric animals do not produce enzymes capable of digesting fibre. Indeed dietary fibre components can interfere with the digestion and production of digestive enzymes (Graham, 1988; Ikegami et al., 1990). Dietary fibre is usually defined as non-starch polysaccharides and lignin (Low, 1985) and consists of a large number of complex carbohydrates with different chemical and physical properties. In barley, the main dietary fibre component are cellulose and the mixed-linked $\beta$-glucans (Åman \& Graham, 1987), the concentration and solubility of which can change with both cultivar and conditions during the growing and harvest seasons (Hesselman \& Thomke, 1982). In poultry, soluble $\beta$-glucans form a viscous environment in the intestinal lumen (White et al., 1981), which impaires optimal nutrient digestibility and performance of the birds (Hesselman, 1983). Similar effects have not been observed in pigs. However, replacing maize or wheat with barley in rations for pigs has sometimes resulted in poorer growth and feed utilisation (McConnell et al., 1975; Lawrence, 1973) and reduced nutrient digestibility (Lawrence, 1972; Furuya and Kaji, 1991), indicating some anti-nutritive effects of the barleys employed. Furthermore, supplementation of barley-based diets with fibre degrading enzymes has been reported to improve pig performance and nutrient ileal (Graham et al., 1988; Bedford et al., 1992; Inborr et al., 1993) and faecal digestibility (Thomke et al., 1980; Markström et al., 1985), although not consistently (Graham et al., 1986).

Viscous polysaccharides may exert their anti-nutritive activity by changing the rate of gastric emptying (Meyer et al., 1986; Rainbird \& Low, 1986) and feed transit time (Cherbut et al., 1990). They have also been shown to influence the amount of digestive secretions (Ikegami et al., 1990). The fact that addition of $\beta$-glucanase to diets based on barley improves both nutrient digestibility and performance of pigs indicates that the enzyme is capable of removing some of the anti-nutritive activities of the mixed-linked $\beta$-glucans. In broiler chickens, reduced intestinal viscosity following enzyme supplementation of wheat and barley-based diets has been found to be highly correlated with improved performance (Bedford \& Classen, 1992; Inborr et al., 1993). Similar relationships have not been found in pigs fed enzyme-supplemented barley-based feeds (Bedford et al., 1992) and it is possible that other mechanisms are of greater importance.

This investigation was undertaken to study the effect of $\beta$-glucanase supplementation of barley-based diets on pig performance and some gastrointestinal parameters relating to the 
digestive processes. The aim of the study was to investigate the relationships between the physiological parameters and pig performance in order to explain some of the mechanisms behind the enzyme-induced performance responses.

\section{EXPERIMENTAL}

\section{Animals and experimental design}

A total of 40 pigs (alternating DL $\times$ LW) weaned at about four weeks of age with an average live weight of $9.5 \mathrm{~kg}$ were divided into five blocks of eight and placed into individual metabolism cages and assigned to one of four dietary treatments based on live weight, sex and litter origin. The pigs of each block were fed the experimental diets for 21days. There were two treatment replicates per block with each replicate consisting of four littermate pigs. The experimental diets were based on one of two barley cultivars either with or without added $\beta$-glucanase to give a $2 \times 2$ factorial design.

\section{Diets and feeding}

The basal diets were based on barley, soybean and fish meal (Table 1). There were two barley cultivars, one hulless (var. Condor, Canadian Wheat Board, Winnipeg, Canada) with relatively high $\beta$-glucan content and low crude fibre, and one hulled (var. Arra, Valtion Viljavarasto, Ylivieska, Finland) with relatively low $\beta$-glucan and high crude fibre content (Table 1). The two basal diets were supplemented with a Trichoderma longibrachiatum cellulase preparation (Genencor International Ltd., Helsinki, Finland) with high $\beta$-glucanase activity. The diets were fed semi ad libitum in mash form during the entire experimental period with water freely available. 
Table 1. Composition of the experimental diets and the two barleys $(\mathrm{g} / \mathrm{kg})$

\begin{tabular}{lllll}
\hline Diet/barley... & A & C & Arra & Condor \\
\hline
\end{tabular}

\section{$\underline{\text { Ingredients }}$}

Arra barley

Condor barley

755.4

Soybean meal $(48 \% \mathrm{CP})$

150

150

Fish meal

40

40

Soya oil

20

20

Limestone

13

13

Dicalcium phosphate

10

10

Salt

3

3

$\mathrm{HCl}$-Lysine

2.6

2.6

Vitamin/mineral mix $^{1}$

Chromic oxide (marker)

4

4

2

2

$\beta$-glucanase ${ }^{2}$

$-/ 0.25$

$-/ 0.25$

\section{Nutrients (analysed)}

Protein (Nx6.25)

$\mathrm{HCl}$-fat

63

65

30

22

Ash

64

63

45

49

Starch

391

452

513

583

Total $\beta$-glucan

20

34

26

48

Crude fibre

178

142

61

21

Total NSP

195

183

\footnotetext{
${ }^{1}$ Provided the following (mg/kg diet): retinol 5.5, cholecalciferol $0.05, \alpha$-tocopherol 85 , menadione 2.4 , thiamin 2.4 , riboflavine 4.8 , pyridoxine 3.6 , pantothenic acid 12 , nicotinic acid 24, biotin 0.24 , cyanocobalamin $0.024, \mathrm{Fe}\left(\mathrm{FeSO}_{4} \bullet 7 \mathrm{H}_{2} \mathrm{O}\right) 200, \mathrm{Zn}(\mathrm{ZnO}) 200, \mathrm{Mn}$ $(\mathrm{MnO}) 55.4, \mathrm{Cu}\left(\mathrm{CuSO}_{4} \bullet 5 \mathrm{H}_{2} \mathrm{O}\right)$ 165, I (KI) 0.3, $\mathrm{Se}\left(\mathrm{Na}_{2} \mathrm{SeO}_{3}\right)$ 0.3.

${ }^{2}$ added at the expense of barley in diets $\mathrm{A}+$ and $\mathrm{C}+$ (see section Diets and feeding)
} 
Digesta sample collection

On day 21 the pigs were sacrificed by means of an overdose of sodium pentobarbiturate and bled. The digestive tract was rapidly removed and divided into the following sections by ligatures: stomach (Sto), four small intestinal sections of equal length (SI1, SI2 SI3 and SI4), caecum (Cae), ascending (Co1) and descending (Co2) colon and rectum ( $\operatorname{Rec})$. The total contents of each section was carefully collected and weighed. Aliquots of suitable size were taken immediately after collection for the viscosity measurements. The other samples were frozen immediately and stored at $-20{ }^{\circ} \mathrm{C}$ until needed for further analysis.

Chemical analyses and measurements

All analyses were made in duplicate. $\mathrm{Cr}_{2} \mathrm{O}_{3}$, nitrogen and digesta viscosity determinations were performed on wet material. All other analyses were carried out on freeze-dried materials. Dry matter content of feed and digesta was determined by drying at $105{ }^{\circ} \mathrm{C}$ to constant weight. Protein ( $\mathrm{N}$ 6.25) was determined by the Kjeldahl method using a KjellFoss 16200 autoanalyser and energy by an IKA calorimeter C 400 (Janke \& Kunthel KG IKA-Werk, Germany) using benzoic acid (BCS-CRM No. 190n BAS) for calibration. Ash was analysed according to AOAC (Association of Official Analytical Chemists, 1975), while fat (hydrochloric acid-fat) was extracted with diethyl ether after acid-hydrolysis (Stoldt, 1957). $\mathrm{Cr}_{2} \mathrm{O}_{3}$ was determined using the method of Schürch et al. (1950). Total $\beta$-glucan was determined by the enzymatic methods of McCleary \& Glennie-Holmes (1985) and starch was analysed by modification of the enzymatic method of Bach Knudsen et al. (1987). Starch was gelatinised and quantitatively removed by incubation $\left(100{ }^{\circ} \mathrm{C}, 60 \mathrm{~min} ., 60{ }^{\circ} \mathrm{C}, 16 \mathrm{~h}\right)$ with thermostable $\alpha$-amylase (EC 3.2.1.1. Termamyl ${ }^{\circledR}$, Novo Nordisk A/S, Denmark), which at $100^{\circ} \mathrm{C}$ was $\beta$-glucanase-free, and a $\beta$-glucanase-free amyloglucosidase (EC 3.2.1.3., Cat No. 1060 074, Boehringer Mannheim, GmbH, Mannheim, Germany). The resulting glucose monomers were quantified with glucose oxidase reagent (EC 1.1.3.4., Cat No. 124001, Boehringer Mannheim $\mathrm{GmbH}$ ).

Digesta viscosity was measured in the supernatant after centrifugation of the digesta samples at 13,000 rpm for 3 minutes (Biofuge A; Heareus Sepatech GmbH, Germany) using 
a Brookfield viscometer (model DV-II+; Brookfield Engineering Laboratories Inc., Stoughton, MA, USA) operated at room temperature.

Pigs were weighed on days $1,7,14$ and 21 and the amount of feed consumed recorded at the end of each week.

Enzyme activity analyses

$\beta$-glucanase (EC 3.2.1.6; endo- $\beta-(1,3)(1,4)$-glucanase) activity measurements of the feed and stomach samples were carried out viscosimetrically using $1.0 \%$ barley $\beta$-glucan (Biocon Biochemicals Ltd., Cork, Ireland) in McIlvaine's buffer as substrate by the method described by Bathgate (1979) with minor modifications. This method measures the reduction in substrate viscosity and enzyme activity is expressed as the increase in reciprocal viscosity (IRV).

$1 \%(\mathrm{w} / \mathrm{w}) \beta$-glucan substrate was prepared by solubilising $1 \mathrm{~g}$ of barley $\beta$-glucan (Biocon Biochemicals Ltd., Cork, Ireland) in $6 \mathrm{ml}$ of ethanol in a tared beaker. $10 \mathrm{ml}$ of $0.5 \mathrm{M}$ sodium acetate buffer ( $\mathrm{pH} 4.0)$ was added and then distilled water to a final volume of 100 $\mathrm{ml}$. The $\beta$-glucan solution was standardised to initial reciprocal specific viscosity of 0.13 by adjusting the $\beta$-glucan:buffer ratio. In the measurements the volume of the $\beta$-glucan substrate varied between 5.3 and $5.5 \mathrm{ml}$ and that of the enzyme solution between 2.0 and $2.2 \mathrm{ml}$. The total volume of the substrate/enzyme solution was adjusted to $7.5 \mathrm{ml}$ before each measurement.

After enzyme addition, four to six flow times were determined over a 30 minute time period in an Ostwald capillary viscometer (Model No. II, 75-100 s), immersed in a water bath set at $30^{\circ} \mathrm{C}$. The flow times were used to calculate the reciprocal specific viscosities, using the equation;

$$
1 / \eta_{\text {sp }}=\mathrm{dT}_{0}
$$

where $1 / \eta_{\mathrm{sp}}$ is the reciprocal specific viscosity, $\mathrm{dT}_{0}$ the flow time of the buffer and $\mathrm{dT}_{\mathrm{S}}$ the flow time of the substrate-enzyme solution. 
$\beta$-glucanase activity is expressed as increase in reciprocal specific viscosity (IRV) and calculated using the equation;

$$
\mathrm{k} * \mathrm{D}
$$

$\beta$-glucanase, IRV Units/g $=$

\section{V}

where $\mathrm{k}$ is the slope of the curve plotted from the reciprocal specific viscosity versus hydrolysis time (minutes), D is the total dilution factor and V sample volume. One IRV unit is defined as the change of one $\left(1 / \eta_{\mathrm{sp}}\right) \min ^{-1}$. Each measurement was carried out in duplicates.

Enzyme activity analyses of the samples obtained from the three proximal quarters of the small intestine were performed on lyophilized material, which was extracted with $1 \mathrm{mM} \mathrm{HCl}$ (50 mg lyophilized digesta in $1 \mathrm{ml} \mathrm{HCl}$ ) for one hour at $4^{\circ} \mathrm{C}$ followed by centrifugation $(3000 \times \mathrm{g})$. The supernatants were then collected for activity analyses.

Trypsin (EC 3.4.21.4) activity was determined using Benzoyl-DL-arginine-p-nitroanilide (DL-BAPA) as substrate according to Erlanger et al., (1961) with minor modifications. Aliquots of $450 \mu \mathrm{l}$ of substrate were incubated at $37{ }^{\circ} \mathrm{C}$ and mixed with $50 \mu \mathrm{l}$ extract before transferred to a cuvette equlibrated at $37{ }^{\circ} \mathrm{C}$ in a Milton Roy (spectronic 1201) spectrophotometer. Absorbance was measured every 20 seconds for 100 seconds and enzyme activity was calculated from the initial velocity of the reaction. Chymotrypsin (EC 3.4.21.1) was determined according to Erlanger et al. (1966) and Boisen et al. (1981) using glutaryl-1phenylalanin-p-nitroanilid (GPNA) as substrate.

Amylase (EC 3.2.1.1) activity was determined using the Phadebas ${ }^{\circledR}$ Amylase Test kit (Pharmacia Diagnostics, Uppsala, Sweden) and lipase (EC 3.1.1.3) by a pH-stat titration method using tributyrine as substrate according to Erlandsson-Albertsson et al., (1987). 15 $\mathrm{ml}$ of buffer containing $1 \mathrm{mM}$ Tris- $\mathrm{HCl}$ at $\mathrm{pH} 7.0,1 \mathrm{mM} \mathrm{CaCl}, 150 \mathrm{mM} \mathrm{NaCl}$ and $4 \mathrm{mM}$ sodium taurodeoxycholate were mixed with $500 \mu \mathrm{l}$ tributyrin and 100-400 $\mu \mathrm{l}$ of extract.

Enzyme activities are expressed as units (micromoles substrate hydrolysed per minute per $\mathrm{ml})$ per gram sample dry matter and and per total segment dry matter $(\mathrm{U} / \mathrm{g} \times \mathrm{g}$ segment dry matter). 
Calculations and statistical analyses

All data were subjected to ANOVA according to the GLM procedure (Statistical Analysis System Institute, 1982). Where relevant, means were separated by orthogonal contrasts. Main effects, or in the event of interactions, single effects are displayed. When analysing the performance data the barley $\times$ enzyme interaction was found non-significant and, therefore, excluded from the model. Data presented graphically were analysed by linear regression analysis using the linear and quadratic coefficients of gut segment. Nutrient digestibilities were calculated relative to the indigestible marker $\left(\mathrm{Cr}_{2} \mathrm{O}_{3}\right)$ content:

$$
\text { Digestibility of } \mathrm{X}=1-\frac{\mathrm{Cr}_{2} \mathrm{O}_{3 \text { (die) }} \times \mathrm{X}_{\text {(digesta) }}}{\mathrm{Cr}_{2} \mathrm{O}_{3 \text { (digesta) }} \times \mathrm{X}_{\text {(die) }}}
$$

where $\mathrm{X}$ is the nutrient in question. $\mathrm{X}_{\text {(diet) }}$ and $\mathrm{X}_{\text {(digesta) }}$ are concentrations of specific nutrients in the diet and digesta taken from the different sections of the GI tract. Due to the small samples obtained in the two most proximal sections of the small intestine these samples were pooled when possible. When calculating starch digestibility it was assumed that free glucose in the digesta was derived from starch.

\section{RESULTS}

\section{Chemical composition of the barleys and experimental diets}

Diets based on the Arra barley contained less starch and $\beta$-glucans than those based on Condor barley (Table 1). This reflected the concentrations of these two constituents in the barleys. The content of protein, fat and ash was equal in all experimental diets.

\section{Pig performance}

Feed intake was not influenced, whereas live weight gain $(\mathrm{P}=0.074)$ and feed conversion ratio $(P=0.058)$ were improved by the enzyme treatment (Table 2$)$. Pigs fed the diets based on Arra barley tended to have lower body weight gain $(P=0.16)$ than those fed Condor. 
Table 2. Live weight gain $(\mathrm{g} / \mathrm{d})$, feed intake $(\mathrm{g} / \mathrm{d})$ and feed conversion ratio of the pigs during the three-week period.

\begin{tabular}{|c|c|c|c|c|c|c|c|}
\hline \multirow[t]{2}{*}{ Diet... } & \multirow[t]{2}{*}{ A- } & \multirow[t]{2}{*}{$A+$} & \multirow[t]{2}{*}{ C. } & \multirow[t]{2}{*}{$\mathrm{C}+$} & \multicolumn{2}{|c|}{ P-values for main effects } & \multirow{2}{*}{$\begin{array}{l}\text { Pooled } \\
\text { variance }\end{array}$} \\
\hline & & & & & barley & enzyme & \\
\hline Live weight gain & 200 & 208 & 223 & 229 & 0.160 & 0.074 & 0.022 \\
\hline Feed intake & 340 & 339 & 350 & 337 & 0.675 & 0.340 & 0.028 \\
\hline Feed conversion & 1.708 & 1.646 & 1.597 & 1.516 & 0.227 & 0.058 & 0.146 \\
\hline
\end{tabular}




\section{Digestibility of nutrients}

$\beta$-glucan digestibility was significantly higher in the diets containing the added $\beta$-glucanase (Figure 1) but there was no significant effect of the enzyme on dry matter or starch digestibility (Figures 2 and 3). Dry matter digestibility of the Condor-based diets was higher $(\mathrm{P}<0.001)$ than of those based on Arra, whereas regarding starch digestibility the order was reversed between the barleys $(\mathrm{P}=0.154)$. Protein digestibility tended to be higher for the enzyme-supplemented diets $(\mathrm{P}=0.117)$ with the greatest improvement due to enzyme supplementation observed in SI3 (Figure 4).

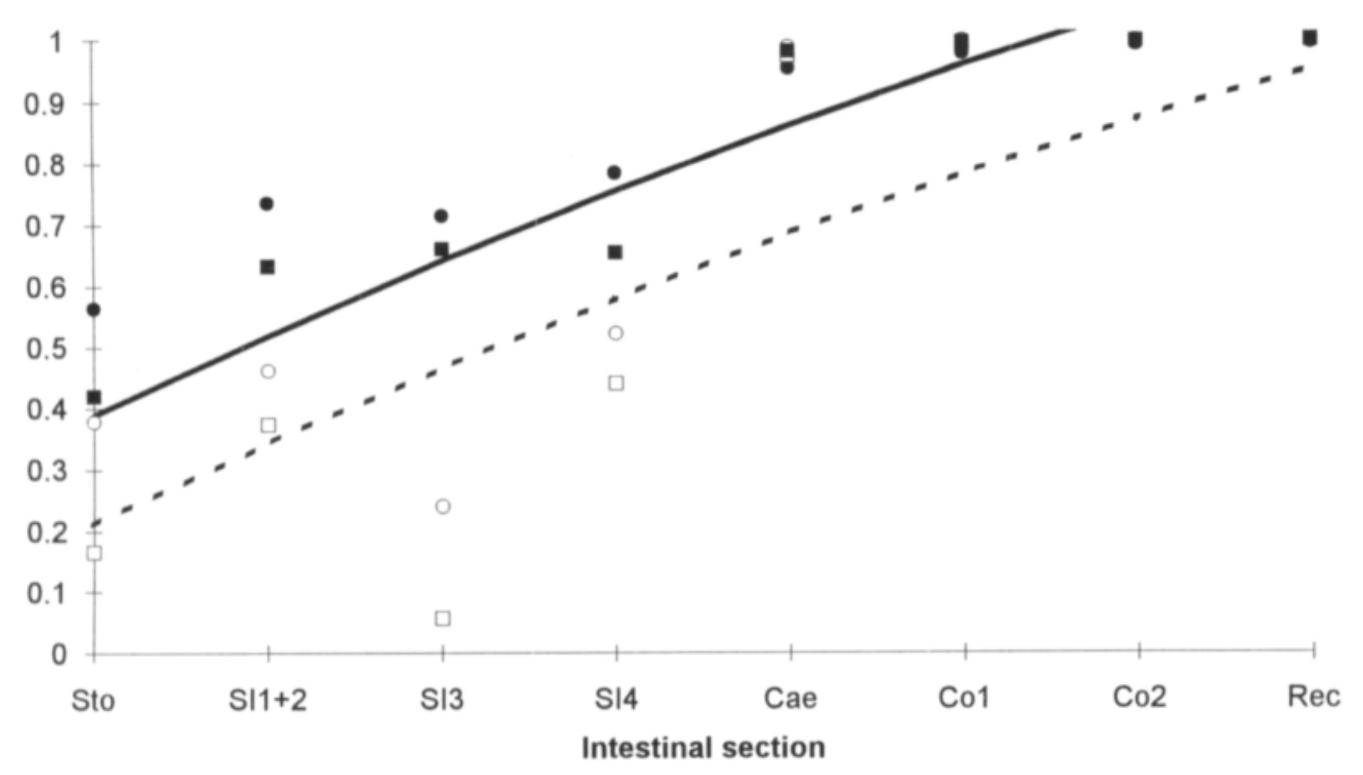

Figure 1. $\beta$-glucan digestibility in the stomach (Sto), proximal two $(\mathrm{SI} 1+2)$, third (SI3) and fourth (SI4) quarters of the small intestine, caecum (Cae), ascending colon (Co1), descending colon $(\mathrm{Co} 2)$ and rectum $(\mathrm{Rec})$ of pigs fed Arra barley without $(\mathrm{O})$ or with $(\bullet)$, or Condor barley without $(\square)$ or with ( $\square)$ added $\beta$-glucanase. No significant barley $\times$ enzyme interaction observed. Regression lines shown for barley with (-) and without (----) enzyme supplementation.

Regression $=0.248(0.051)+0.144(0.023) \times$ segment $-0.004(0.003) \times$ segment $\times$ segment $+0.1636(0.033) \times$ enzyme inclusion level. Model P-value $<0.0001\left(\mathrm{r}^{2}=0.643\right)$. 


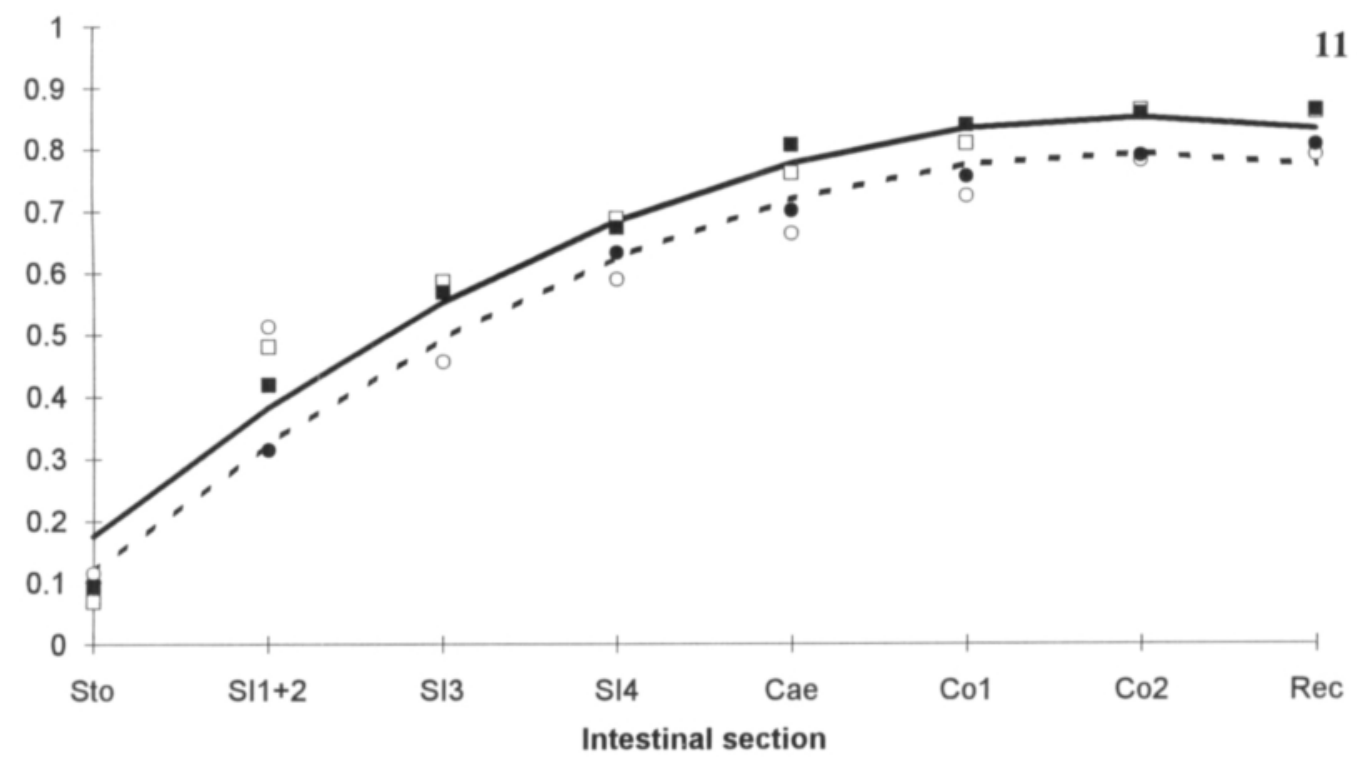

Figure 2. Dry matter digestibility in the stomach (Sto), proximal two (SI1+2), third (SI3) and fourth (SI4) quarters of the small intestine, caecum (Cae), ascending colon (Co1), descending colon (Co2) and rectum (Rec) of pigs fed Arra barley without (O) or with ( ), or Condor barley without $(\square)$ or with ( $\boldsymbol{\square})$ added $\beta$-glucanase. No significant effect of enzyme observed. Regression lines are shown for Arra (----) and Condor (-).

Regression $=-0.070(0.025)+0.264(0.012) \times$ segment $-0.019(0.001) \times$ segment $\times$ segment $+0.058(0.012) \times$ barley. Model P-value $=0.0001\left(\mathrm{r}^{2}=0.844\right)$.

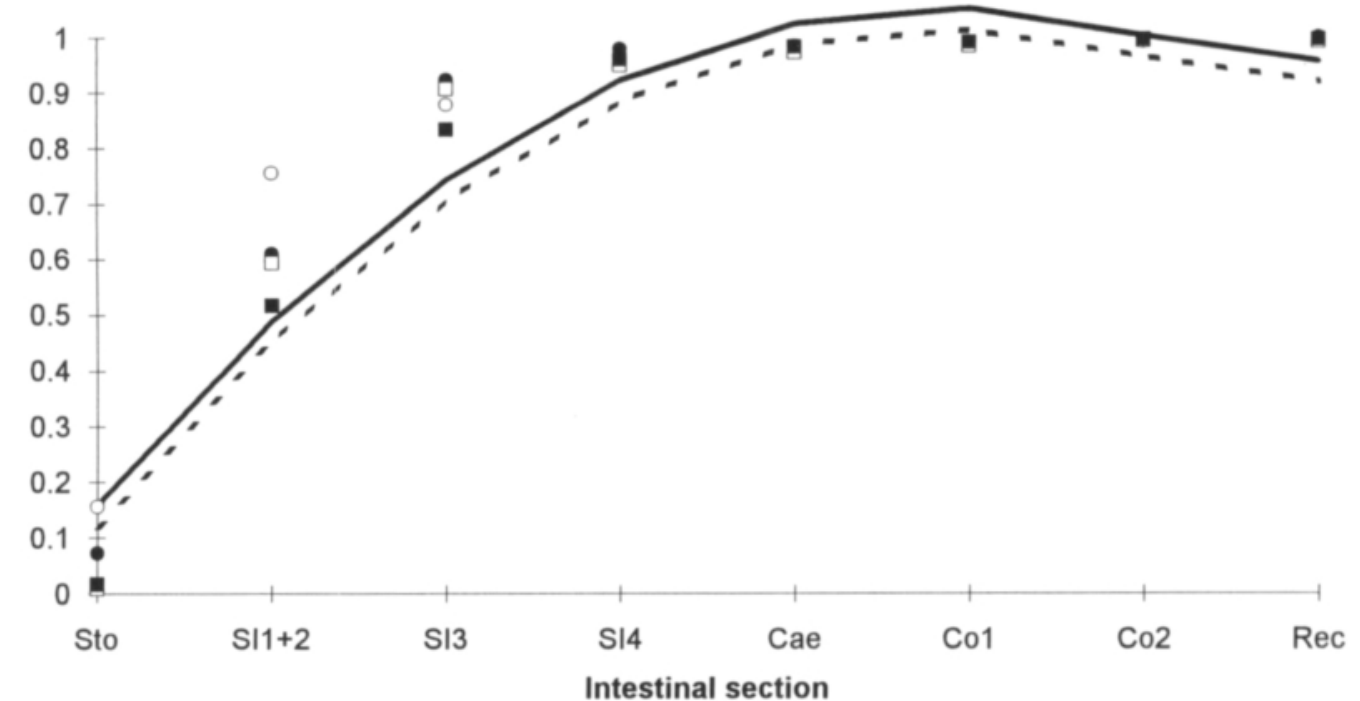

Figure 3. Starch digestibility in the stomach (Sto), proximal two (SI1+2), third (SI3) and fourth (SI4) quarters of the small intestine, caecum (Cae), ascending colon (Co1), descending colon (Co2) and rectum (Rec) of pigs fed Arra barley without $(\mathrm{O})$ or with $(\boldsymbol{O})$, or Condor barley without $(\square)$ or with ( $\mathbf{\square})$ added $\beta$-glucanase. No significant effect of enzyme observed. Regression lines shown for Arra (-) and Condor (----).

Regression $=-0.249(0.036)+0.445(0.017) \times$ segment $-0.038(0.002) \times$ segment $\times$ segment $+0.034(0.024) \times$ barley. Model P-value $=0.154\left(\mathrm{r}^{2}=0.820\right)$. 


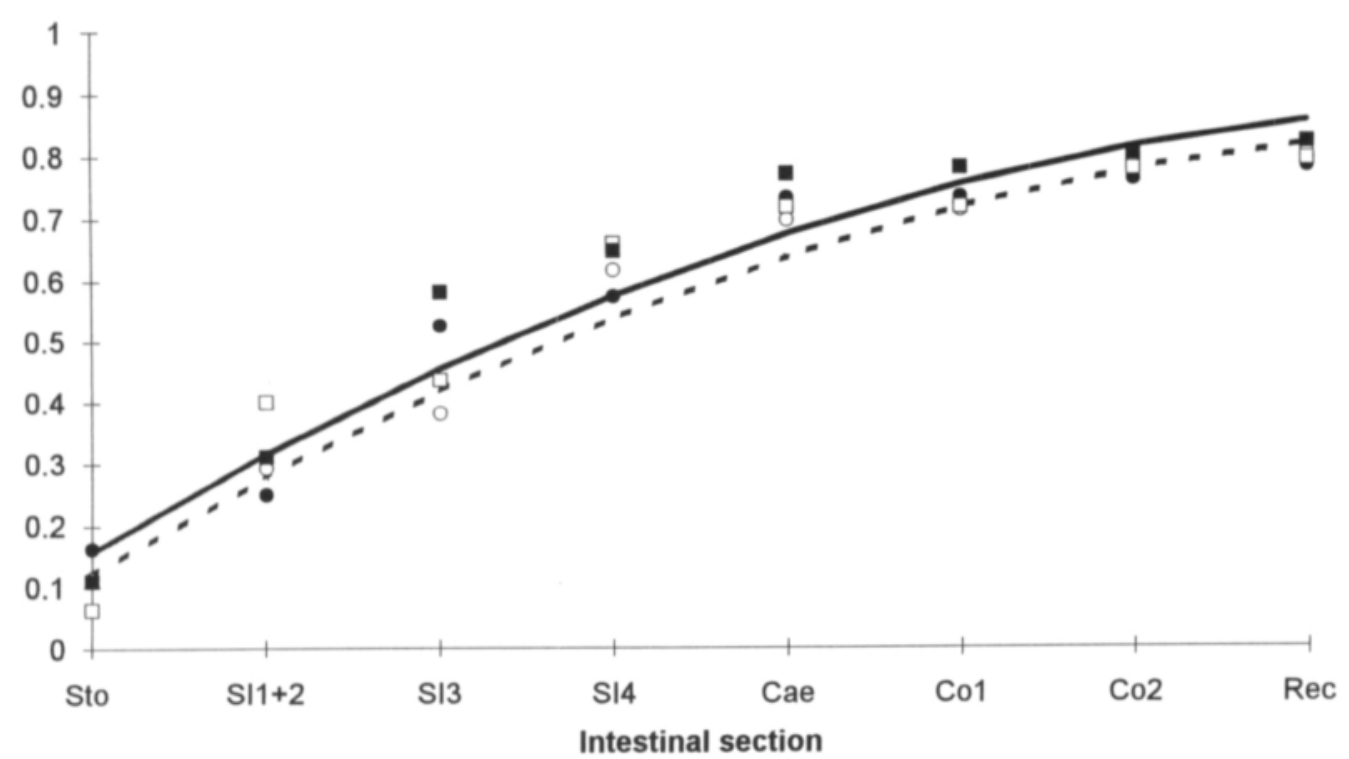

Figure 4. Nitrogen digestibility in the stomach (Sto), proximal two (SI1+2), third (SI3) and fourth (SI4) quarters of the small intestine, caecum (Cae), ascending colon (Co1), descending colon $(\mathrm{Co} 2)$ and rectum $(\mathrm{Rec})$ of pigs fed Arra barley without $(\mathrm{O})$ or with $(\boldsymbol{\bullet})$, or Condor barley without $(\square)$ or with ( $\square)$ added $\beta$-glucanase. No significant barley $\times$ enzyme interaction observed. Regression lines shown for barley with (-) and without (----) enzyme supplementation. Regression $=-0.059(0.035)+0.189(0.014) \times$ segment $0.010(0.001) \times$ segment $\times$ segment $+0.0285(0.023) \times$ enzyme inclusion level. Model P-value $=0.117\left(\mathrm{r}^{2}=0.784\right)$.

Energy digestibility in the last. quarter of the small intestine (segment SI4) and rectum was not influenced by the enzyme treatments, whereas the values for Condor were significantly higher $(\mathrm{P}=0.017$ in SI4 and $\mathrm{P}=0.001$ in rectum) than those for Arra (Table 3).

\section{Enzyme activities in feed and digesta}

Endogenous $\beta$-glucanase activity of the control diet based on Arra was higher than that of the diet based on Condor (Table 4). Stomach digesta $\beta$-glucanase activity of the enzymesupplemented diets was approximately $25 \%$ of that in the diets when expressed on a fresh material basis, which reflected the dilution of the feed by water and gastric secretions. 
Table 3. Digestibility of energy in segment SI4 and rectum of pigs fed either Arra or Condor barley with and without supplementary $\beta$-glucanase.

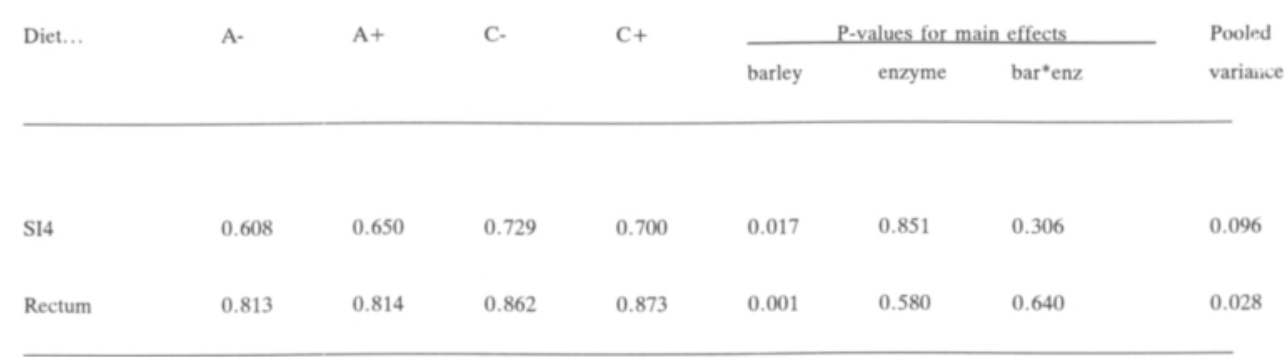


Table 4. $\beta$-glucanase activity of the diets and stomach digesta samples, $\mathrm{mU} / \mathrm{g}$ fresh weight

\begin{tabular}{lccll}
\hline Diet... & A- & A & C- & C + \\
\hline Feed & $11.5(3.5)^{1}$ & $95(2.0)$ & $2(0.0)$ & $89(0.5)$ \\
$\mathrm{n}$ & 2 & 2 & 2 & 2 \\
Digesta & $1.5(0.6)$ & $24(6.6)$ & $1.2(0.6)$ & $23.7(9.4)$ \\
$\mathrm{n}$ & 5 & 8 & 8 & 5 \\
\hline
\end{tabular}

${ }^{1}$ Values are means (standard deviation)

When expressed on a sample dry matter basis digestive enzyme activities in the three proximal quarters of the small intestine of pigs fed the enzyme-supplemented diets were significantly lower $(\mathrm{P}<0.08)$ than in pigs fed the control diets (Table 5). There was a significant barley $\times$ enzyme interaction $(\mathrm{P}=0.002)$ for chymotrypsin. This showed that enzyme supplementation of the Condor-based diet significantly reduced chymotrypsin activity but tended to have the opposite effect on the diet based on Arra (Table 6), whereas feeding the two barleys without enzyme resulted in significantly higher chymotrypsin levels in pigs fed the Condor compared to Arra barley.

Table 6. P-values for the chymotrypsin (mU/g digesta DM) interactions.

\begin{tabular}{llll}
\hline & Enzyme & Barley & Pooled variance \\
\hline Arra & 0.068 & $\cdot$ & 0.085 \\
Condor & 0.015 & $\cdot$ & 0.067 \\
No enzyme &. & 0.023 & 0.071 \\
Enzyme &. & 0.044 & 0.078 \\
\end{tabular}


Table 5. Trypsin, chymotrypsin, lipase and amylase activity in segments $\mathrm{SI} 1+2$ and SI3 of the GI-tract expressed as mU/g digesta DM.

\begin{tabular}{|c|c|c|c|c|c|c|c|c|c|}
\hline \multirow[t]{2}{*}{ Diet... } & \multirow[t]{2}{*}{ A- } & \multirow[t]{2}{*}{ At } & \multirow[t]{2}{*}{ c. } & \multirow[t]{2}{*}{$\mathrm{C}+$} & \multicolumn{4}{|c|}{ P-values for main effects } & \multirow{2}{*}{$\begin{array}{l}\text { Pooled } \\
\text { variance }\end{array}$} \\
\hline & & & & & barley & enzyme & bar*enz & $\operatorname{seg}$ & \\
\hline \multicolumn{10}{|l|}{ Trypsin } \\
\hline $\operatorname{SIl}+2$ & 10.1 & 5.2 & 9.8 & 6.4 & 0.592 & 0.034 & 0.396 & 0.0001 & 6.38 \\
\hline $\mathbf{S 1 3}$ & 10.9 & 15.9 & 15.2 & 13.9 & & & & & \\
\hline \multicolumn{10}{|l|}{ Chymotrypsin } \\
\hline $\mathrm{SI1}+2$ & 0.12 & 0.14 & 0.17 & 0.07 & 0.996 & 0.059 & 0.002 & 0.641 & 0.074 \\
\hline S13 & 0.07 & 0.16 & 0.13 & 0.11 & & & & & \\
\hline \multicolumn{10}{|l|}{ Lipase } \\
\hline $\mathrm{SII}+2$ & 98.6 & 53.5 & 93.0 & 49.3 & 0.653 & 0.077 & 0.689 & 0.791 & 76.6 \\
\hline SI3 & 54.7 & 81.5 & 89.4 & 87.2 & & & & & \\
\hline \multicolumn{10}{|l|}{ Amylase } \\
\hline $\mathrm{SII}+2$ & 1073 & 479 & 659 & 422 & 0.205 & 0.038 & 0.970 & 0.025 & 576 \\
\hline S13 & 920 & 1094 & 973 & 829 & & & & & \\
\hline
\end{tabular}

Table 7. Trypsin, chymotrypsin, lipase and amylase activity in segments $\mathrm{SI1}+2$ and $\mathrm{SI} 3$ of the GI-tract expressed as mU/segment DM.

\begin{tabular}{|c|c|c|c|c|c|c|c|c|c|}
\hline \multirow[t]{2}{*}{ Diet } & \multirow[t]{2}{*}{ A- } & \multirow[t]{2}{*}{ A+ } & \multirow[t]{2}{*}{ C. } & \multirow[t]{2}{*}{$\mathrm{C}+$} & \multicolumn{4}{|c|}{ P-values for main effects } & \multirow{2}{*}{$\begin{array}{l}\text { Pooled } \\
\text { variance }\end{array}$} \\
\hline & & & & & barley & enzyme & bar ${ }^{*}$ enz & seg & \\
\hline \multicolumn{10}{|l|}{ Trypsin } \\
\hline SII +2 & 49 & 15 & 45.2 & 23 & 0.677 & 0.107 & 0.141 & 0.0001 & 52.0 \\
\hline S13 & 106 & 148 & 154 & 116 & & & & & \\
\hline \multicolumn{10}{|l|}{ Chymotrypsin } \\
\hline $\operatorname{SIn}+2$ & 0.54 & 0.40 & 1.04 & 0.39 & 0.374 & 0.087 & 0.047 & 0.005 & 0.76 \\
\hline SI3 & 0.75 & 1.35 & 1.27 & 0.97 & & & & & \\
\hline \multicolumn{10}{|l|}{ Lipase } \\
\hline $\mathrm{SII}+2$ & 501 & 154 & 386 & 240 & 0.606 & 0.197 & 0.979 & 0.001 & 553 \\
\hline S13 & 643 & 751 & 874 & 804 & & & & & \\
\hline \multicolumn{10}{|l|}{ Amylase } \\
\hline SI1 +2 & 5209 & 1479 & 3569 & 2016 & 0.417 & 0.050 & 0.978 & 0.0001 & 3912 \\
\hline S13 & 8290 & 9366 & 8460 & 7388 & & & & & \\
\hline
\end{tabular}


When the enzyme activities were expressed on a total segment dry matter basis, enzyme supplementation significantly $(\mathrm{P}=0.050)$ reduced the amylase activity and tended to reduce the chymotrypsin $(\mathrm{P}=0.087)$ activity (Table 7$)$. There was no effect of barley on any of the enzyme activities. A significant $(P=0.047)$ barley $\times$ enzyme interaction was observed for chymotrypsin. Enzyme supplementation tended to reduce $(\mathrm{P}=0.106)$ chymotrypsin activity in pigs fed the Condor barley (Table 8), whereas there was no effect of the enzyme in the Arra-based diets. With no added enzyme, Condor produced higher chymotrypsin $(\mathrm{P}=0.067)$ activity than Arra. Segment SI3 contained significantly more digestive enzyme activity than segment SI1 +2 .

Table 8. P-values of the barley*enzyme interactions for chymotrypsin when enzyme activities were expressed on a segment dry matter basis.

Barley Enzyme Pooled variance

$\begin{array}{llll}\text { Arra } & \cdot & 0.290 & 0.688 \\ \text { Condor } & \cdot & 0.106 & 0.852 \\ \text { No enzyme } & 0.067 & . & 0.843 \\ \text { Enzyme } & 0.374 & . & 0.661\end{array}$

\section{Digesta viscosity and dry matter content}

Enzyme supplementation significantly $(\mathrm{P}<0.03)$ reduced viscosity in the stomach and the three proximal quarters of the small intestine (Table 9). In the caecum and the descending colon of pigs fed the Condor barley and in the colon of the Arra-fed pigs this relation was reversed but the differences were not significant. Condor barley caused significantly $(\mathrm{P}<0.02)$ higher digesta viscosities in caecum and Co2 than Arra. Dry matter content of the digesta of the pigs fed the enzyme supplemented diets was significantly higher $(\mathrm{P}=0.0003)$ than that of those fed the unsupplemented diets (Figure 5). 


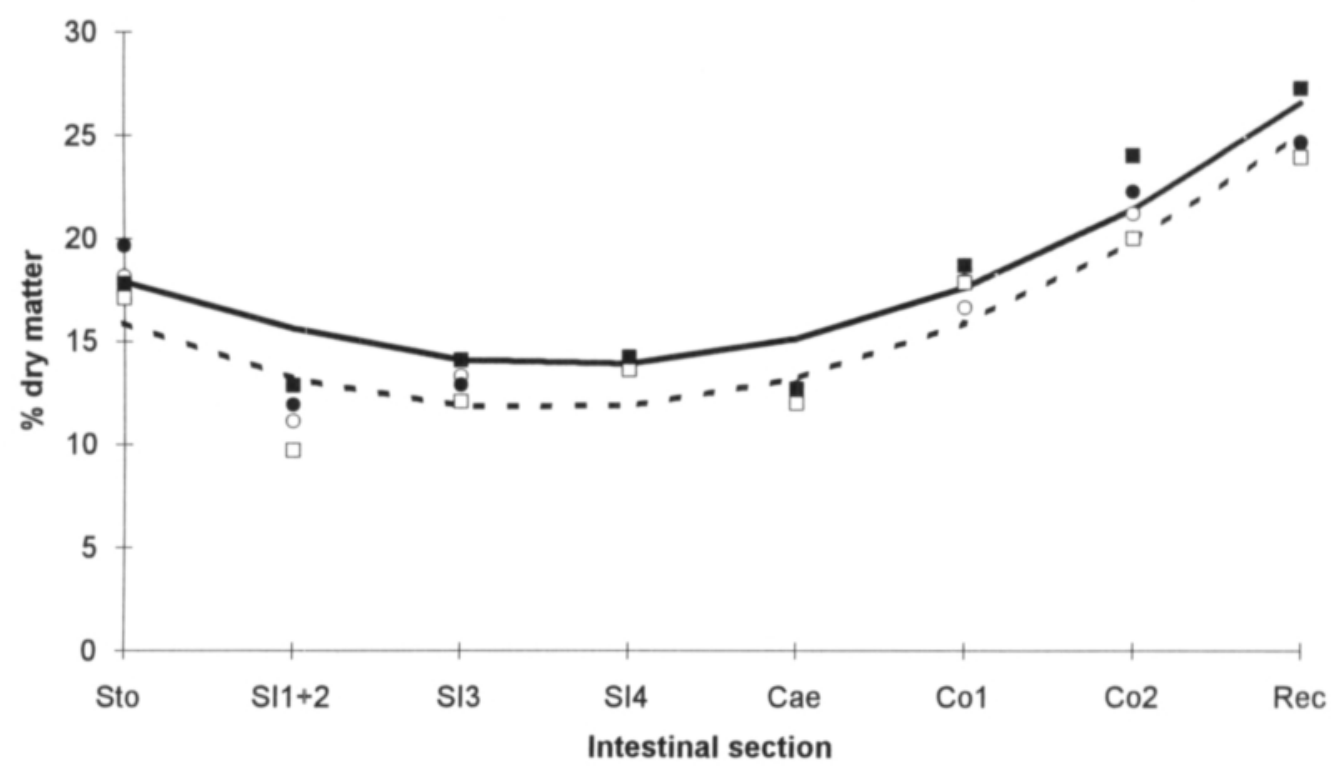

Figure 5. Dry matter content of the stomach (Sto), proximal two (SI1+2), third (SI3) and fourth (SI4) quarters of the small intestine, caecum (Cae), ascending colon (Co1), descending colon $(\mathrm{Co} 2)$ and rectum $(\mathrm{Rec})$ of pigs fed Arra barley without $(\mathrm{O})$ or with $(\boldsymbol{O})$, or Condor barley without $(\square)$ or with $(\square)$ added $\beta$-glucanase. No significant barley $\times$ enzyme interaction observed. Regression lines shown for barley with (-) and without (----) enzyme supplementation.

Regression $=21.8271(0.833)-4.631(0.377) \times$ segment $-0.662(0.041) \times$ segment $\times$ segment $+1.992(0.542) \times$ enzyme inclusion level. Model $\mathrm{P}$-value $=0.0003\left(\mathrm{r}^{2}=0.659\right)$.

\section{DISCUSSION}

$\beta$-glucanase activity of the stomach digesta samples showed full recovery of the added enzyme when expressed on a dry matter basis (data not shown). This is in accordance with results from in-vitro experiments (Inborr and Grönlund, 1993) and those obtained by measuring $\beta$-glucanase activity in the proximal small intestine of broiler chickens fed enzyme-supplemented diets (Inborr and Bedford, 1993). 
Table 9. Digesta viscosity (cP) of the different segments.

\begin{tabular}{|c|c|c|c|c|c|c|c|c|}
\hline \multirow[t]{2}{*}{ Diet... } & \multirow[t]{2}{*}{ A- } & \multirow[t]{2}{*}{$A+$} & \multirow[t]{2}{*}{ C. } & \multirow[t]{2}{*}{$\mathrm{C}+$} & \multicolumn{3}{|c|}{ P-values for main effects } & \multirow{2}{*}{$\begin{array}{l}\text { Poolec } \\
\text { varian }\end{array}$} \\
\hline & & & & & barley & enzyme & bar*enz & \\
\hline Stomach & 1.38 & 1.33 & 1.71 & 1.31 & 0.146 & 0.029 & 0.098 & 0.31 \\
\hline SI1 & 1.48 & 1.43 & 1.93 & 1.32 & 0.384 & 0.021 & 0.065 & 0.36 \\
\hline S12 & 1.93 & 1.74 & 2.94 & 1.77 & 0.123 & 0.004 & 0.057 & 0.48 \\
\hline $\mathrm{SI} 3$ & 2.77 & 2.01 & 3.82 & 2.33 & 0.143 & 0.007 & 0.188 & 0.96 \\
\hline SI4 & 2.55 & 2.44 & 2.94 & 2.52 & 0.773 & 0.306 & 0.556 & 0.68 \\
\hline Caecum & 1.87 & 1.68 & 1.96 & 2.70 & 0.007 & 0.451 & 0.167 & 0.67 \\
\hline Colon1 & 6.15 & 7.93 & 9.85 & 11.11 & 0.143 & 0.337 & 0.685 & 4.99 \\
\hline Colon2 & 7.50 & 10.42 & 14.50 & 13.00 & 0.016 & 0.451 & 0.878 & 3.78 \\
\hline
\end{tabular}


Addition of $\beta$-glucanase to the diets improved live weight gain and feed utilisation of the pigs. This effect is consistent with the results of performance experiments, where $\beta$-glucanase (Thomke et al., 1980) or $\beta$-glucanase-containing enzyme mixtures (Böhme, 1990) were fed to early-weaned pigs. In broilers, supplementary enzymes reduce the viscosity of the small intestinal chyme (Bedford and Classen, 1992), thereby improving nutrient digestibility and absorption (Almirall et al., 1993). A similar, but apparently weaker, relationship appears to exist also in young pigs (Bedford et al., (1992). In the present experiment, using the same technique as in the last cited experiments, enzyme supplementation reduced digesta viscosity in the stomach and small intestine. This is in agreement with the previously reported results and suggests a similar enzyme mode of action of supplementary $\beta$-glucanase in the young pig as in broilers fed viscous polysaccharides. The reduction of the viscosity coincided with a dramatic increase in $\beta$-glucan digestibility, suggesting that this component was an important contributor to the intestinal viscosity. This effect on the $\beta$-glucans are in agreement with the results reported by Graham et al. (1989) when a barley-based diet was fed to finishing pigs. However, the level of viscosity and magnitude of the reduction due to enzyme supplementation in the present experiment were considerably lower than that reported in broiler chickens (Inborr and Bedford, 1993). This, in combination with a relatively low number of observations, may explain why no significant correlation was found between reduced gut viscosity and improved feed utilisation (data not shown). However, it has recently been shown that in broiler chickens the relative reduction of gut viscosity due to enzyme supplementation is more important than the absolute value (Graham and Bedford, 1993). Consequently, a 50\% reduction at any level of viscosity should result in a performance improvement of similar magnitude. If this relationship is valid also in the pig, the reduction in small intestinal viscosity observed in the present experiment should translate into an improved performance. The improved live weight gain and feed utilisation observed in the present experiment would support this.

Increasing gut viscosity by feeding viscous polysaccharides such as guar gum has been shown to increase the output of pancreatic juice and enzyme activities (Ikegami et al., 1990). In the present experiment, $\beta$-glucanase supplementation generally reduced the amount of the digestive enzymes in the first three quarters of the small intestine. With Condor barley creating a more viscous environment, this effect was particularly evident. Among the enzymes monitored, amylase was the one that seemed most affected by the $\beta$-glucanase. 
However, starch digestibility was not reduced, which suggests that there was sufficient starch degrading activity despite the considerably lower amylase concentration. Corring (1982) reported that a pig of $50 \mathrm{~kg}$ live weight produced enough amylase to hydrolyse $30 \mathrm{~kg}$ of soluble starch daily. It, therefore, seems unlikely that even a considerable reduction of amylase production would reduce starch digestibility, in particular, if more optimal conditions for enzymatic hydrolysis are concomitantly being created. Leclerce et al. (1993) reported reduced starch digestibilities in jejunum and ileum of pigs fed diets with increasing amounts of viscous guar gum. Interestingly, these workers reported reduced amylase activity in the small intestine when more viscous guar gums were used. This is in contrast with the results of the present and other experiments (Ikegami et al., 1990; Cherbut et al., 1990). Increased viscosity has been shown to reduce the rate of nutrient diffusion in-vitro (Fengler and Marquardt, 1988) and to reduce nutrient digestibility in broiler chickens (Choct \& Annison, 1992). Consequently, one can assume that by reducing intestinal viscosity less digestive enzymes are required to achieve the same rate of digestion as in a more viscous environment. This assumption is supported by the results obtained in this experiment, with no reduction in nutrient digestibility despite on average 20 per cent less digestive enzyme activities. In fact, protein digestibility tended to be improved due to the addition of the enzyme. Bedford et al. (1992) observed a significantly higher protein digestiblity over the whole small intestine of early-weaned pigs when a barley-based diet was supplemented with $\beta$-glucanase. They assumed this effect being mainly related to improved utilisation of the dietary protein. The results from the present experiment would suggest that a reduction in the production of digestive enzymes is also contributing to the increased protein digestibility. The energy saved by the reduced production of digestive enzymes is thus potentially available to increase the efficiency of nutrient assimilation and improve growth performance and feed utilisation. Again, the observed significant improvement in live weight gain and feed utilisation due to enzyme addition would support this assumption. The daily exocrine pancreatic protein output has been estimated to between 2 and $6 \mathrm{~g}$ in pigs during the weeks following weaning (Pierzynowski, 1991), whereas in older pigs values between 9 and $25 \mathrm{~g}$ have been reported (Souffrant, 1991). Assuming $10 \mathrm{~g}$ daily protein output in digestive enzyme production (including intestinal amylase) in the pigs of the present experiment a 20 per cent reduction would mean $2 \mathrm{~g}$ less protein required for the digestive enzymes. This represents approximately 5 per cent of the daily protein retention of pigs growing at a similar 
rate as the pigs in the present study (Lassota, 1987), which would then be availvable for lean growth. Conversely, this could lead to a more efficient utilisation of dietary energy and protein, resulting in an improved feed utilisation.

In conclusion, enzyme supplementation significantly reduced digesta viscosity in the small intestine and reduced the concentration of digestive enzymes without affecting nutrient digestibility. It appears that conditions for a more energy efficient digestion were brought about by the addition of the $\beta$-glucanase, reducing endogenous losses and leading to increased weight gain and improved feed utilisation.

\section{ACKNOWLEDGEMENTS}

This experiment was carried out at the National Institute of Animal Science (NIAS), Department of Animal Physiology and Biochemistry, Research Centre Foulum, Denmark under the supervision of Dr Kirsten Jakobsen and Ms Mette Skou Jensen. Their assistance and the technical support of Dr K.E. Bach Knudsen and Dr B. Borg Jensen are highly appreciated. The experiment was funded by NIAS and Finnfeeds International Ltd., Marlborough, United Kingdom. 


\section{REFERENCES}

Åman, P \& Graham, H. (1987). Analysis of total and insoluble mixed-linked (1-3),(1-4)- $\beta$-D glucans in barley and oats. Journal of Agricultural Food Chemistry 35, 704-709.

Association of Official Analytical Chemists (1975). Official Methods of Analysis. 11th ed. Washington D.C.: Association of Official Analytical Chemists.

Bach Knudsen, K.E., Åman, P \& Eggum, B.O. (1987). Nutritive value of danish-grown barley varities, I, Carbohydrates and other major constituents. Journal of Cereal Science 6, 173-186.

Bathgate, G.N. (1987). The determination of endo- $\beta$-glucanase activity in malt. Journal of the Institute of Brewing 85, 92-94.

Bedford, M.R. \& Classen, H.L. (1992). Reduction of intestinal viscosity through manipulation of dietary rye and pentosanase concentration is effected through changes in the carbohydrate composition of the intestinal aqueous phase and results in improved growth rate and feed conversion. Journal of Nutrition 122, 560-569.

Bedford, M.R., Classen, H.L., Patience, J.F. \& Inborr, J. (1992). Effect of dietary enzyme supplementation of rye- and barley-based diets on digestion and subsequent performance in pigs. Canadian Journal of Animal Science 72, 97-105.

Boisen, S., Andersen, C. Y. \& Hejgaard, J. (1981). Inhibitors of chymotrypsin and microbial serine proteases in barley grains. Physiology of Plants 52, 167-176.

Böhme, H. (1990). Experiments on the effect of enzyme supplements as a growth promotor for piglets. Landbauforschung Völkenrode 40, 213-217.

Cherbut, C., Albina, E., Champ, M., Doublier, J.L. \& Lecannu, G. (1990). Action of guar gums on the viscosity of digestive contents and on the gastrointestinal motor function in pigs. Digestion 46, 205-213.

Choct, M. \& Annison, G. (1992). Anti-nutritive effect of wheat pentosans in broiler chickens: roles of viscosity and gut microflora. British Poultry Science 33, 821-834.

Corring, T. (1982). Enzyme digestion in the proximal digestive tract of the pig: A review. Livestock Production Science 9, 581-590.

Erlanger, B.F., Kokowsky, N. \& Cohen, W. (1961). the preparation and properties of two new chromogenic substrates of trypsin. Archive of Biochemical Biophysiology 95, 271-278.

Erlanger, B.F., Edel, F. \& Cooper, A.G. (1966). the action of chymotrypsin on two chromogenic substrates of trypsin. Archive of biochemical Boiphysiology 115, 206-210. 
Erlanson-Albertsson, C., Larsson, A \& Duan, R. (1987). Secretion of pancreatic lipase and colipase from rat pancreas. Pancreas 2, 531-535.

Fengler, A.S. \& Marquardt, R.R. (1988). Water-soluble pentosans from rye: II. Effects on rate of dialysis and on the retention of nutrients by the chick. Cereal Chemistry 65, 298-302.

Furuya, S. \& Kaji, Y. (1991). Additivity of the apparent and true ileal digestible amino acid supply in barley, maize and wheat or soya-bean meal based diets for growing pigs. Animal Feed Science and Technology 32, 321-331.

Graham, H. (1988). Dietary fibre concentration and assimilation in swine. ISI Atlas of Science: Animal and Plant Sciences 1, 76-80.

Graham, H. \& Bedford, M.R. (1993). Feed enzymes: Mode of action and application to heat processed poultry feeds. Amandus Kahl Seminar, EUROTIER, Hannover, Germany. Manuscript, pp.12.

Graham, H., Åman, P. and Löwgren, W. (1988). Enzyme supplementation of pig diets. In Proceedings of the 4th International seminar on Digestive physiology in the pig, pp 371-376 [L. Buraczewska, S. Buraczewski, B. Pastuszewska and T. Zebrowska, editors]. Jablonna, Polish Academy of Sciences.

Graham, H., Fadel, J.G., Newman, C.W. \& Newman, R. K. (1989). Effect of pelleting and $\beta$-glucanase supplementation on the ileal and fecal digestibility of a barley-based diet in the pig. Journal of Animal Science 67, 1293-1298.

Hesselman, K. (1983). PhD Thesis. Swedish University of Agricultural Sciences, Uppsala.

Hesselman, K. \& Thomke, S. (1982). Influence of some factors on development of viscosity in the water-extract of barley. Swedish Journal of Agricultural Research 12, 17-22.

Ikegami, S., Tsuchihashi, F., Harada, H., Tsuchihashi, N., Nishide, E. \& Innami, S. (1990). Effect of viscous indigestible polysaccharides on pancreatic-biliary secretion and digestive organs in rats. Journal of Nutrition 120, 353-360.

Inborr, J. \& Bedford, M.R. (1993). Stability of feed enzymes to steam pelleting during feed processing. Animal Feed Science and Technology. (In press).

Inborr, J. \& Grönlund, A. (1993). Stability of feed enzymes in physiological conditions assayed by in-vitro methods. Agricultural Science in Finland 2, 125-132.

Inborr, J., Bedford, M.R. \& Graham, H. (1993). Stability and mode of action of poultry feed enzymes in diets based on wheat and barley. In Proceedings of the Australian Poultry Science Symposium, Vol. 5, 53-56. University of Sydney, Sydney, February.

Inborr, J., Schmitz, M. \& Ahrens, F. (1993). Effect of adding fibre and starch degrading enzymes to a barley/wheat-based diet on performance and nutrient digestibility in different segments of the small intestine of early weaned pigs. Animal Feed Science and Technology 44, 113-127. 
Lassota, L. (1988). The efficiency of nitrogen utilisation in very early weaned pigs. In Proceedings of the 5th International Symposium on Protein Metabolism and Nutrition [Wissenschaftliche Zeitschrift der Wilhelm-Pieck-Universität, Rostock], EAAP publication No. 35, pp. 67.

Lawrence, T.L.J. (1972). High level cereal diets for the growing/finishing pig. VI. An evaluation of flaked maize, wheat and barley when included at high levels in the diet of the weaned pig grown to cutter weight $(160 \mathrm{lb})$. Journal of Agricultural Science, Cambridge, 79, 155-160.

Lawrence, T.L.J. (1973). An evaluation of the micronization process for preparing cereals for the growing pig. 2. Effects on growth rate, food conversion efficiency and carcass characteristics. Animal Production 16, 109-116.

Leclerce, C., Champ, M., Cherbut, C. \& Delort-Laval, J. 1993. Starch digestion and amylase activity in the small intestine in the presence of guar gums. Sciences des aliments, 13, 325-332.

Low, A.G. (1985). The role of dietary fibre in digestion, absorption and metabolism. In Proceedings of the 3rd International Seminar on Digestive physiology in the Pig, pp 157-179 [A. Just, J. Fernandez and H. Jorgensen, editors]. Copenhagen: National Institute of Animal Science. pp. 157-179.

Markström, B., Pettersson, D. \& Hesselman, K. (1985). $\beta$-glukanastillsats till grov- och finmalet korn - ett smältbarhetsförsök med smågrisar. Sveriges Lantbruksuniversitet, Inst. för husdjurens utfodring och vård. Rapport 149. Swedish University of Agricultural Sciences, Uppsala.

McConnell, J.C., Skelley, G.C., Handlin, D.L. \& Johnston, W.E. (1975). Corn, wheat, milo and barley with soybean meal or roasted soybeans and their effect on feed lot performance, carcass traits and pork acceptability. Journal of Animal Science 41, 1021-1030.

Meyer, J.H., Gu, Y., Elashoff, J., Reedy, T., Dressman, J. \& Amidon, G. (1986). Effects of viscosity and fluid outflow on postcibal gastric emptying of solids. American Journal of Physiology 250, G161-G164.

McCleary, B.V. \& Glennie-Holmes, M. (1985). Enzymic quantification of (1-3),(1-4)- $\beta$-Dglucan in barley and malt. Journal of the Institute of Brewing 91, 285-295.

Pierzynowski, S. (1991). Development and regulation of porcine pancreatic function with special reference to the exocrine pancreas. PhD Thesis, University of Lund, Sweden.

Rainbird, A.L. \& Low, A.G. (1986). Effect of various dietary fibres on gastric emptying of growing pigs. British Journal of Nutrition 55, 111-121.

Statistical Analysis System Institute, Inc. (1982). SAS user's guide: Statistics. SAS Inst., Inc. Cary, NC. 
Schürch, A., Lloyd, L. \& Crapton, E.W. (1950). The use of Chromic oxide as an index for determining the digestibility of a diet. Journal of Nutrition 50, 629-636.

Souffrant, W.B. (1991). Endogenous nitrogen losses during digestion in pigs. In Proceedings of the Vth International Symposium on Digestive Physiology in Pigs, pp 147-167 [M.W.A. Verstegen, J. Huisman and L.A. den Hartog, editors]. EAAP publication No. 54. Pudoc, Wageningen.

Stoldt, W. (1957). Vorschlag zur Vereinheitlichung der Fettbestimmung in Lebensmitteln. Fette, Seifen, Anstrichmittel 54. 206-207.

Thomke, S., Rundgren, M. \& Hesselman, K (1980). The effect of feeding high-viscosity barley to pigs. In Proceedings of the 31st annual meeting of the European Association of Animal Production, Munich, Germany. Commission on Animal Nutrition. pp 5.

White, W.B., Bird, H.R., Sunde, M.L., Prentice, N., Burger, W.C. \& Martlett, J.A. (1981). The viscosity interaction of barley beta-glucan with Trichoderma viride cellulase in the chick intestine. Poultry Science 60, 1043-1048. 